UNIVERSIDADE DE SÃO PAULO

INSTITUTO DE GEOCIÊNCIAS

\title{
RELAÇÕES ENTRE AS ESTRUTURAS TECTÔNICAS, SEDIMENTAÇÃO COLUVIAL E GEOMORFOGÊNESE DA REGIÃO DE MANAUS, AMAZONAS
}

\author{
Roseane Ribeiro Sarges
}

Orientador: Prof. Dr. Claudio Riccomini

TESE DE DOUTORAMENTO

Programa de Pós-Graduação em Geoquímica e Geotectônica

SÃO PAULO

2007 
Ficha catalográfica preparada pelo Serviço de Biblioteca e Documentação do Instituto de Geociências da Universidade de São Paulo

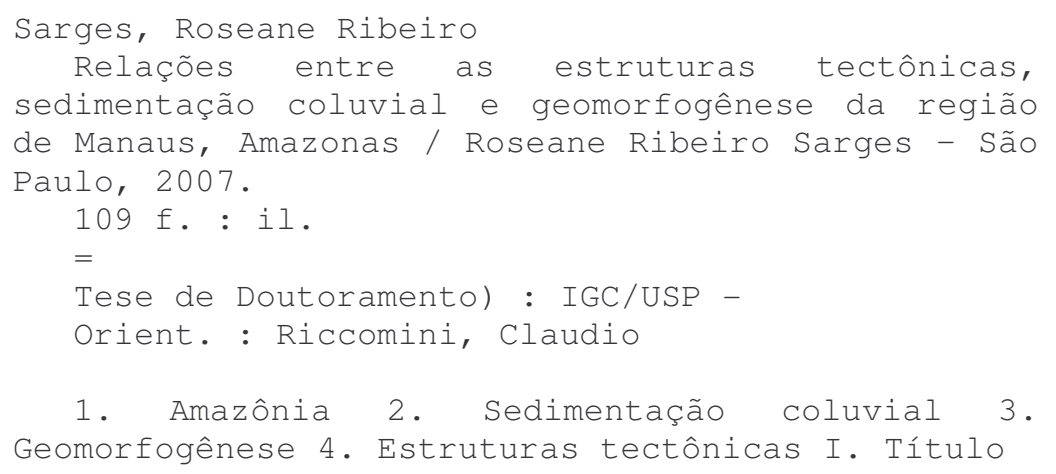




\section{AGRADECIMENTOS}

Presto agradecimentos àqueles cujas participações foram de grande importância na realização desta pesquisa:

- Ao Curso de Pós-Graduação em Geoquímica e Geotectônica do Instituto de Geociências da Universidade de São Paulo. 02/09564-0).

- À FAPESP, pelo financiamento desta pesquisa através da concessão de bolsa DR (Processo

- Ao Prof. Dr. Claudio Riccomini pela orientação e oportunas críticas e sugestões.

- À CPRM/Sureg MA, pelo apoio logístico recebido na realização do levantamento ao longo dos rios Negro e Cuieiras, sobretudo a Daniel Nava (Superintendente), Marco Antonio de Oliveira (Gerente de Hidrologia) e Daniel de Oliveira. Um agradecimento muito especial para minha grande amiga e geóloga Nailde Martins Andrade, pelo valioso auxílio, presteza e contribuição fundamental na realização de várias etapas de levantamento fluvial e levantamento terrestre. Gostaria também de agradecer à tripulação do barco Comandante Caxias: Sr. Iran, Michel, D. Elza e Sr. Dominguinhos.

- À UFAM, pelo apoio na realização das atividades de campo, em especial a Francisco das Chagas (Chefe da Divisão de Serviços), Walklin Ferreira e Gilberto Nascimento (motoristas).

- Ao Dr. Márcio de Morrisson Valeriano (INPE), pelas discussões e sugestões; ao MSc. Gilberto Kaulfuss, pelas discussões em geoprocessamento e sugestões; ao MSc. Paulo Roberto Alves dos Santos (IBGE), pelas discussões sobre os aspectos cartográficos e ao MSc. Rafael Barros (IBGE), pelas discussões sobre correção de dados do SRTM, e ao Dr. Jackson Paz pela leitura, discussões, sugestões e críticas ao texto.

- Ao geólogo Izaías Nascimento dos Santos (Só Poços S/A), pelo inestimável apoio nas atividades de campo, discussões sobre a geologia da região de Manaus e pela amizade de muitos anos.

- À Humberto Abinader, Roberto César Mendonça, Hozerlan Silva e Joelson Soares pelo apoio na etapa de coleta de dados de campo.

- Aos funcionários do Instituto de Geociências - USP: Ana Paula Cabanal e Magali Rizzo (Secretaria); Erickson Zanon (Informática); Paulinho (Almoxarifado); Aline, Brenda, Érica, Maria e Neusa (Biblioteca); Claudionor, Henrique, José e Edmir (Setor de gráfica e reprografia); José Carlos e Wagner (Visual); Reynaldo (Cuca) e Tadeu (Apoio Acadêmico).

- Às queridas amigas da Uapgeo, que convivem (ram) no meu dia a dia, em especial: a conselheira Cintia Gaia (Cídia), a meiga Paula Amaral (Pizinha), a solidária Silvia Cremonez (Silva), a destemida Aline Silverol, a otimista Deborah Mendes, a sempre coerente e exemplo de persistência Lucelene Martins e a iluminada Márcia Gomes.

Tive o prazer de conhecer, ao longo do doutorado, pessoas muito especiais que deixaram saudades: Alejandro Salazar, Agustin Cardona, Celi Zanon, Claudia Moura, Claudia Varnier, Cristiano Chiessi, Gaston Enrich, Ivanety Anjos, José Coelho, minha querida amiga Josiane Silva, Juli, Leandro Donatti, Luís Macedo, Marcos Mondin, Marta Velasquez, Milene Figueiredo, Ramiro Gerardo, Rogério, Simone Gióia, Valéria Guimarães e Veridiana Martins.

Um agradecimento especial à Germaine Martins de Souza, pelo valioso auxílio na realização deste trabalho e pela inestimável amizade de muitos anos.

Aos meus pais, irmãos, sobrinhos (inclusive os postiços), cunhados e queridos amigos que estão espalhados pelo mundo afora. Mesmo distantes vocês sempre me deram carinho, força e incentivo: eu não teria chegado até aqui sem o apoio de vocês!

Enfim, estendo meus agradecimentos a todos que contribuíram na realização deste trabalho. 


\section{RESUMO}

O relevo da região de Manaus, porção nordeste do Estado do Amazonas, constitui um excelente exemplo de modificação de paisagem. Localizada entre dois rios de grande porte, o Negro e o Amazonas, esta região foi palco de eventos de denudação e movimentações tectônicas que ocorreram desde o final do Cretáceo. Parte da sedimentação resultante da atuação de processos denudacionais na região está documentada pelos depósitos coluviais, que foram subdivididos em quatro tipos, denominados DCA, DCB, DCC e DCD, com base na litologia e constituição dos litoclastos presentes. O DCA é constituído por cascalhos maciços sustentados pela matriz (fácies $\mathrm{Cmsm}$ ), cascalhos maciços sustentados por clastos (fácies $\mathrm{Cmsc}$ ) e areias maciças (fácies Am). O DCB consiste em cascalhos maciços com seixos de lamitos semi-flint (fácies Cmsf). O DCC compreende cascalhos maciços sustentados pela matriz (fácies $\mathrm{Cmsm}$ ) e cascalhos finos com gradação inversa (fácies Cgi). Finalmente, o DCD corresponde a cascalhos maciços sustentados pela matriz (fácies $\mathrm{Cmsm}$ ) ou por clastos (fácies Cmsc) e cascalhos com gradação inversa (fácies Cgi). Estes depósitos foram formados em múltiplos eventos de coluviação que ocorreram provavelmente desde o Plioceno-Pleistoceno, sob influência de pulsos tectônicos. Os processos denudacionais associados a movimentos tectônicos foram responsáveis pela geração de suprimento sedimentar e construção do modelado, resultando na erosão e pediplanação das rochas sedimentares da borda norte da Bacia do Amazonas. O relevo resultante é caracterizado por terraços fluviais, terraços erosivos, vales, planícies de inundação, divisores dissecados com topo agudo e divisores tabulares com topo côncavo a plano, com baixos ângulos de declividades (em média $8^{\circ}$ ). Estas feições geomórficas estão distribuídas nos compartimentos topográficos $\Delta \mathrm{h}<50 \mathrm{~m}, \Delta \mathrm{h}=75 \mathrm{~m}$ e $\Delta \mathrm{h}>100 \mathrm{~m}$. O compartimento $\Delta \mathrm{h}<50 \mathrm{~m}$ compreende as áreas de acumulações fluviais distribuídas ao longo dos rios Amazonas, Negro, Cuieiras, Tarumã Mirim, Tarumã Açu, Puraquequara e Preto da Eva. Os compartimentos $\Delta \mathrm{h}=75 \mathrm{~m}$, que ocorre na região do rio Cuieiras, e $\Delta \mathrm{h}>100 \mathrm{~m}$, que compreende a área entre os rios Tarumã Mirim e Preto da Eva, correspondem às áreas de ocorrência de divisores tabulares com diferentes graus de dissecação. Falhas normais sinsedimentares resultantes de esforços distensivos N-S que afetam a Formação Alter do Chão indicam que pulsos de movimentações tectônicas têm atuado na região desde o final do Cretáceo. Subseqüentemente, vigorou uma distensão radial, registrada por falhas e fraturas nos depósitos pós-cretáceos. A última fase está representada por esforços distensivos E-W, com falhas e fraturas que afetam perfis lateríticos imaturos e sedimentos quaternários. Estes movimentos tectônicos estão refletidos no relevo como inflexões abruptas ou segmentos retilíneos nos canais de drenagem, desembocaduras afogadas e alinhamentos de feições geomórficas. Os esforços tectônicos foram responsáveis por duas reorganizações na rede de drenagem, que imprimiram importantes modificações na paisagem da área. A primeira reorganização, miocena, está representada pelo paralelelismo dos rios Tarumã Mirim, Tarumã Açu, Puraquequara e Preto da Eva, tributários dos rios Negro e Amazonas, e associado à reversão do fluxo do rio Amazonas de oeste para leste, conforme o modelo proposto para a região. A segunda, de abrangência local e registrada na parte no oeste da área, imprimiu inflexões anômalas em trechos do canal do rio Cuieiras, promoveu capturas de drenagens e está associada à formação do compartimento $\Delta \mathrm{h}=75 \mathrm{~m}$. Esta modificação local da rede de drenagem está relacionada à distensão radial pós-cretáceo. 


\begin{abstract}
The landforms of the Manaus region, northeastern State of Amazonas, constitute an excellent example of the modification of landscape. This region is located between two large rivers, the Negro and the Amazonas, and has been subjected to denudation and tectonic events that occurred since the late Cretaceous and are the main mechanism for shaping the landscape of the Manaus region. Sedimentation and denudation in the region are recorded by colluvial deposits which are subdivided into four classes (DCA, DCB, DCC and DCD), based on their facies characteristics (mainly lithology) and composition of lithoclasts. The DCA consists of massive matrix-supported gravels (facies Cmsm), massive clast-supported gravels (facies Cmsc) and massive sands (facies Am). The DCB are characterized by gravels with semi-flint mudstone pebbles (facies Cmsf). The DCC consists of massive matrix-supported gravels (facies $\mathrm{Cmsm}$ ) and fine gravels with inverse grading (facies Cgi). Finally, the DCD consists of massive matrix-supported gravels (facies $\mathrm{Cmsm}$ ), or alternatively massive clast-supported gravels (facies $\mathrm{Cmsc}$ ) and gravels with inverse grading (facies Cgi). The origin of these deposits has been attributed to various episodes of colluviation that likely occurred in the Pliocene or Pleistocene. The denudation and tectonic events generated sedimentary supply and sculpted the relief, leading to the erosion and pediplanation of sedimentary rocks in the studied region. The relief is characterized by fluvial and erosional terraces, valleys, floodplains, dissected divides (acute to tabular tops) and low declivities (averaging $8^{\circ}$ ). These geomorphic features are distributed in three topographical domains, $\Delta \mathrm{h}<50 \mathrm{~m}, \Delta \mathrm{h}=75 \mathrm{~m}$ and $\Delta \mathrm{h}>100 \mathrm{~m}$. Topographical domain $\Delta \mathrm{h}>100 \mathrm{~m}$, which corresponding to the area between the Tarumã Mirim and Preto da Eva rivers, is a tabularshaped divide with varying degrees of dissection. Synsedimentary normal faults in the Alter do Chão Formation, attributed to an extensional N-S trending stress-field, indicate tectonic activity since the deposition of this Cretaceous formation. Subsequent tectonic pulses are related to a radial extensional regime that affected post-Cretaceous deposits. This was followed by an another extensional E-W trending regime that affected the immature lateritic profiles and Quaternary sediments. The tectonic events caused drainage anomalies, alignments of geomorphic features, reorganization of drainage networks and also imposed important modifications on the landscape in the region. The drainage anomalies include sharp inflections in drainage channels, rectilinear drainage segments and dammed channels. Two main landscape modifications took place: the first one is represented by the parallel configuration of the Tarumã Mirim, Tarumã Açu, Puraquequara and Preto da Eva rivers which are tributaries of the Negro-Amazonas river system, and the second one, a local readaptation of segments of the Cuieiras river. In addition, this later reorganization caused anomalous inflections and captures in the Cuieiras river channel and is associated with the formation of the topographical domain $\Delta \mathrm{h}=75 \mathrm{~m}$. This event was attributed to tectonics related to the radial extension.
\end{abstract}




\section{SUMÁRIO}

AGRADECIMENTOS__ i

RESUMO _ iii

ABSTRACT_ iii

SUMÁRIO_ iv

LISTA DE FIGURAS__ v

LISTA DE TABELAS__

1. INTRODUÇÃO 1

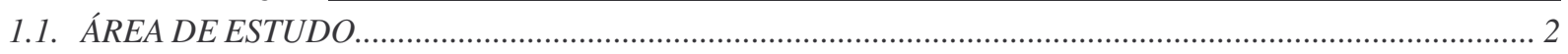

1.2. OBJETIVOS

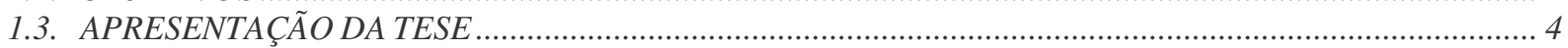

2. MATERIAIS E MÉTODOS__

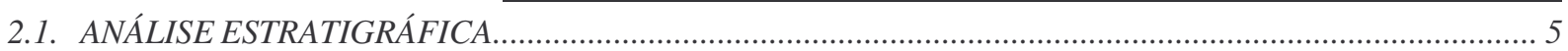

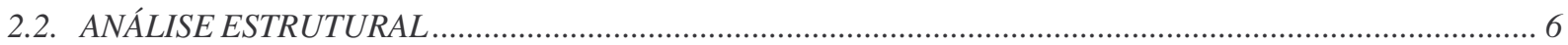

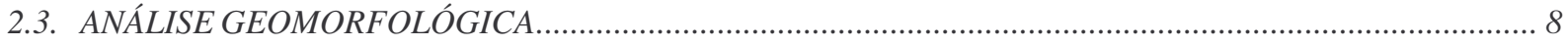

3. ASPECTOS GEOLÓGICOS

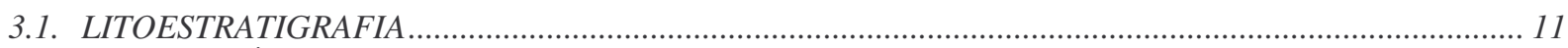

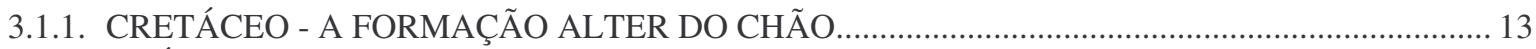

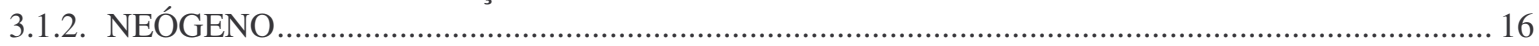

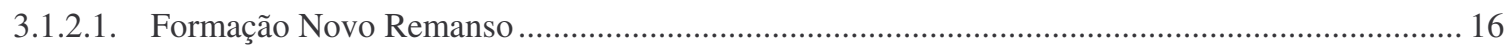

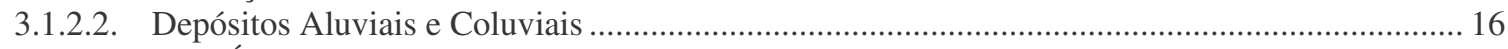

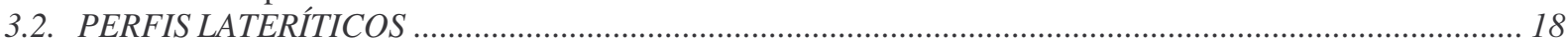

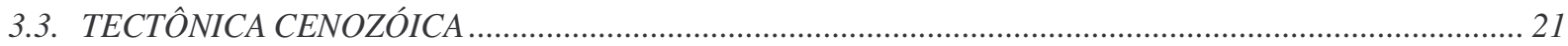

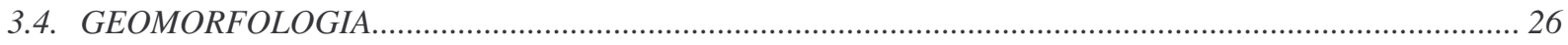

4. DEPÓSITOS SEDIMENTARES DA REGIÃO DE MANAUS_

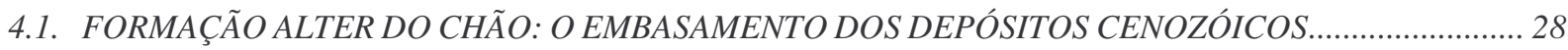

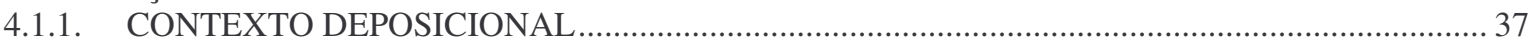

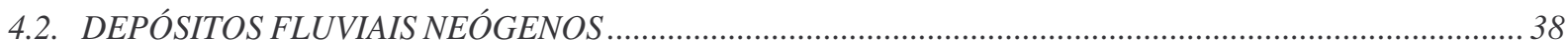

4.3. A GÊNESE DOS DEPÓSITOS COLUVIAIS NA REGIÃO DE MANAUS, NORDESTE DO ESTADO DO

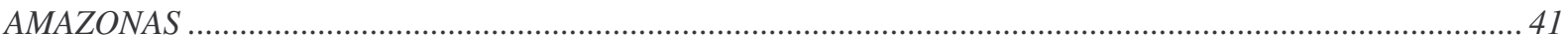

5. CARACTERIZAÇÃo DO RELEVO DA REGIÃO DE MANAUS, AMAZÔNIA CENTRAL___

6. A INFLUÊNCIA DA TECTÔNICA MESOZÓICA-CENOZÓICA NA PAISAGEM DE MANAUS, AMAZONAS_ $\mathbf{8 3}$

6.1. SÍNTESE DO QUADRO TECTÔNICO CENOZÓICO DA REGIÃO DE MANAUS ………........................... 85

6.2. REGIMES DE ESFORÇOS ATUANTES NA PORÇÃO NORTE DA PLACA SUL-AMERICANA ................86

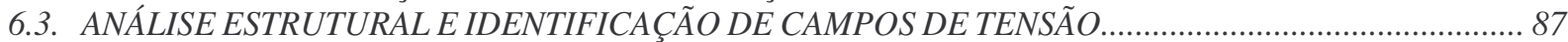

6.3.1. ESTRUTURAS IDENTIFICADAS E SUAS RELAÇÕES COM AS UNIDADES

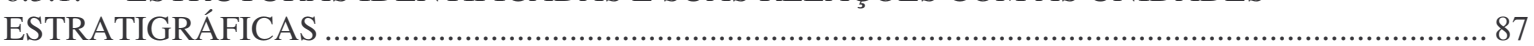

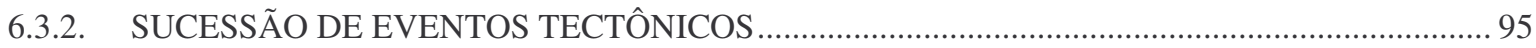

7. INTEGRAÇÃO DOS RESULTADOS__

8. CONCLUSÕES $\quad 98$

REFERÊNCIAIS BIBLIOGRÁFICAS 


\section{LISTA DE FIGURAS}

Figura 1.1: Localização da área de estudo (destacada em branco na imagem de satélite), situada nos municípios de Manaus e Rio Preto da Eva, com representação das cartas topográficas que recobrem a região. Na imagem de satélite, as áreas urbanas estão destacadas pela cor rosa.

Figura 2.1: Esquema ilustrativo do método dos diedros retos proposto por Angelier \& Mechler (1977). A) Representação em bloco-diagrama das relações angulares entre o plano de falha com estrias e o plano auxiliar. B) Projeção estereográfica. C) Representação da aplicação do método, identificando os campos de compressão (hachura diagonal), extensão (em branco) e as zonas de compatibilidade (hachura quadriculada). Esta última é identificada através da superposição destes campos (fonte: Mello 1997).

Figura 2.2: Modelo Digital de Elevação (MDE) da região de Manaus (USGS 2003), com correção de vazios altimétricos e de cotas negativas.

Figura 3.1: Parte superior da carta estratigráfica da Bacia do Amazonas (adaptado de Cunha et al. 1994), representada pelas formações Solimões e Alter do Chão. Foram adicionadas as unidades cenozóicas sobrepostas à bacia, constituídas pela Formação Içá (cf. Maia et al. 1977), Formação Novo Remanso e Depósitos aluviais quaternários ( $c f$. Rozo et al. 2006).

Figura 3.2: Aspectos geológicos e geomorfológicos da região de Manaus. A) Distribuição das unidades geológicas no estado do Amazonas e na área de estudo (adaptado de UFAM $2004 \mathrm{e}$ Nogueira et al. 2006). B) Distribuição dos domínios geomorfológicos Planalto Dissecado Rio Trombetas-Rio Negro e Planície Amazônica sobre o MDE, segundo Nascimento et al. (1976) e Costa et al. (1978).

Figura 3.3: Exposição representativa dos depósitos sedimentares relacionados à sedimentação coluvial da região de Manaus, segundo Meis (1971). Ressalta-se que a unidade considerada como "Barreiras" corresponde à Formação Alter do Chão. O estrato 8 corresponde aos oxissolos amarelos.

Figura 3.4: Esboço da evolução morfológica entre as regiões de Presidente Figueiredo e Manaus (modificado de Horbe et al. 2001): 1) Deposição da Formação Alter do Chão (Cretáceo) e lateritização da Formação Nhamundá; 2) Soerguimento e aplainamento da Formação Alter do Chão; 3) Dissecação da SA1 e início da lateritização da Formação Alter do Chão, com superposição de processos lateríticos; 4) Formação da SA2, geração do horizonte aluminoso sobre a Formação Alter do Chão, denudação da SA1 e formação de depósitos coluviais; 5) Lateritização incipiente, dissecação atual e configuração do relevo.

Figura 4.1: Afloramento da Formação Alter do Chão, com empilhamento sedimentar mais completo na área de estudo, localizado às margens do rio Negro, zona sul de Manaus. A) Vista panorâmica do afloramento MN-51-04, com situação da seção estratigráfica no lado 1, delineada pela linha em preto. B) Aspecto geral da seção do lado 1, e a reconstituição estratigráfica interpretada e situação dos perfis litoestratigráficos. Destacam-se a geometria das camadas e a superfície de descontinuidade S1. Foram interpretadas camadas apresentando geometria de canal fluvial. Observam-se falhas de componentes normais e lístricas desnivelando as camadas.

Figura 4.2: Afloramento da Formação Alter do Chão, localizado às margens do rio Negro, zona sul de Manaus. A) Vista panorâmica do afloramento MN-51-04, com localização do detalhe em B. B) Aspecto geral da sucessão 1 e a localização dos perfis, na seção estratigráfica do Lado 2. C) Perfis litoestratigráficos da sucessão 1 .

Figura 4.3: Afloramento da Formação Alter do Chão, localizado às margens do rio Negro, ao sul de Manaus. A) Vista panorâmica do afloramento MN-51-04. B) Contato entre a sucessão 1 e a sucessão 2, na seção estratigráfica do Lado 1, e a localização dos perfis. C) Perfis litoestratigráficos: o Perfil 1 pertence à sucessão 1 e o Perfil 2 é representativo da sucessão 2 ......32 
Figura 4.4: Afloramento da Formação Alter do Chão (MN-51-04), localizado às margens do rio Negro, ao sul de Manaus. A) Localização dos perfis na secção estratigráfica do lado 1. B) Perfis litoestratigráficos representativos da sucessão 2 .

Figura 4.5: Afloramento da Formação Alter do Chão, localizado às margens do rio Negro, zona sul de Manaus. A) Vista panorâmica do afloramento MN-51-04, com situação da seção estratigráfia do lado 2, delineada pela linha em amarelo. B) Desenho esquemático da seção estratigráfica do lado 2 e localização da foto de detalhe. C) Aspecto geral do topo da sucessão 2, com deformação das camadas. . D) Perfil litoestratigráfico do topo da sucessão 2, que apresenta linha de pedra formada por nódulos ferruginosos e solo tipo oxissolo.

Figura 4.6: Seção estratigráfica MN-02-05, localizada à margem esquerda do rio Negro. A) Vista geral do afloramento, com representação da seção. Destaca-se a superfície de descontinuidade S2, que limita um pacote de arenitos bem silicificados avermelhados, com fraturas subverticais, da sucessão sedimentar superior do afloramento, que pode constituir uma unidade diferenciada da Formação Alter do Chão, provavelmente paleógena. B) Observam-se três níveis de terraços erosivos T1, T2 e T3, cuja relação morfoestratigráfica indica que T3 é o mais recente; T2 é o intermediário e T1 corresponde ao nível mais antigo. C) do topo da seção, constituído por sedimentos fluviais síltico-argilosos provavelmente holocenos, representando os depósitos mais novos da área. D) Aspecto geral do contato entre os arenitos médios avermelhados e o pacote sedimentar intermediário. E) Detalhe do pacote intermediário constituído por arenitos grossos a médios, maciços, com intensa bioturbação, apresentando uma lâmina de arenito ferruginizado entre o pacote sedimentar. F). Fraturas subverticais observadas em planta, desenvolvidas somente nos arenitos avermelhados.

Figura 4.7: Seção estratigráfica MN-03-05. A) Vista panorâmica do afloramento. B) Afloramento apresentando camadas basais de arenitos, siltitos e argilitos avermelhados pertencentes à Formação Alter do Chão. Uma superfície de descontinuidade limita o pacote sedimentar superior, constituído por arenitos médios de coloração alaranjada. C) Perfil estratigráfico representativo da seção, com depósito coluvial desenvolvido no topo.

Figura 4.8: Formas de relevo associadas aos depósitos aluviais da região. A) Vale colmatado (1), registrado na zona leste de Manaus. B) Desembocadura do igarapé São Raimundo, onde se observa planície de inundação atual influenciada pela dinâmica fluvial do rio Negro (2). C) Margem esquerda do rio Negro, no extremo sudeste de Manaus, com exemplos de terraço fluvial (3), com altura média de $2 \mathrm{~m}$, e planície de inundação atual (2). D) Lago do Puraquequara, com planície de inundação atual (2). E) Planície de inundação atual (2) em rio tributário da margem esquerda do rio Solimões.

Figura 4.9: Depósitos sedimentares arenosos que configuram terraços fluviais ao longo do rio Cueiras. A) Aspecto geral da exposição, com disposição subhorizontal das camadas de arenitos. B) Detalhe do afloramento, onde se observa nível delgado rico em matéria orgânica, intercalado com arenitos (MN-P1-05).

Figura 4.10: Seção estratigráfica MN-06-05, que representa duas unidades neógenas ocorrentes no rio Cuieiras. A) Vista geral da seção, localizada em um divisor às margens do rio, com depressões em "U" escavadas no pacote sedimentar de coloração avermelhada constituído por areias finas a siltes; este encontra-se preenchido por camadas horizontais de arenitos médios de coloração branco-acinzentado, com grânulos de quartzo. B) Contato entre as areias finas a siltes vermelhas e os arenitos médios branco-acinzentado. C) Detalhe da base da depressão preenchida por arenitos branco-acinzentados. D) Canal de um tributário do rio Cuieiras, com vale em forma de "U", que fica totalmente exposto no período de vazante.

Figura 4.11: Situação da área de estudo, compreendida entre as cidades de Manaus e Presidente Figueiredo, nordeste do estado do Amazonas. As indicações numeradas ao longo da área representam os afloramentos dos depósitos coluviais estudados. 
Figura 4.12: Exemplo da sucessão sedimentar característica do DCA. A) Seção panorâmica do afloramento P4, localizado na rodovia BR-174 (km 108). B) Observar a geometria lenticular e a alternância de camadas de cascalhos sustentados por matriz, cascalhos sustentados por clastos, com intercalações de camadas de areias, resultantes de fluxos de detritos associados a fluxos torrenciais semi-confinados.

Figura 4.13: Aspectos sedimentológicos e estratigráficos do DCB. A) Seção panorâmica do afloramento P3, localizado na rodovia BR-174 (km 110,5), mostrando a geometria subhorizontal do depósito. B) O perfil estratigráfico exibe os detalhes da sucessão sedimentar, constituída por espesso pacote de cascalhos; concentrados na base.

Figura 4.14: Sucessão sedimentar característica do DCC. A) Exposição em interflúvio de baixa altitude, exemplificado pelo afloramento P10, localizado no Ramal do Brasileirinho, zona leste de Manaus. B) Perfil estratigráfico mostrando detalhes da sucessão sedimentar. As camadas possuem geometria tabular, com inclinação de $8^{\circ}$ para leste, e são caracterizadas pela associação de fácies Cmsm e Cfgi.

Figura 4.15: Exposição representativa dos depósitos DCD. A) Seção panorâmica do afloramento P11, localizado na avenida do Turismo, nas adjacências do rio Negro zona sudoeste de Manaus. Destaca-se a geometria sub-horizontal do depósito. B) No perfil estratigráfico destaca-se o caráter maciço e granulação polimoidal dos cascalhos que constituem a sucessão sedimentar do DCD.

Figura 4.16: Quadro evolutivo dos depósitos coluviais identificados, com a interpretação dos diferentes elementos e processos que atuaram na geração destes depósitos, exemplificados pelos afloramentos nos pontos P4, P3, P10, P11. A) DCA: denudação de platô com perfil laterítico, com deposição dos sedimentos por fluxos fluviais semi-confinados e de detritos (fácies $\mathrm{Am}$ e fácies $\mathrm{Cmsm}$ e $\mathrm{Cmsc}$ ). B) DCB: denudação de platô com pavimento residual detrítico constituído por argila semi-flint (fácies Cmsf). C) DCC: erosão de depósito coluvial pretérito, com deposição dos sedimentos em condições de alta energia (fácies Cmsm e Cfgi). D) DCD: denudação de perfis lateríticos imaturos e paleopavimentos residuais, com posterior deposição das partículas por fluxos torrenciais e fluxos de detritos (fácies Cmsm, Cmsc e Cgi). .59

Figura 4.17: Coluna estratigráfica proposta para a região de Manaus e Presidente Figueiredo. As sucessões sedimentares em cinza correspondem às unidades estratigráficas não aflorantes na área.

Figura 5.1: Contextualização da área de estudo na região nordeste do estado do Amazonas. A) Distribuição dos divisores topográficos, desenvolvidos sobre as rochas sedimentares da Bacia do Amazonas. A área de estudo, delimitada pela linha preta situada entre os rios Cuieiras e Preto da Eva, está desenvolvida sobre o domínio geomorfológico Planalto Dissecado Rio Trombetas - Rio Negro (Nascimento et al. 1976). B) Em destaque, os conjuntos topográficos (I, II e III), com limite das curvas de nível em 90m, individualizados pelos canais dos rios Negro, Uatumã e Jatapu. C) Distribuição das unidades geológicas da região (adaptado de Nogueira \& Sarges 2001, Rosseti et al. 2005, Nogueira et al. 2006), sobre as quais estão desenvolvidos os conjuntos topográficos, com representação do limite da área de estudo pela linha preta. D) Perfil topográfico com direção azimutal de 140, onde estão contidos os máximos e mínimos altimétricos, respectivamente pontos $\mathrm{B}$ e $\mathrm{C}$, do conjunto topográfico I.

Figura 5.2: Apresentação das características do relevo da área de estudo. A) Delimitação das faixas altimétricas representativas da distribuição e organização das formas de relevo no mapa hipsométrico B) Ângulos de declividades associados às feições geomórficas, no mapa de declividades.

Figura 5.3: Mapa de compartimentação topográfica, com delimitação de três classes de desnivelamentos. As características das classes de desnivelamento altimétricos $(\Delta \mathrm{h})$, com ilustração do perfil topográfico representativo e feições geomórficas correspondentes, são apresentadas no quadro inferior. 
Figura 5.4: A) Mapa de densidade de drenagem, mostrando as concentrações de canais de drenagem em porcentagem por $\mathrm{km}^{2}$. B) Mapa de superfície de base, com interpretação de alinhamentos associados a possíveis estruturas e comportamento das isolinhas.

Figura 5.5: A) Lineamentos interpretados a partir de imagem de relevo sombreado, com elevação de iluminação $45^{\circ}$ e azimutes NE e SE, que perfazem um total de 300 lineamentos distribuídos em uma área de $7.295 \mathrm{~km}^{2}$. Os diagramas de rosetas mostram a relação da orientação dos lineamentos conforme quantidade e o comprimento total. B) Mapa de densidade de lineamentos, mostrando as áreas com concentração dos lineamentos.

Figura 5.6: Modelo de evolução da paisagem da região de Manaus, fundamentado nas análises de superfícies de base e desnivelamento altimétrico.

Figura 6.1: Distribuição dos afloramentos estudados sobre as unidades litoestratigráficas da região de Manaus, com representação dos planos das estruturas deformacionais rúpteis medidas (falhas, juntas e fraturas), com projeção Schmidt-Lambert (hemisfério inferior). B) Contexto geológico regional da área, inserida na borda norte da Bacia do Amazonas.

Figura 6.2: Exposição da Formação Alter do Chão na zona leste de Manaus, à margem esquerda do rio Negro, que apresenta laminações convolutas, slumps, camadas interrompidas e diques clásticos (A e B), presentes em camadas intermediárias da sucessão basal desta unidade. Falhas de componentes normais sinsedimentares $(\mathrm{C}$ e D) indicam que esforços distensivos estão relacionados à geração destas estruturas deformacionais.

Figura 6.3: Seção estratigráfica da Formação Alter do Chão apresentando deformações, localizada nas adjacências da praia fluvial Ponta Negra (margem esquerda do rio Negro), zona oeste da cidade de Manaus. A) A sucessão basal apresenta laminações convolutas e falhas normais sinsedimentares, representadas no diagrama Schmidt-Lambert (hemisfério inferior), enquanto a porção superior, constituída por arenitos médios fluviais desta unidade e depósito coluvial, não apresenta deformação. Detalhes das laminações convolutas e diques clásticos na base da falha normal à esquerda (B) e das falhas de componentes normais com orientações preferenciais apresentadas nesta sucessão sedimentar (C e D).

Figura 6.4: Exposição do nível estratigráfico "Arenito Manaus", Formação Alter do Chão, na margem esquerda do rio Cuieiras. Observar a intensa deformação, representada por fraturas com relativo paralelelismo (A), onde foram medidas estrias associadas à falhas de componentes normais dextrais e normais sinistrais (B). C) As falhas medidas estão relacionadas a esforços distensivos E-W.

Figura 6.5: Seção estratigráfica da Formação Alter do Chão (A), localizada à margem esquerda do rio Negro. A porção basal, representada pelo "Arenito Manaus", mostra intenso fraturamento (A e B), onde foram medidas falhas e fraturas associadas a regime distensivo (C).

Figura 6.6: Afloramentos de arenitos médios a grossos de coloração rosa a esbranquiçado, correspondentes ao topo da Formação Alter do Chão na região de Manaus, afetados por falhas normais com rejeitos métricos. Nas adjacências do km 10 da rodovia BR-174 (A), os planos de falhas medidos apresentam componentes normais e orientações NW-SE, NE-SW, NNW-SSE e WNW-ESE (B). Ainda na BR-174, nas proximidades do $\mathrm{km} \mathrm{8}$, foram observadas falhas normais em uma voçoroca, com direção NW-SE e mergulhos para NE e SW..

Figura 6.7: Na porção leste de Manaus, no porto da Itautinga, próximo ao encontro da águas dos rios Negro e Amazonas, ocorre o afloramento com mais completo empilhamento sedimentar da Formação Alter do Chão na área de estudo e registros de diferentes fases de deformação tectônica. Falha de componente normal, com atitude N30W/45SW, que afeta também o oxissolo com linha de pedra, apresenta geometria lístrica (A), e intensa ferruginização do plano de falha com atitude N30W/45SW (B). Falhas de componentes normais com atitude N72W/55SW, que afetam somente a sucessão caulinítica inferior (C), indicam um regime de esforço distensivo anterior. As medidas de planos de falhas e juntas associadas ao falhamento curviplanar estão representadas em D..... 
Figura 6.8: Registros de atividades tectônicas posteriores aos eventos de lateritização desenvolvidos sobre a Formação Alter do Chão, na região de Manaus. A) Perfil laterítico imaturo basculado por falhas de componentes normais NW-SE. B) Representação dos planos medidos no diagrama Schmidt-Lambert (hemisfério inferior).

Figura 6.9: Registros de atividade tectônica mais nova da área de estudo, deslocando sedimentos fluviais recentes na margem direita rio Cuieiras, constituídos por areias finas a siltes de coloração avermelhada sobrepostos por camadas horizontais de arenitos médios brancoacinzentados, com grânulos de quartzo (A). Foram medidos 3 planos de falhas normais com orientações preferenciais NNW-SSE, NW-SE e WNW-ESE (B). 


\section{LISTA DE TABELAS}

Tabela 3.1: Síntese dos principais estudos geológicos sobre a Formação Alter do Chão. 15

Tabela 3.2: Terminologia aplicada a perfis lateríticos completos. Os termos descritivos estão em parênteses e os informais estão apresentados entre colchetes, conforme a proposta de Butt \& Zeegers (1992).

Tabela 4.1: Fácies, processos sedimentares e aspectos morfológicos considerados em função do controle topográfico na distribuição dos depósitos coluviais da região entre Manaus e Presidente Figueiredo. 


\section{INTRODUÇÃO}

O complexo ecossistema e biodiversidade encontrados na Amazônia foram influenciados pela dinâmica dos grandes rios. Desde o processo de reversão do rio Amazonas para leste no Neógeno, devido ao contínuo soerguimento dos Andes iniciado no Cretáceo (Hoorn et al. 1995, Mapes et al. 2006), o relevo tem sido modificado drasticamente. Barreiras geográficas relacionadas aos altos estruturais das bacias amazônicas teriam conferido rearranjos da rede de drenagem, induzidos em parte pelas movimentações neotectônicas (Roddaz et al. 2005). A alternância climática de condições mais úmidas e secas tem propiciado o desenvolvimento de perfis lateríticos que sustentam platôs desde o início do Neógeno (Horbe et al. 2001). O entendimento das conseqüências destes mecanismos na paleogeografia e principalmente na modificação da paisagem da região pode fornecer respostas para as sucessivas readaptações da fauna e flora amazônica que resultaram na biodiversidade atual. Muitos trabalhos têm considerado a influência do meio físico neste processo (Tricart 1977, Franzinelli \& Ori 1988, Molton 1991, Absy 1994, Hoorn 1994, Van der Hammen \& Absy 1994, Colinvaux \& De Oliveira 2001, Franzinelli \& Igreja 2002, Latrubesse \& Franzinelli 2002), mas poucos investigaram as características da paisagem e seus fatores controladores (e.g. Irion 1984, Behling et al. 2001, Rossetti et al. 2007).

A região de Manaus representa um dos melhores exemplos para estudo de modificações da paisagem ocorridas desde o Neógeno. Além de situar-se geograficamente entre dois grandes rios, o Negro e o Amazonas, abrange depósitos sedimentares que guardam a história geológica-geomorfológica da região, dentre os quais destacam-se os depósitos coluviais. Entretanto, ao passo que a sedimentação fluvial quaternária tem sido amplamente enfocada (v.g. Franzinelli 1987, Franzinelli \& Ori 1988, Johnson \& Meade 1990, Irion et al. 1995, Mertes et al. 1996, Latrubesse \& Franzinelli 2002, Rozo et al. 2005), ainda é escasso o conhecimento dos eventos de sedimentação coluvial e de ordenação estratigráfica dos 
depósitos cenozóicos. Além disso, a relação entre os eventos de sedimentação e as movimentações neotectônicas ainda não foi completamente estabelecida. Assim, esta pesquisa visou identificar os mecanismos que atuaram na configuração geomorfológica da região de Manaus, a partir do reconhecimento e caracterização dos depósitos sedimentares associados aos levantamentos estruturais e análises geomorfométricas.

\section{1. ÁREA DE ESTUDO}

As investigações realizadas se concentraram nos municípios de Manaus e Rio Preto da Eva, na porção entre os rios Cuieiras e Preto da Eva (Fig. 1.1), totalizando uma superfície de aproximadamente $6.550 \mathrm{~km}^{2}$. Nos estudos de sedimentação coluvial foi investigada, adicionalmente, uma faixa ao longo da BR-174, porção sul do município de Presidente Figueiredo, para obtenção de informações auxiliares para a classificação dos depósitos coluviais. A extensa cobertura florestal desta região, com exceção da área urbana do município de Manaus (Fig. 1.1), restringe as áreas de exposição de rochas e sedimentos às margens dos rios e igarapés e aos cortes de estrada, que têm seu acesso efetuado principalmente por ramais e pelas rodovias BR-174 e AM-020.

O relevo desta região é caracterizado por interflúvios tabulares com diferentes graus de dissecação, distribuídos sobre o domínio geomorfológico Planalto Dissecado Rio Trombetas - Rio Negro, cuja altimetria média é de 150m (Costa et al. 1978, Nascimento et al. 1976), com uma tendência de diminuição da altitude para sul. Uma densa rede de drenagem, com padrão geral dendrítico e fluxo em direção aos rios Negro e Amazonas caracteriza este domínio geomorfológico. 


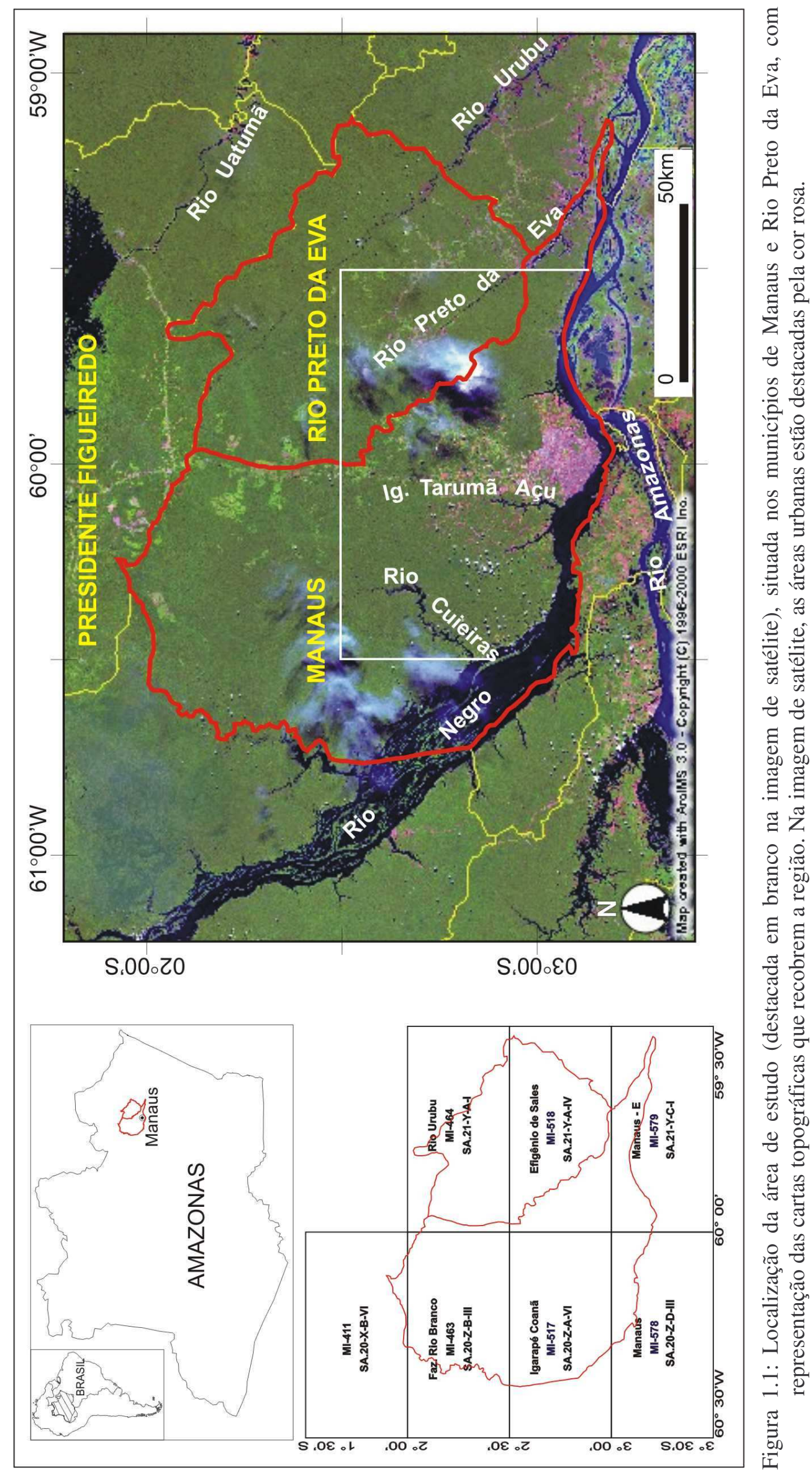




\subsection{OBJETIVOS}

O objetivo desta pesquisa foi realizar um estudo integrado de análises geomorfológica, estratigráfica e estrutural em depósitos sedimentares da área, com a finalidade de reconstituir a história evolutiva geológica-geomorfológica do Cenozóico da região de Manaus, a partir do entendimento da influência de atividades tectônicas e eventos de sedimentação cenozóica na construção do relevo da área.

\subsection{APRESENTAÇÃO DA TESE}

A tese foi organizada nos seguintes capítulos, para melhor compreensão do desenvolvimento desta pesquisa.

1 - Introdução: apresenta a temática abordada no trabalho, com uma discussão das questões e dos objetivos que nortearam o desenvolvimento da pesquisa realizada, além de apresentação da área de estudo.

2 - Materiais e métodos: descreve os procedimentos e conceitos adotados no desenvolvimento do trabalho, que fundamentaram as análises estratigráficas, estruturais e geomorfológicas empregadas.

3 - Aspectos geológicos: corresponde ao capítulo sobre as contribuições de pesquisas anteriores existentes na região, visando proporcionar um quadro sumariado destas informações, e que fundamentaram discussões sobre os aspectos estratigráficos, estruturais e geomorfológicos da área de estudo e adjacências.

4 - Depósitos sedimentares da região de Manaus: compreende a apresentação das unidades estratigráficas e depósitos sedimentares que ocorrem na área, visando à caracterização do arcabouço litoestratigráfico. 
5 - Caracterização do relevo da região de Manaus, Amazônia central: aborda as características do relevo da região por meio de parâmetros geomorfométricos dos elementos da paisagem, com definição das classes altimétricas e compartimentos topográficos da área e principais relações morfotectônicas, obtidas a partir da interpretação dos dados, buscando demonstrar o significado destes parâmetros na compreensão da história geológicogeomorfológica.

6 - A influência da tectônica mesozóica-cenozóica na paisagem de Manaus, Amazonas: este capítulo apresenta a caracterização dos regimes de esforços e definição das fases tectônicas aos quais a região esteve submetida durante o Cenozóico, com informações adicionais sobre a tectônica contemporânea à deposição da Formação Alter do Chão.

7 - Integração dos resultados: discussão do contexto evolutivo região, com integração dos dados apresentados obtidos no desenvolvimento da pesquisa.

8 - Conclusões: apresenta uma síntese dos resultados que foram alcançados neste estudo.

\section{MATERIAIS E MÉTODOS}

\subsection{ANÁLISE ESTRATIGRÁFICA}

A análise estratigráfica foi realizada por meio de levantamento de perfis e seções estratigráficas, em afloramentos na região de Manaus e adjacências de Presidente Figueiredo, onde foram descritos os litotipos, referente à litologia e estruturas, e efetuadas considerações sobre os processos sedimentares. Na caracterização estratigráfica dos depósitos sedimentares foram realizadas análises faciológica e sedimentológica, segundo a proposta de Miall (1992) e Walker (1992). As descrições das fácies coluviais foram complementadas por análises texturais por meio de separação granulométrica. Os afloramentos foram descritos e fotografados, com posterior composição de fotomosaicos para elaboração de seções 
panorâmicas (Wizevich 1991, Arnot et al. 1997). Na interpretação, destacaram-se as feições sedimentares e estruturais identificadas, com subseqüente adição dos dados obtidos em campo, que auxiliaram na definição dos elementos arquiteturais e geometria de fácies, seguindo as recomendações de Walker (1992). No posicionamento estratigráfico das unidades foi adotada a escala de tempo geológico segundo a proposta do IUGS (2007).

\subsection{ANÁLISE ESTRUTURAL}

A análise estrutural envolveu o estudo das estruturas deformacionais, principalmente as rúpteis como falhas e juntas, visando identificar os regimes de esforços resultantes de atividades neotectônicas na região de Manaus. Como atividade neotectônica foi adotada a proposta da INQUA (Mörner 1989), que limita a utilização do termo neotectônica para os movimentos tectônicos que ocorrem em até $10^{7}$ anos (Mioceno, a partir do Tortoniano).

As medições nos planos de falhas e juntas foram executadas obedecendo à notação de atitude Clar (rumo de mergulho). A partir destas medidas foram construídos estereogramas no diagrama de igual-área (Schmidt-Lambert), empregando-se o hemisfério inferior, para avaliação quantitativa e qualitativa, que subsidiaram a caracterização da deformação e determinação dos regimes de esforços que atuaram na região.

A determinação do sentido do movimento relativo dos blocos foi efetuada a partir da caracterização, em campo, dos indicadores cinemáticos nos planos de falhas, quando presentes (Petit 1987, Angelier 1994, Doblas et al. 1997), e parâmetros estratigráficos, tais como dobras de arrasto, deslocamentos de camadas e de horizontes lateríticos.

As falhas contendo estrias foram tratadas utilizando o método dos diedros retos de Angelier \& Mechler (1977), através do qual são analisados os pares falhas/estrias (Fig. 2.1), visando estabelecer os campos de tensão. A caracterização das famílias de juntas seguiu a 
proposta de Hancock \& Engelder (1989), e foram interpretadas no intuito de auxiliar a identificação dos esforços geradores destas estruturas. As estruturas deformacionais sem indicadores cinemáticos (fraturas) foram também consideradas nas análises estruturais como juntas. Na interpretação dos campos de tensões de falhas e juntas geradas por transcorrência, empregaram-se os modelos propostos para cisalhamento simples (v.g. Zalán 1986).

$\mathrm{Na}$ representação gráfica dos dados estruturais (essencialmente falhas e juntas), coletados nos sedimentos cenozóicos durante os levantamentos das seções estratigráficas, utilizou-se o programa para análises estruturais TENSOR, desenvolvido por Delvaux (2001), que emprega os conceitos em versão modificada do método dos diedros retos de Angelier \& Mecheler (1977) e possibilita o posicionamento dos eixos de tensões principais $\sigma 1$ (compressivo), $\sigma 2$ (intermediário) e $\sigma 3$ (distensivo).

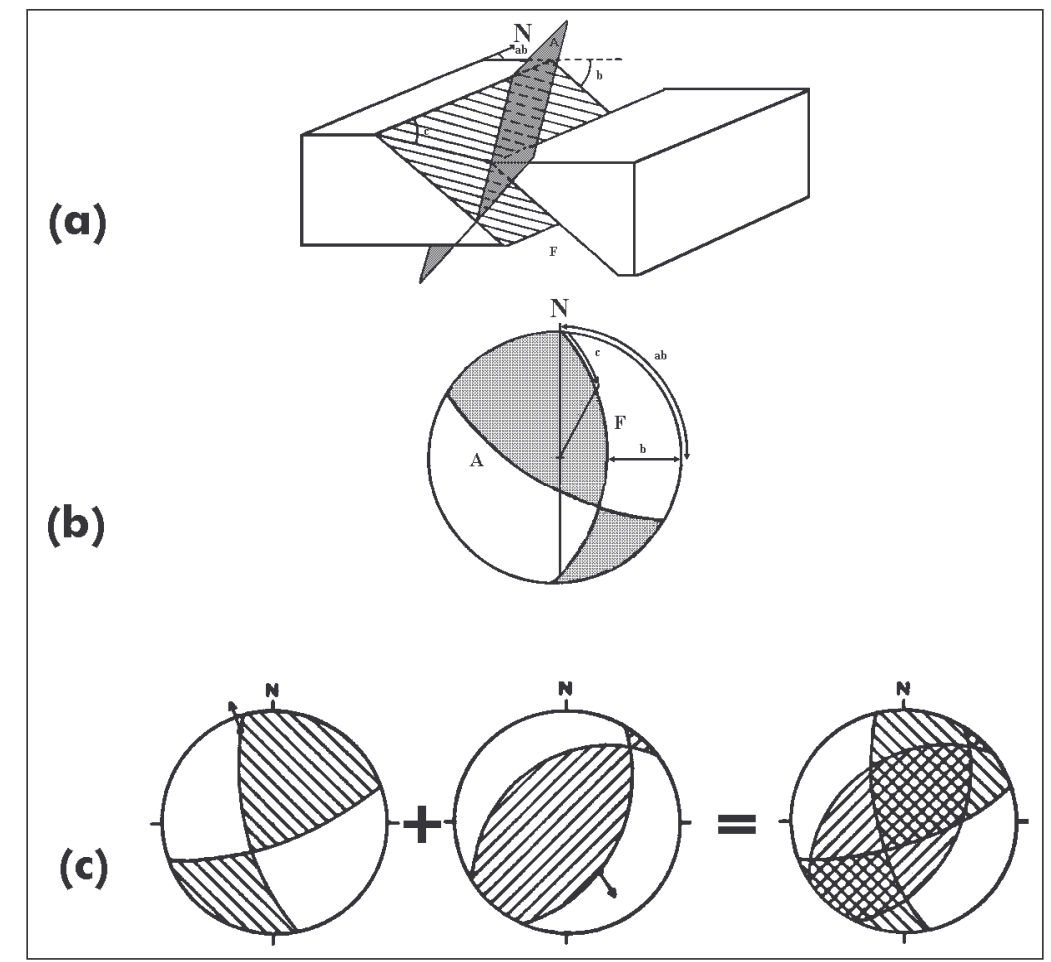

Figura 2.1: Esquema ilustrativo do método dos diedros retos proposto por Angelier \& Mechler (1977). A) Representação em bloco-diagrama das relações angulares entre o plano de falha com estrias e o plano auxiliar. B) Projeção estereográfica. C) Representação da aplicação do método, identificando os campos de compressão (hachura diagonal), extensão (em branco) e as zonas de compatibilidade (hachura quadriculada). Esta última é identificada através da superposição destes campos (fonte: Mello 1997). 


\subsection{ANÁLISE GEOMORFOLÓGICA}

A análise geomorfológica consistiu na avaliação do relevo para identificação e caracterização das feições geomórficas (e.g. canais de drenagens, formas de relevo) e processos geomorfogenéticos. Envolveu medições dos constituintes da paisagem (drenagens, declividades, quebras de relevo) visando quantificar a participação destas na composição da paisagem.

Os canais de drenagem, curvas de nível e cotas foram os principais atributos utilizados nas análises geomorfométricas e elaboração dos mapas morfométricos. Os canais de drenagens foram hierarquizados segundo a proposta de Strahler (1952), a densidade de drenagem foi analisada de acordo com a proposta de Horton (1945) e a classificação dos padrões de drenagem seguiu os conceitos de Howard (1967).

Os mapas de isobases, densidade de drenagem, declividades e densidade de lineamentos, segundo a abordagem utilizada por Hiruma (1999), constituem excelentes ferramentas auxiliares nas análises morfotectônicas (Hiruma \& Riccomini 1999, ModenesiGauttieri et al. 2002). Para a análise da distribuição das formas e definição dos compartimentos do relevo da região foram elaborados mapas de desnivelamento altimétrico e hipsométrico, segundo a abordagem empregada por Meis et al. (1982), Silva et al. (1996), Mello (1997), entre outros.

A base topográfica, utilizada na elaboração dos mapas geomorfométricos, foi gerada a partir dos seguintes produtos:

1) Cartas topográficas em escala 1:100.000 produzidas pelo IBGE (Instituto Brasileiro de Geografia e Estatística): folhas SA.20-Z-B-VI, SA.20-Z-D-III, SA.21-Y-A-IV, SA.21-YC-I (Fig. 2.2). A eqüidistância das curvas de nível é dada em 100m, o sistema de 
coordenadas é UTM (Universal Transversa de Mercator), com projeção no datum horizontal SAD-69 (South American Datum-69) e datum vertical de Imbituba (SC).

2) Modelos Digitais de Elevação (MDE's) S03W60.hgt, S03W61.hgt, S04W60.hgt e S04W61.hgt, que abrangem a área entre as coordenadas geográficas 2º30'00"S e $60^{\circ} 30^{\prime} 00^{\prime \prime} \mathrm{W}$ a $3^{\circ} 13^{\prime} 00^{\prime \prime S}$ e $59^{\circ} 30^{\prime} 00^{\prime \prime W}$ (Fig. 2.3). Estes MDE's são produtos de interferometria de radar com resolução de 3'” (aproximadamente 90m), produzidos pela missão SRTM (Shuttle Radar Topographic Mission) e disponibilizados pelo USGS (2003).

As cartas topográficas em escala de 1:100.000 foram vetorizadas e reunidas no programa AutoCAD ${ }^{\circledR}$, originando assim um único arquivo em extensão <.dxf>. As informações transformadas em dados foram canais de drenagens, pontos cotados e curvas de nível, as quais foram acrescidas os valores de elevação (Z). No programa Global Mapper ${ }^{\circledR}$, todas as cartas topográficas foram convertidas para o sistema de coordenadas geográficas (Latitude/Longitude), devido à mudança de fuso em $60^{\circ} 00^{\prime}$ S no sistema UTM, pois o fator de escala é igual a 1 no meridiano central e 1/666 (aproximadamente 0,0015015) nos extremos do fuso, sendo necessário cálculo de correção da deformação, para possibilitar a diminuição do erro de escala. A projeção adotada é o datum WGS-84 (World Global System-84), para compatibilização com a projeção adotada pela missão SRTM.

As curvas de nível das cartas topográficas do IBGE não apresentaram boa confiabilidade cartográfica, pois foram inferidas em copas de árvores e apresentaram interrupções; assim, optou-se por gerar curvas de nível a partir dos MDE's do SRTM, que possuem PEC (Padrão de Exatidão Cartográfica) de categoria A na escala 1:100.000, conforme análises cartográficas realizadas por Santos (2005), em bases de MDE's corrigidas. 
As correções foram necessárias devido a algumas características apresentadas pelos MDE's do SRTM (Valeriano 2004), tais como porções com ausência de valores altimétricos e pontos com valores altimétricos negativos.

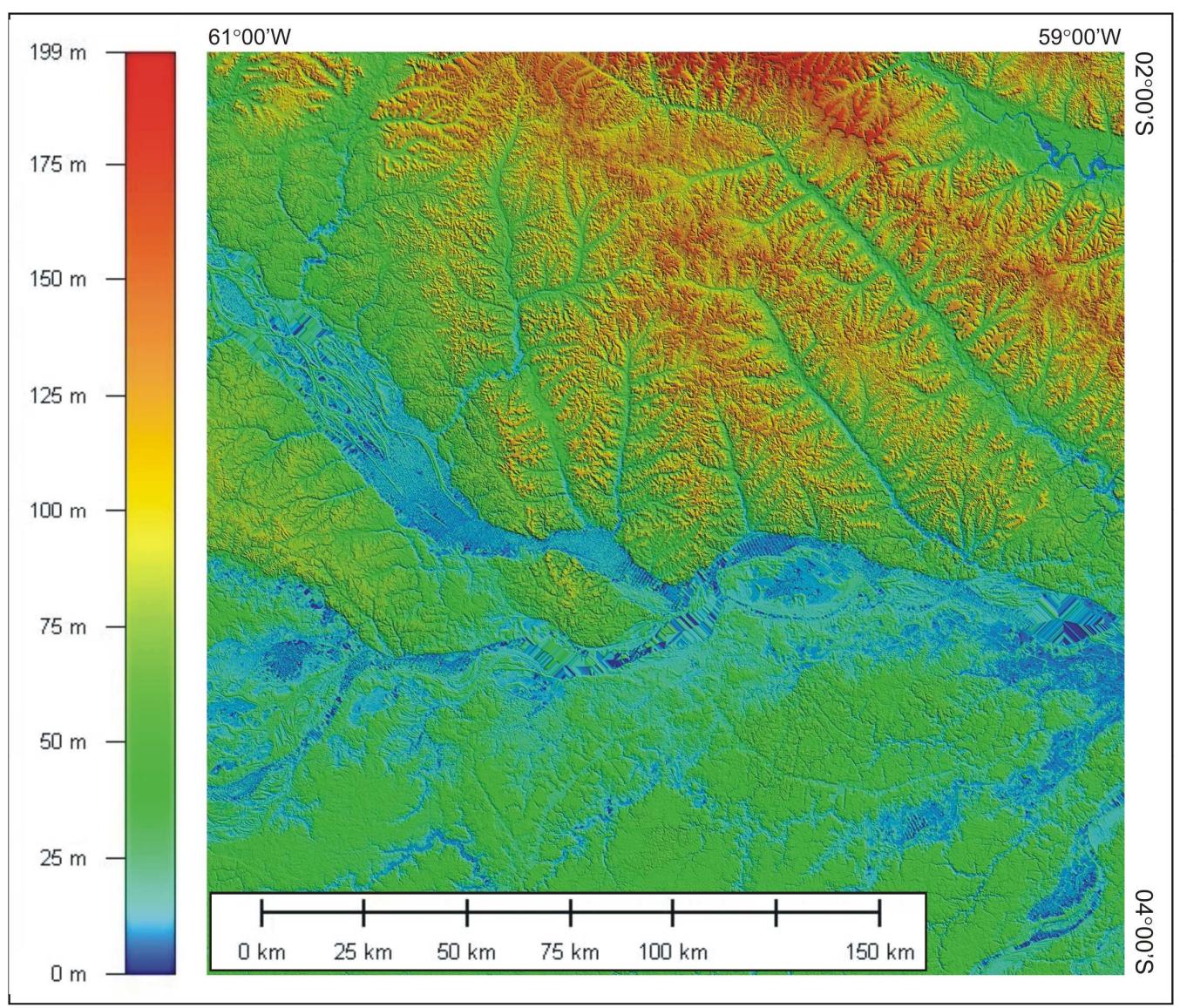

Figura 2.2: Modelo Digital de Elevação (MDE) da região de Manaus (USGS 2003), com correção de vazios altimétricos e de cotas negativas.

Conforme o procedimento adotado por Barros et al. (2004), os valores altimétricos negativos foram corrigidos com o aplicativo Blackart (Terrainmap 2005) e os vazios altimétricos foram corrigidos com aplicativo SRTMfill (3DNature 2005). Após este tratamento, os MDE's foram utilizados para geração das curvas de nível com eqüidistância de $25 \mathrm{~m}$ no programa Global Mapper ${ }^{\circledR}$. Assim, construiu-se um mapa planialtimétrico, em escala 1:100.000, composto pelas drenagens vetorizadas das cartas IBGE em escala 1:100.000 e pelas curvas de nível com eqüidistância de $25 \mathrm{~m}$, eqüidistância permitida pela 
resolução de aproximadamente 90m dos MDE's, que constituiu a base para todos os mapas geomorfométricos.

\section{ASPECTOS GEOLÓGICOS}

\subsection{LITOESTRATIGRAFIA}

As rochas mais antigas da região de Manaus são de idade cretácea (Daemon 1975, Dino et al. 1999), pertencentes à Formação Alter do Chão (Figs. 3.1 e 3.2A), que juntamente com a Formação Solimões constitui o Grupo Javari (Cunha et al. 1994). Depósitos arenosos neógenos associados a crostas ferruginosas ocorrem estritamente na porção sul de Manaus, sob a denominação informal de Formação Novo Remanso (Rozo et al. 2005), posicionada no Mioceno médio a superior (Dino et al. 2006). Depósitos arenosos, posicionados no Pleistoceno, estão descritos nas margens do rio Amazonas e nas adjacências do Arco de Purus e incluídos na Formação Içá (Maia et al. 1977), também considerada uma unidade litoestratigráfica informal.

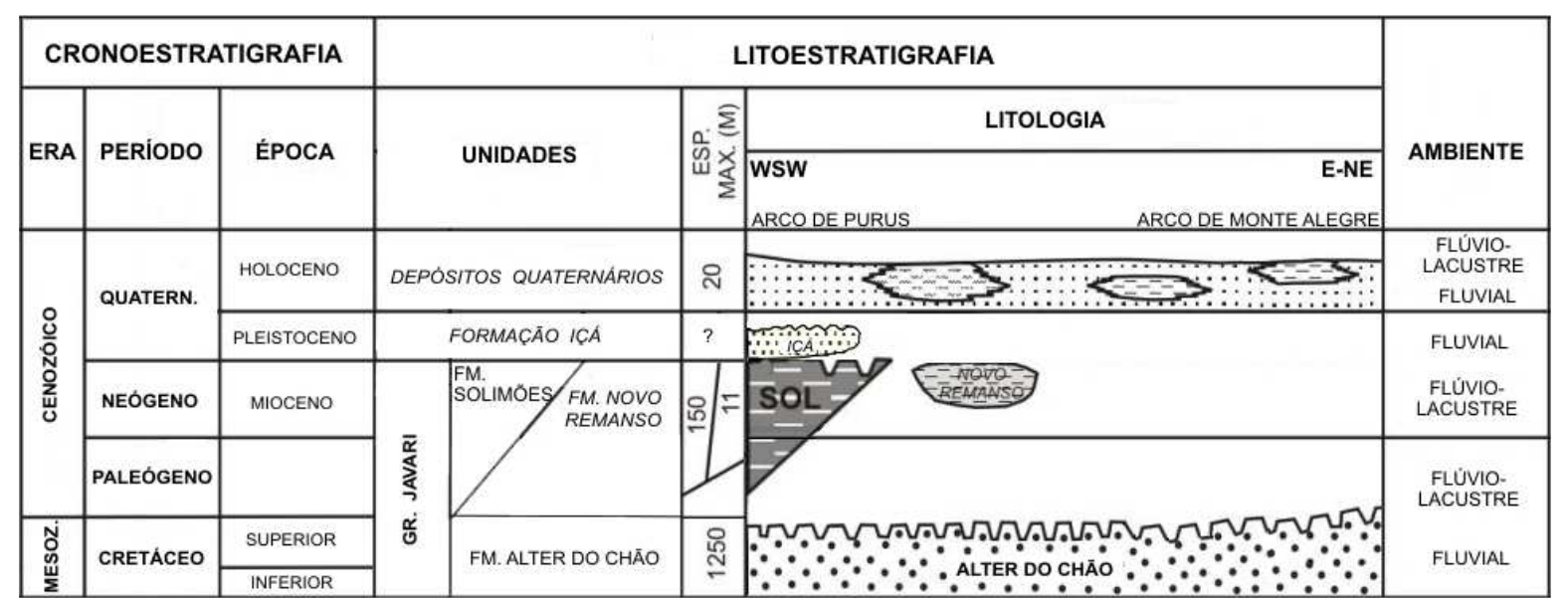

Figura 3.1: Parte superior da carta estratigráfica da Bacia do Amazonas (adaptado de Cunha et al. 1994), representada pelas formações Solimões e Alter do Chão. Foram adicionadas as unidades cenozóicas sobrepostas à bacia, constituídas pela Formação Içá (cf. Maia et al. 1977), Formação Novo Remanso e Depósitos aluviais quaternários (cf. Rozo et al. 2005). 
Associados a planícies fluviais, barra arenosas, rias fluviais e lagos das adjacências dos rios Negro e Amazonas ocorrem Depósitos aluviais, considerados de idade quaternária (Franzinelli \& Igreja 2002, Soares \& Riccomini 2003, Rosseti et al. 2005, Rozo et al. 2005). Perfis lateríticos de idade neógena incidem principalmente sobre os depósitos cretáceos.
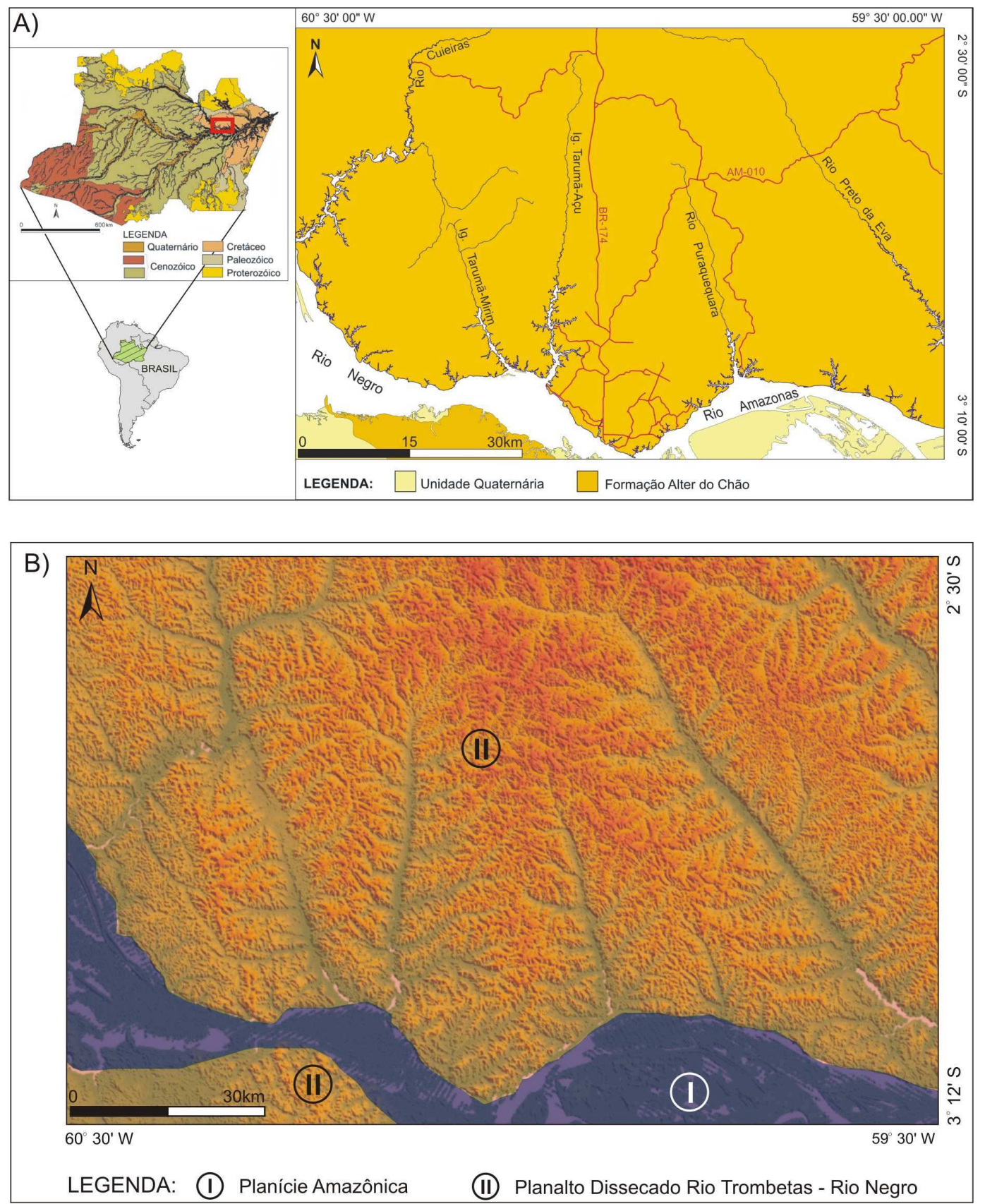

Figura 3.2: Aspectos geológicos e geomorfológicos da região de Manaus. A) Distribuição das unidades geológicas no estado do Amazonas e na área de estudo (adaptado de UFAM 2004 e Nogueira et al. 2006). B) Distribuição dos domínios geomorfológicos Planalto Dissecado Rio Trombetas-Rio Negro e Planície Amazônica sobre o MDE, segundo Nascimento et al. (1976) e Costa et al. (1978). 


\subsubsection{CRETÁCEO - A FORMAÇÃO ALTER DO CHÃO}

A área de estudo é constituída predominantemente por rochas sedimentares siliciclásticas da Formação Alter do Chão, depositadas durante o Cretáceo em ambiente fluvial a flúvio-lacustre (Cunha et al. 1994), e por subordinados depósitos neógenos e quaternários (Figs. 3.1 e 3.2A). Sobre estas unidades estão esculpidos os domínios geomorfológicos Planalto Dissecado Rio Trombetas-Rio Negro e Planície Amazônica, que mostram forte controle litológico na definição de seus limites (Fig. 3.2).

A Formação Alter do Chão representa o embasamento sobre o qual foram depositados sedimentos aluviais e coluviais durante o Cenozóico (Figs. 3.1 e 3.2A). Destacam-se a ocorrência de perfis lateríticos e solos sobre o topo desta formação, com ampla distribuição na área, que evidenciam o intenso intemperismo atuante nessa região. Esta formação é constituída por arenitos médios a grossos avermelhados, arenitos médios a grossos cauliníticos de coloração branco-acinzentada, siltitos e argilitos de coloração avermelhada e conglomerados (Caputo et al. 1972, Daemon 1975, Cunha et al. 1994). A deposição dessa unidade ocorreu sob clima predominantemente quente, com variação de seco a úmido (Daemon \& Contreiras 1971), condição climática confirmada também pela presença de esporos de fungos preservados em âmbar (Pereira et al. 2006). A idade da Formação Alter do Chão foi alternadamente admitida entre Cretáceo e Paleógeno (Tab. 3.1); mas a partir de palinomorfos, Dino et al. (1999) posicionaram esta unidade no intervalo AptianoCenomaniano (Cretáceo).

Nos primeiros mapeamentos geológicos realizados na Amazônia ocidental, as rochas sedimentares da região, atualmente comprovadas como pertencentes à Formação Alter do Chão, foram incluídas na Formação Barreiras. Contudo, estudos geológicos posteriores desfizeram este equívoco (Tab. 3.1). Somaram-se muitas evidências que impediam uma correlação daquelas rochas como pertencentes à Formação Barreiras, fato muito bem 
explorado por Santos (1975), que relacionou diversos parâmetros que mostravam a inapropriedade da inclusão destas rochas na Formação Barreiras, tais como diferenças nos aspectos tectônicos (Alter do Chão é intracratônica e Barreiras é pericratônica), cronológicos (Alter do Chão é Cretáceo e Barreiras é Neógeno), litológicas, estruturais e geográficas. Contudo, o principal critério que permitiu a inclusão destas rochas na Formação Alter do Chão foi o posicionamento estratigráfico no Cretáceo a partir dos estudos bioestratigráficos realizados por Daemon \& Contreiras (1971), Daemon (1975) e Dino et al. (1999).

Na área de Manaus, as exposições da Formação Alter do Chão consistem em depósitos de canal fluvial, compostos por conglomerados e arenitos contendo estratificações cruzada acanalada, cruzada tabular e plano-paralela, e em depósitos de planície de inundação, caracterizados por arenitos finos com laminações plano-paralela e cruzada, estratificações cruzadas tabular e acanalada, intercalados por lamitos bioturbados. Camadas silicificadas de siltitos e arenitos finos a médios vermelhos foram denominados por Albuquerque (1922) de “Arenito Manaus". Em estudo recente na região de Manaus e adjacências, Rossetti \& Netto (2006) consideraram que a presença do icnofósseis Thalassinoides associados à Planolites e Diplocraterion é uma forte evidência de influência marinha transicional na deposição da Formação Alter do Chão. Contudo, estudos sedimentológicos e faciológicos realizados na mesma área por Nogueira et al. (1999), Vieira (1999), Franzinelli \& Igreja (2002) e Rozo et al. (2005), identificaram estruturas típicas de ambiente fluvial a flúvio-lacustre, que confirmam deposição desta unidade em ambiente fluvial, em sistema de rios entrelaçados e meandrantes. Nos arenitos finos desta unidade foram descritos paleossolos apresentando mosqueamento, gretas de contração profundas e abundantes traços de raízes e de habitação de Scoyenia (Nogueira et al. 1999). 


\begin{tabular}{|c|c|c|c|}
\hline Autor & Área Estudada & Contribuição & Cronologia \\
\hline Kistler (1954) & $\begin{array}{l}\text { Rio } \quad \text { Tapajós }(\mathrm{PA}) \\
\text { Poço } \\
\text { (seção-tipo). }\end{array}$ & $\begin{array}{l}\text { Propôs a utilização da denominação de "Alter do } \\
\text { Chão" para as rochas admitidas na região como } \\
\text { pertencentes à Formação Barreiras. }\end{array}$ & $\begin{array}{l}\text { Posicionamento relativo } \\
\text { no Cretáceo. }\end{array}$ \\
\hline Price (1960) & $\begin{array}{l}\text { Nova Olinda (AM), } \\
\text { Poço NO-1-AM. }\end{array}$ & $\begin{array}{l}\text { Identificou um dente de dinossauro da classe } \\
\text { Theropoda, sendo a primeira referência fossilífera da } \\
\text { idade cretácea. }\end{array}$ & Neocretáceo \\
\hline $\begin{array}{l}\text { Caputo et al. } \\
\quad \text { (1971) }\end{array}$ & $\begin{array}{l}\text { Bacia do Amazonas } \\
\text { (baixo, médio e parte } \\
\text { do alto Amazonas). }\end{array}$ & $\begin{array}{l}\text { Sugeriram que a parte inferior da Formação Alter do } \\
\text { Chão é cretácea enquanto a superior é terciária até o } \\
\text { contato discordante erosivo com Formação Solimões } \\
\text { (Paleógeno a Pleistoceno). }\end{array}$ & Cretáceo-Terciário \\
\hline $\begin{array}{l}\text { Daemon \& } \\
\text { Contreiras } \\
\quad(1971)\end{array}$ & $\begin{array}{ll}\text { Poços 1-MD-1AM } \\
\text { (Madeirinha } & \text { AM) e } \\
\text { 1MA-1-PA } & \text { (Monte } \\
\text { Alegre - PA). }\end{array}$ & $\begin{array}{l}\text { Estabeleceram que a Formação Alter do Chão } \\
\text { corresponde ao intervalo bioestratigráfico XVII, } \\
\text { caracterizado por palinomorfos semelhantes aos do } \\
\text { Cretáceo Superior da Bacia Barreirinhas }\end{array}$ & $\begin{array}{l}\text { Cenomaniano a } \\
\text { Maastrichtiano }\end{array}$ \\
\hline $\begin{array}{l}\text { Caputo et al. } \\
\quad(1972)\end{array}$ & $\begin{array}{l}\text { Quase toda a extensão } \\
\text { da Bacia do Amazonas. }\end{array}$ & $\begin{array}{l}\text { Reforçaram a impropriedade do termo "Série } \\
\text { Barreiras" e incluíram o "Arenito Manaus", de } \\
\text { Albuquerque (1922), como um dos litotipos da } \\
\text { Formação Alter do Chão. Documentaram que a } \\
\text { espessura alcança 545m na seção-tipo. }\end{array}$ & $\begin{array}{c}\text { Eocenomaniana até } \\
\text { possivelmente Plioceno }\end{array}$ \\
\hline $\begin{array}{l}\text { Santos et al. } \\
\quad(1974)\end{array}$ & $\begin{array}{l}\text { Amazônia Central e } \\
\text { Ocidental. }\end{array}$ & $\begin{array}{l}\text { Descartou a idéia de contato gradacional entre as } \\
\text { formações Alter do Chão e Solimões proposta por } \\
\text { Caputo et al. (1971), pois mapearam contato } \\
\text { discordante entre estas unidades. }\end{array}$ & $\begin{array}{l}\text { Admitiu a proposta de } \\
\text { Daemon \& Contreiras } \\
\text { (1971): Cenomaniano a } \\
\text { Maastrichtiano. }\end{array}$ \\
\hline Souza (1974) & $\begin{array}{l}\text { Rodovia } \quad \text { BR-174 } \\
(\mathrm{AM})\end{array}$ & $\begin{array}{l}\text { Mapeou sucessões sedimentares aflorantes como } \\
\text { pertencentes à Formação Alter do Chão. }\end{array}$ & Cretáceo superior \\
\hline $\begin{array}{l}\text { Daemon } \\
(1975)\end{array}$ & $\begin{array}{l}\text { Poços AC-1-PA (Alter } \\
\text { do Chão-PA) e NO-1- } \\
\text { AM (Nova Olinda- } \\
\text { AM). }\end{array}$ & $\begin{array}{l}\text { A partir de estudos em palinomorfos, considerou ser } \\
\text { improvável a deposição ininterrupta desta formação. }\end{array}$ & $\begin{array}{l}\text { Albiano Médio a } \\
\text { Superior e Cenomaniano } \\
\text { a Turoniano. }\end{array}$ \\
\hline $\begin{array}{l}\text { Travassos \& } \\
\text { Barbosa Filho } \\
\quad(1990)\end{array}$ & $\begin{array}{lr}\text { Poços } & 1-A C-1-P A \\
\text { (Alter do Chão-PA), 1- } \\
\text { GU-1-PA (Gurupá-PA) } \\
\text { e r } 1 \text {-AL-1-PA } \\
\text { (Almerim-PA). }\end{array}$ & $\begin{array}{l}\text { A partir estudos em palinomorfos, admitiram que os } \\
\text { sedimentos do poço 1-AC-1-PA são pertencentes ao } \\
\text { intervalo Albiano-Mioceno, enquanto aqueles } \\
\text { encontrados nos poços 1-GU-1-PA e 1-AL-1-PA } \\
\text { foram atribuídos ao Terciário (Eoceno?). }\end{array}$ & $\begin{array}{l}\text { Albiano a Mioceno } \\
\text { (Poço 1-AC-1-PA); } \\
\text { Terciário (Eoceno?) } \\
\text { (poços 1-GU-1-PA e 1- } \\
\text { AL-1-PA) }\end{array}$ \\
\hline $\begin{array}{l}\text { Cunha et al. } \\
\text { (1994) }\end{array}$ & $\begin{array}{l}\text { Toda a Bacia do } \\
\text { Amazonas. }\end{array}$ & $\begin{array}{l}\text { Sintetizou os dados paleoambientais e a evolução } \\
\text { tectônica, apresentando a carta estratigráfica da } \\
\text { Bacia do Amazonas. }\end{array}$ & Cretáceo-Terciário \\
\hline Vieira (1999) & Manaus (AM). & Caracterização faciológica em afloramentos. & Cretáceo-Terciário \\
\hline $\begin{array}{l}\text { Dino et al. } \\
\quad(1999)\end{array}$ & $\begin{array}{l}\text { Parte ocidental da } \\
\text { Bacia do Amazonas. }\end{array}$ & Datação relativa a partir de palinomorfos. & Aptiano-Cenomaniano \\
\hline $\begin{array}{l}\text { Nogueira et al. } \\
\text { (1999) }\end{array}$ & Manaus (AM). & $\begin{array}{l}\text { Identificaram e descreveram paleossolos em } \\
\text { afloramentos. }\end{array}$ & Cretáceo-Terciário \\
\hline
\end{tabular}

Tabela 3.1: Síntese dos principais estudos geológicos sobre a Formação Alter do Chão. 


\subsubsection{NEÓGENO}

\subsubsection{Formação Novo Remanso}

A Formação Novo Remanso (Fig. 3.1), definida por Rozo et al. (2005), aflora nas proximidades das margens do rio Solimões e está desenvolvida sobre a Formação Alter do Chão. Esta unidade é composta por arenitos ferruginosos grossos e arenitos finos a médios, friáveis, moderadamente selecionados, que constituem ciclos granodecrescentes ascendentes sobrepostos por argilas maciças, laminadas e mosqueadas, depositados em ambiente fluvial meandrante (Rozo et al. 2005, Nogueira et al. 2006). Esta unidade é limitada na base por crosta laterítica colunar, porosa e vermiforme, e no topo por crosta laterítica maciça, cavernosa, localmente pisolítica (Horbe et al. 2004).

\subsubsection{Depósitos Aluviais e Coluviais}

Sobrepostos à Formação Alter do Chão ocorrem depósitos aluviais, distribuídos principalmente às margens dos rios Negro e Amazonas (Figs. 3.1 e 3.2), e depósitos coluviais areno-argilosos e argilo-arenosos, cuja ordenação estratigráfica ainda não está definida. Em estudo realizado na região do Médio Amazonas, Meis (1971) considerou que a geração dos depósitos coluviais desta região está associada à atuação de processos denudacionais. Neste trabalho preliminar, fundamentado em estudos de formas topográficas e registros estratigráficos, esta autora sugere que as sucessivas fases de denudação, que originaram os depósitos coluviais, estiveram condicionadas a fatores climáticos (Fig. 3.3).

Os sedimentos arenosos a argilosos amarelados, pedogeneticamente classificados de oxissolos (latossolos) e geralmente sobrepostos aos níveis ferruginosos dos perfis lateríticos e às linhas de pedras, têm expressiva distribuição geográfica na área de estudo. A origem destes sedimentos ainda é discutida, mas as principais idéias são: 1) resultante da erosão e transporte 
de solos de perfis lateríticos (Truckenbrodt \& Kotschoubey 1981); 2) derivados da alteração in situ de sedimentos da Formação Alter do Chão (Chauvel et al. 1982); 3) gerados pelos processos de saprolitização e argilização durante a lateritização, a partir de evidências geoquímicas de autoctonia (Horbe \& Costa 1999, 2004).

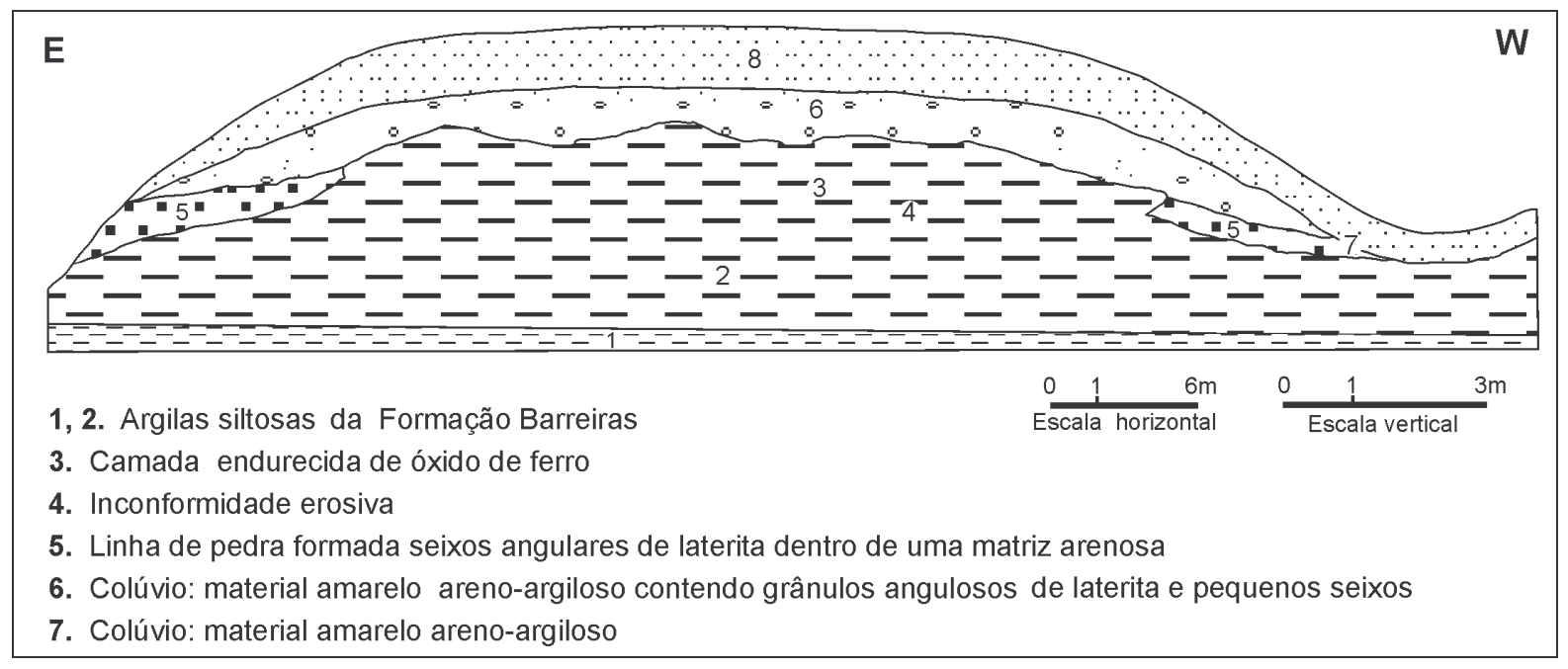

Figura 3.3: Exposição representativa dos depósitos sedimentares relacionados à sedimentação coluvial da região de Manaus, segundo Meis (1971). Ressalta-se que a unidade considerada como "Barreiras" corresponde à Formação Alter do Chão. O pacote 8 corresponde aos oxissolos amarelos.

Na porção nordeste do Amazonas, os oxissolos e sedimentos argilosos associados foram denominados de Coberturas Neocenozóicas por Horbe et al. (1997) e Nogueira et al. (1997). Estes autores os correlacionaram à "Argila de Belterra" de Sombroek (1966), porém sem concordar com a origem lacustre sugerida, e admitiram a idade Paleógeno a PlioPleistoceno proposta por Costa (1991).

Os sedimentos aluviais compreendem areias, siltes e argilas depositadas nas proximidades dos rios Negro e Amazonas. Morfologicamente, estes depósitos correspondem aos vales, terraços fluviais e planícies de inundação. 


\subsection{PERFIS LATERÍTICOS}

Os processos intempéricos químicos, que levam à alteração das rochas, são extremamente vigorosos em regiões tropicais, especialmente nas úmidas. Como resultado, formam-se os perfis lateríticos, cuja gênese, composição química e evolução estão condicionados às propriedades litológicas e a fatores tectônicos, climáticos e geomorfológicos (McFarlane 1976, Schellmann 1979, Nahon \& Tardy 1992). Perfis lateríticos consistem em níveis de alteração desenvolvidos in situ sobre rochas que sofreram intenso intemperismo (Tab. 3.2), estruturados em horizontes com características distintas entre si (McFarlane 1976, Schellmann 1979, Lucas et al. 1989, Nahon \& Tardy 1992, Tardy 1993). Estes perfis podem ter suas evoluções completas, sugestivas de condição ambiental estável, ou interrompidas, devido a mudanças nas condições ambientais (climáticas ou tectônicas).

Um evento de lateritização de abrangência mundial ocorreu durante o Eoceno, com desenvolvimento de crostas ferruginosas que são utilizadas como marcadores estratigráficos (Valeton 1999). As alternâncias climáticas, desde condições de clima seco nos intervalos Cretáceo Superior-Paleoceno e no Oligoceno ao de clima úmido no Eoceno e Mioceno (Tardy \& Roquin 1998), favoreceram o desenvolvimento dos perfis lateríticos em várias partes do mundo.

Na Amazônia, foram descritas fases de lateritização que ocorreram desde o EocenoOligoceno até o Mioceno e foram responsáveis pelo desenvolvimento dos perfis lateríticos mais antigos, enquanto os mais recentes ou os que tiveram sua evolução interrompida formaram-se no Plio-Pleistoceno (Costa 1990, 1991, Horbe et al. 1997, 2001). A distribuição geográfica de perfis lateríticos, segundo Costa (1991), compreende as regiões de Gurupi (PAMA), Paragominas (PA), Carajás (PA), Baixo Amazonas, Pitinga (AM), Manaus (AM), Cassiporé (AP), Vila Nova (AP), Serra do Navio (AP), Tucuruí (PA), Quatipuru (PA). 


\begin{tabular}{|c|c|c|c|c|c|}
\hline \multirow{2}{*}{$\begin{array}{c}\text { MAIORES } \\
\text { SUBDIVISÕES }\end{array}$} & \multirow[b]{2}{*}{ TERMOS GERAIS } & \multicolumn{4}{|c|}{ TERMINOLOGIA ALTERNATIVA } \\
\hline & & $\begin{array}{c}\text { BUTT \& ZEEGERS } \\
\text { (1992) }\end{array}$ & $\begin{array}{c}\text { NAHON \& } \\
\text { TARDY (1992) }\end{array}$ & FRANCESA & CSIRO \\
\hline \multirow{7}{*}{ Pedolito } & $\begin{array}{l}\text { Solo ferruginoso } \\
\text { [Latossolo] }\end{array}$ & Solo & Solo & Solo ferralítico & Solo \\
\hline & $\begin{array}{l}\text { Zona ferruginosa } \\
\text { [Laterito] }\end{array}$ & Cascalho laterítico & $\begin{array}{l}\text { Camada de seixos } \\
\text { ferruginosos }\end{array}$ & - & Cascalhos lateríticos \\
\hline & \multirow[t]{2}{*}{ [Ironstone laterítico] } & $\begin{array}{c}\text { Couraça (pisolítica, } \\
\text { nodular, maciça) }\end{array}$ & $\begin{array}{c}\text { Crosta ferruginosa } \\
\text { conglomerática } \\
\text { endurecida }\end{array}$ & Couraça [ferricrete] & \multirow{2}{*}{$\begin{array}{l}\text { Duricrosta laterítica } \\
\text { (pisolítica, nodular, } \\
\text { maciça, vermiforme, } \\
\text { fragmentada) }\end{array}$} \\
\hline & & & $\begin{array}{l}\text { Crosta nodular } \\
\text { macia }\end{array}$ & Carapaça nodular & \\
\hline & \multirow{3}{*}{ Zona Mosqueada } & $\begin{array}{l}\text { Zona (argilosa) } \\
\text { Mosqueada }\end{array}$ & \multirow{3}{*}{$\begin{array}{l}\text { Zona (argilosa) } \\
\text { Mosqueada }\end{array}$} & \multirow{3}{*}{$\begin{array}{l}\text { argiles tachetées - } \\
\text { argilas mosqueadas }\end{array}$} & Zona Mosqueada \\
\hline & & \multirow{2}{*}{$\begin{array}{c}\text { Horizonte } \\
\text { Plásmico/arenoso }\end{array}$} & & & $\begin{array}{c}\text { Horizonte } \\
\text { Plásmico/arenoso }\end{array}$ \\
\hline & & & & & $\begin{array}{l}\text { Saprolito colapsado } \\
\text { e/ou brechado }\end{array}$ \\
\hline \multirow[t]{2}{*}{ Saprolito } & \multirow{2}{*}{$\begin{array}{c}\text { Saprolito } \\
\text { [zona pálida] }\end{array}$} & Saprolito & Saprolito fino & $\begin{array}{l}\text { Lithomarge - } \\
\text { argiles bariolées }\end{array}$ & $\begin{array}{c}\text { Saprolito ferruginoso } \\
\text { Saprolito argilosos } \\
\text { Saprolito }\end{array}$ \\
\hline & & Saprock & Saprolito grosso & $\begin{array}{l}\text { Alteração Pistache } \\
\text { Arenoso/grosso }\end{array}$ & Saprock \\
\hline Protolito & Rocha sã & Rocha sã & Rocha sã & Rocha sã & Rocha sã \\
\hline
\end{tabular}

Tabela 3.2: Terminologia aplicada à perfis lateríticos completos. Os termos descritivos estão em parênteses e os informais estão apresentados entre colchetes, conforme a proposta de Butt \& Zeegers (1992).

Na região de Manaus, estão registrados dois tipos de perfis lateríticos (Fernandes Filho 1996), ambos desenvolvidos sobre a Formação Alter do Chão: 1) perfis com desenvolvimento completo, que se mostram estruturados, da base para o topo, em horizontes transicional, argiloso, esferulítico e solo e apresentam crosta ferruginosa; 2) perfis com evolução truncada, que possuem somente horizontes argilosos ou transicionais e estão associados às linhas de pedras constituídas por nódulos ferruginosos. Estes dois tipos de perfis mostram-se freqüentemente afetados por falhas, evidenciadas pelo deslocamento dos horizontes ferruginosos (Fernandes Filho et al. 1995, 1997). 
Oxissolos, análogos aos latossolos da classificação adotada pela Embrapa (1999), desenvolveram-se sobre os perfis lateríticos, depósitos coluviais e Formação Alter do Chão, indistintamente. Segundo a classificação de solos do Soil Survey Staff (1975), que fundamentou a reformulação da classificação de solos da Embrapa (1999), os oxissolos são solos de regiões tropicais úmidas, caracterizados por altas taxas de lateritização. Na região do Amazonas, estes solos foram estudados e caracterizados por Nascimento et al. (1976), Costa et al. (1978), Nortcliff (1989) e Horbe et al. (2003).

No topo dos perfis lateriticos é comum a concentração de fragmentos grossos residuais, dispostos paralelamente à superfície, em geral de tamanho seixo ou bloco, denominada na literatura de linha de pedra (Ruhe 1959). As linhas de pedras podem ter origem alóctone ou autóctone. $\mathrm{Na}$ origem alóctone, a linha de pedra constitui um pavimento residual erosivo soterrado, originalmente submetido à ação de escoamento superficial, com subseqüente recobrimento por sedimentos superficiais (Ruhe 1959, Bigarella \& Mousinho 1965). As linhas de pedras autóctones podem ser geradas de duas maneiras distintas: 1) a partir da bioturbação, com segregação dos sedimentos finos por atividade animal, resultando em concentração de frações grossas residuais (Nye 1954, Johnson 1990); e 2) a partir de intenso intemperismo químico (Aleva 1989), que favorece a concentração de ferro em nódulos irregulares.

Diversos trabalhos na Amazônia documentam linhas de pedras com espessuras centimétricas constituídas por nódulos ferruginosos, com tamanho médio de $2 \mathrm{~cm}$ de diâmetro (e.g. Costa 1991, Fernandes Filho 1996, Horbe et al. 2001), cuja origem é atribuída a processos de lateritização atual na região (Franzinelli \& Piuci 1988), compatível com a origem intempérica proposta por Aleva (1989). Há, ainda, registros de linhas de pedras de origem alóctone, que caracterizam paleopavimentos erosivos (Fernandes et al. 1997, Horbe et al. 2003). 


\subsection{TECTÔNICA CENOZÓICA}

O marcante alinhamento das drenagens da região amazônica em duas direções preferenciais, NE-SW e NW-SE, e a presença de feições retilíneas e ortogonais em trechos de rios foram descritos por Sternberg (1950), que publicou o trabalho pioneiro sobre neotectônica no Brasil, sugerindo a existência de um sistema conjugado de juntas ou falhas, cuja origem poderia ter sido causada por sismos. Em trabalho posterior, Sternberg (1955) relaciona lineamentos e alinhamentos no relevo aos diversos registros de sismos que ocorreram na Amazônia, dentre eles o de 1690, documentado pela estação do Observatório Nacional.

A evolução dos estudos na região, com a utilização dos conceitos da tectônica de placas, confirmaram que os lineamentos interpretados por Sternberg (1950) estão associados à atuação de movimentações neotectônicas em diversas partes da região (Franzinelli \& Igreja 1990, Bemerguy \& Costa 1991, Costa et al. 1993, 1996, 2001, Franzinelli \& Igreja 2002, Latrubesse \& Franzinelli 2002). Entre os rios Purus e Negro, Franzinelli \& Latrubesse (1993) observaram que, embora os principais lineamentos sejam NE-SW e NW-SE, também existem alinhamentos com direções preferenciais E-W e N-S, que coincidem com desembocaduras afogadas ("rias fluviais") e trechos anômalos nos canais dos rios Negro e Solimões.

Os esforços atuantes na Placa Sul-Americana desde a reativação Wealdeniana (Almeida 1967, 1969), também denominado de Evento Sul-Atlantiano (Schobbenhaus \& Campos 1984), são considerados como resultantes da interação entre as forças de flutuação (topográficas), representadas pelo empurrão exercido pela cadeia Meso-Atlântica, e os esforços compressivos impostos a partir do limite oeste da placa, na fossa Peru-Chile, onde as tensões associadas a estes esforços consistem em distensão na área emersa e compressão na submersa (Assumpção 1992, Coblentz \& Richardson 1996, Ferrari 2001). 
A tensão intraplaca apresenta uma quase uniforme orientação E-W do SHmax para a maioria das regiões da placa Sul-Americana (Zoback et al. 1989, Assumpção 1992, Richardson \& Coblentz 1994, Coblentz \& Richardson 1996, Riccomini \& Assumpção 1999, Ferrari 2001), concordante com a direção de movimentação da placa e com o empurrão exercido pela Cadeia Meso-Atlântica, que impõe um campo de esforços compressivos E-W, enquanto que a tensão horizontal mínima $\left(\mathrm{Sh}_{\min }\right)$, de caráter distensivo, imprime esforços direcionais (Zoback et al. 1989, Assumpção 1992, Ferrari 2001).

No noroeste da Placa Sul-Americana, Colmenares \& Zoback (2003) investigaram a interação complexa entre as placas Sul-americana, Caribe e Nazca, onde definiram três regiões com domínios distintos de tensão. Nos Andes Equatorianos exibe compressão E-W, resultante do subducção da Placa de Nazca sob a Placa Sul-Americana; no noroeste da Placa Sul-Americana ocorre compressão NW-SE, associada à força ascensional negativa da Placa do Caribe subductada sob a Placa Sul-Americana ou da colisão contínua da microplaca Costa Rica-Panamá; e na Venezuela Setentrional foi identificada uma distensão NE-SW.

Os reflexos de esforços tectônicos durante o Cenozóico na região amazônica estão registrados em deformações nos estratos sedimentares da Bacia do Amazonas, que foram interpretadas por Costa (2002) como resultantes da interação complexa dos esforços entre as placas do Caribe e Sul-Americana e associadas a tensões intraplaca compressivas e distensivas, correlacionadas ao binário dextral resultante da roto-translação da placa SulAmericana para NW. Embora as interpretações sísmicas em sua pesquisa não sejam suficientes para identificar as estruturas relacionadas aos eventos quaternários, Costa (2002) sugere que a Bacia do Amazonas tem permanecido tectonicamente ativa durante o Quaternário, em porções diferenciadas.

Riccomini \& Assumpção (1999) consideram que os indicadores de tectônica quaternária na Bacia do Amazonas correspondem a lineamentos estruturais, associados a 
segmentos ao longo do vale do rio Amazonas, e falhas lístricas NE, normais planares e transcorrentes dextrais. Dentre diversos estudos que buscaram esclarecer a atuação de atividades tectônicas cenozóicas nesta parte da Amazônia, podemos destacar:

1) O modelo tectônico proposto por Franzinelli \& Igreja (1990), baseado em análises fotointerpretativas, que assume um regime transcorrente dextral com direção E-W, que teria gerado falhas normais com direção NW e mergulho para NE, relacionado à rotação da Placa Sul-Americana, com eixo de distensão máxima N50-55E e eixo de compressão S30E máxima.

2) A proposta de evolução tectônica apresentada por Wanderley Filho (1991), que considera que o final da evolução da Bacia do Amazonas esteve sob regime tectônico distensivo no Paleógeno, que produziu falhas normais NE-SW e falhas normais lístricas NW-SE. Durante o Mioceno, um regime transcorrente dextral foi responsável pela geração de esforços compressivos na região do Baixo Amazonas.

3) O estudos desenvolvido na região de Manaus por Fernandes Filho (1996), que propôs um quadro tectônico para a região de Manaus, onde esforços compressivos, que atuaram provavelmente no Mioceno, geraram falhas inversas NE-SW na Formação Alter do Chão e soerguimentos dos perfis lateríticos, submetendo-os a intensa erosão. No Pleistoceno médio a superior, uma transcorrência dextral gerou esforços transtensivos, responsáveis pelo abatimento da região sudoeste e soerguimento da região nordeste e deram origem aos prismas com estruturas do tipo graben e horst, aos quais estão associados falhas transcorrentes NE-SW e EW e falhas normais NW-SE. Um terceiro pulso de transcorrência, admitido como Pleistoceno superior-Holoceno, gerou falhas NE-SW, que bascularam as linhas de pedras. 
4) O modelo de Costa et al. (2001), que consideram dois eventos neotectônicos na região de Manaus, resultantes de esforços intraplaca que vigoram na região desde o Paleógeno até o Holoceno. O primeiro, que teria atuado no Mioceno-Plioceno, foi responsável pela formação de falhas reversas e dobras NE-SW nos sedimentos da Formação Alter do Chão e controlam os alinhamentos de feições geomórficas com altitudes de até 200 m, admitidas como remanescentes de uma transpressão. Durante o Plioceno-Holoceno, falhas normais NW-SE associadas a falhas transcorrentes dextrais EW (na porção de Manaus) e NE-SW (ao longo do rio Madeira), teriam originado bacias de afastamento que acolheram os sedimentos fluviais quaternários. Estas estruturas estão associadas a esforços distensivos, que controlam as direções das desembocaduras dos rios Uatumã, Urubu, Preto da Eva e Negro, com possível relação com a inversão do fluxo do paleo-rio Amazonas de oeste para leste. Porém, estes autores admitem que os dados disponíveis ainda são insuficientes para uma interpretação cinemática conclusiva.

5) A investigação realizada por Costa (2002), que apoiado em dados sismoestratigráficos, investigou os efeitos de halotectônica e movimentos tectônicos cenozóicos na Bacia do Amazonas e caracterizou dois eventos tectônicos para a região. O evento préMioceno, de abrangência local, afetou apenas a Formação Alter do Chão, na região da Plataforma de Manaus, e originou dobras e falhas transcorrentes orientadas para NESW, relacionadas a esforços transpressivos. O evento tectônico admitido como MioPlioceno, de maior intensidade e abrangência, gerou dobras e falhas transcorrentes relacionadas esforços transpressivos e foi responsável pela movimentação salífera (halotectonismo).

6) A proposta de evolução tectônica apresentada por Silva (2005), que foi fundamentada em medidas de falhas e análises de paleotensões, admite um sistema distensivo 
cretáceo que vigorou durante a deposição da Formação Alter do Chão e produziu falhas normais NE-SW e NNW-SSE. Em seguida, foi implantado um regime compressivo NE-SW, ao qual foi atribuída a modificação da rede de drenagem para o atual sistema do rio Amazonas e a sedimentação da Formação Solimões, que gerou falhas inversas NE-SW; porém, este autor atribuiu as paleotensões com $\sigma 1$ NW-SE, $\sigma 2$ NE-SW e $\sigma 3$ subvertical, incompatíveis com as orientações das estruturas por ele apresentada. Seguiu-se um soerguimento flexural associado a uma compressão exercida pela Placa do Caribe. No final do Cenozóico, formaram-se falhas transcorrentes dextrais e sinistrais associadas ao regime tectônico transcorrente dextral E-W, que deformou a Formação Alter do Chão e as crostas ferruginosas dos perfis lateríticos, favoreceu a instalação de bacias quaternárias e condicionou as planícies fluviais da região.

7) Mais recentemente, a proposta de evolução tectono-sedimentar para a região entre Manacapuru e Manaus, apresentada por Soares (2007), que admite a vigência de esforços distensivos, possivelmente radiais, que deformaram a Formação Alter do Chão. No Pleistoceno, esforços distensivos NW-SE afetaram a Formação Novo Remanso e reativaram falhas normais NE-SW. Uma sucessão de pulsos tectônicos foram documentados em depósitos sedimentares com idades entre 66.000 e 6.000 anos AP. (Pleistoceno Superior a Holoceno), representados por esforços distensivos N-S, sucedidos por esforços distensivos NE-SW e, por último, uma distensão E-W. Estes últimos eventos distensivos foram correlacionados a uma possível interação de forças produzidas pelos deslocamentos da Placa Sul-Americana para oeste e da Placa do Caribe para leste. 


\subsection{GEOMORFOLOGIA}

Os mapeamentos geomorfológicos no nordeste do Amazonas realizados durante o Projeto Radambrasil na década de 70 (Nascimento et al. 1976, Costa et al. 1978), resultaram na definição dos domínios morfoestruturais da região abrangida pelas folhas Manaus (AM) e Santarém (PA), denominados Planalto Dissecado Norte da Amazônia, Pediplano Rio BrancoRio Negro, Depressão Periférica Norte do Pará, Planalto Rebaixado da Amazônia Ocidental, Planalto da Bacia Sedimentar do Amazonas e Planalto Dissecado Rio Trombetas-Rio Negro e Planície Amazônica.

A região de Manaus está inserida no domínio morfoestrutural do Planalto Dissecado Rio Trombetas-Rio Negro, desenvolvido sobre rochas sedimentares da Formação Alter do Chão (Fig. ), que apresenta alto grau de dissecação, com densidade de drenagem média a alta. Este domínio apresenta-se desnivelado, com altitudes variando entre $200 \mathrm{~m}$ a $350 \mathrm{~m}$ na porção norte, com tendência ao decréscimo de altitude para sul, onde a altimetria varia de $200 \mathrm{~m}$ para até 50m, faixa altimétrica com maior grau de dissecação.

O controle da morfodinâmica é atribuído tanto a processos denudacionais quanto tectônicos (Tricart 1977, Meis 1971, Latrubesse et al. 2000, Horbe et al. 2001), relacionados às flutuações climáticas ocorridas durante o Neógeno tardio, que induziram tanto a lateritização quanto a dissecação do relevo. Na porção norte de Manaus, Horbe et al. (2001) sugeriram a influência de movimentações neotectônicas no modelamento da paisagem, admitindo que os interflúvios tabulares da região sejam sustentados por perfis lateríticos, que configuram platôs, e a evolução destas formas seria associada à atuação de sucessivas fases de remoção e acumulação de parte destes perfis lateríticos desde o Neógeno (Fig. 3.4). Estes autores sugerem que movimentações tectônicas propiciaram o desnivelamento de superfícies geomorfológicas, as quais correlacionam o desenvolvimento de perfis lateríticos. 


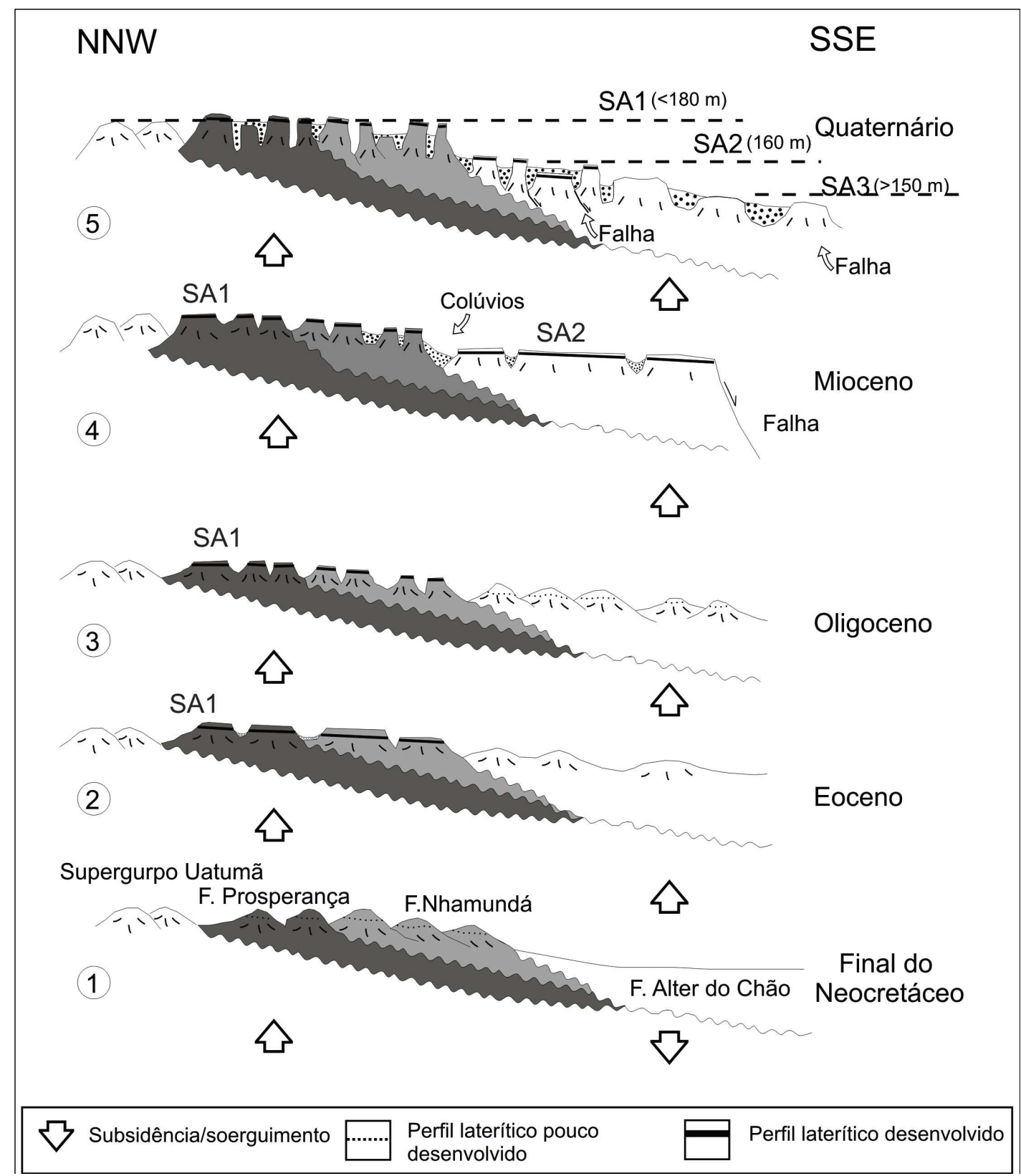

Figura 3.4: Esboço da evolução morfológica entre as regiões de Presidente Figueiredo e Manaus (modificado de Horbe et al. 2001): 1) Deposição da Formação Alter do Chão (Cretáceo) e lateritização da Formação Nhamundá; 2) Soerguimento e aplainamento da Formação Alter do Chão; 3) Dissecação da SA1 e início da lateritização da Formação Alter do Chão, com superposição de processos lateríticos; 4) Formação da SA2, geração do horizonte aluminoso sobre a Formação Alter do Chão, denudação da SA1 e formação de depósitos coluviais; 5) Lateritização incipiente, dissecação atual e configuração do relevo. 


\section{DEPÓSITOS SEDIMENTARES DA REGIÃO DE MANAUS}

Os estudos estratigráficos concentrados na região de Manaus buscaram caracterizar os registros geológicos cenozóicos, formados após a deposição da Formação Alter do Chão, que compreendem depósitos fluviais e coluviais. Os depósitos lacustres e fluviais, de ocorrência restrita, estão mais bem preservados e distribuem-se ao longo rio Amazonas e de tributários de ordem hierárquica inferior (e.g. rios Negro e Cuieiras). Esses depósitos sustentam feições morfológicas de grandes extensões (muitas vezes com dezenas de quilômetros quadrados), delimitáveis em produtos de sensores remotos (fotos aéreas, imagens de radar e de satélites), exemplificadas por barras de canais fluviais que muitas vezes configuram ilhas, terraços fluviais, planícies de inundação, lagos de meandros abandonados (oxbow lakes). Os depósitos coluviais, importantes no entendimento da construção da paisagem, têm ampla ocorrência, porém constituem registros muito fragmentados, com exposições concentradas na porção sul da cidade de Manaus e ao sul da cidade de Presidente Figueiredo.

\subsection{FORMAÇÃO ALTER DO CHÃO: O EMBASAMENTO DOS DEPÓSITOS CENOZÓICOS}

A sucessão aflorante da Formação Alter do Chão na área de estudo é caracterizada por dois pacotes sedimentares distintos, limitados por uma superfície de descontinuidade (S1), ondulada e irregular (Fig. 4.1). A sucessão basal é composta por rochas sedimentares friáveis arenosas de coloração avermelhada, doravante denominada de sucessão 1, e ocorre geralmente em áreas com menores altitudes, enquanto que a sucessão superior, denominada sucessão 2, é constituída por rochas sedimentares areno-argilosas de cor branca, cauliníticas, que ocorrem nas faixas altimétricas mais elevadas. A melhor exposição desta unidade na área ocorre no afloramento localizado no Porto da Estaman, às margens do rio Negro (Fig. 4.1), que consiste em uma exposição contínua, bem preservada e com boa representação do empilhamento estratigráfico. 
ते

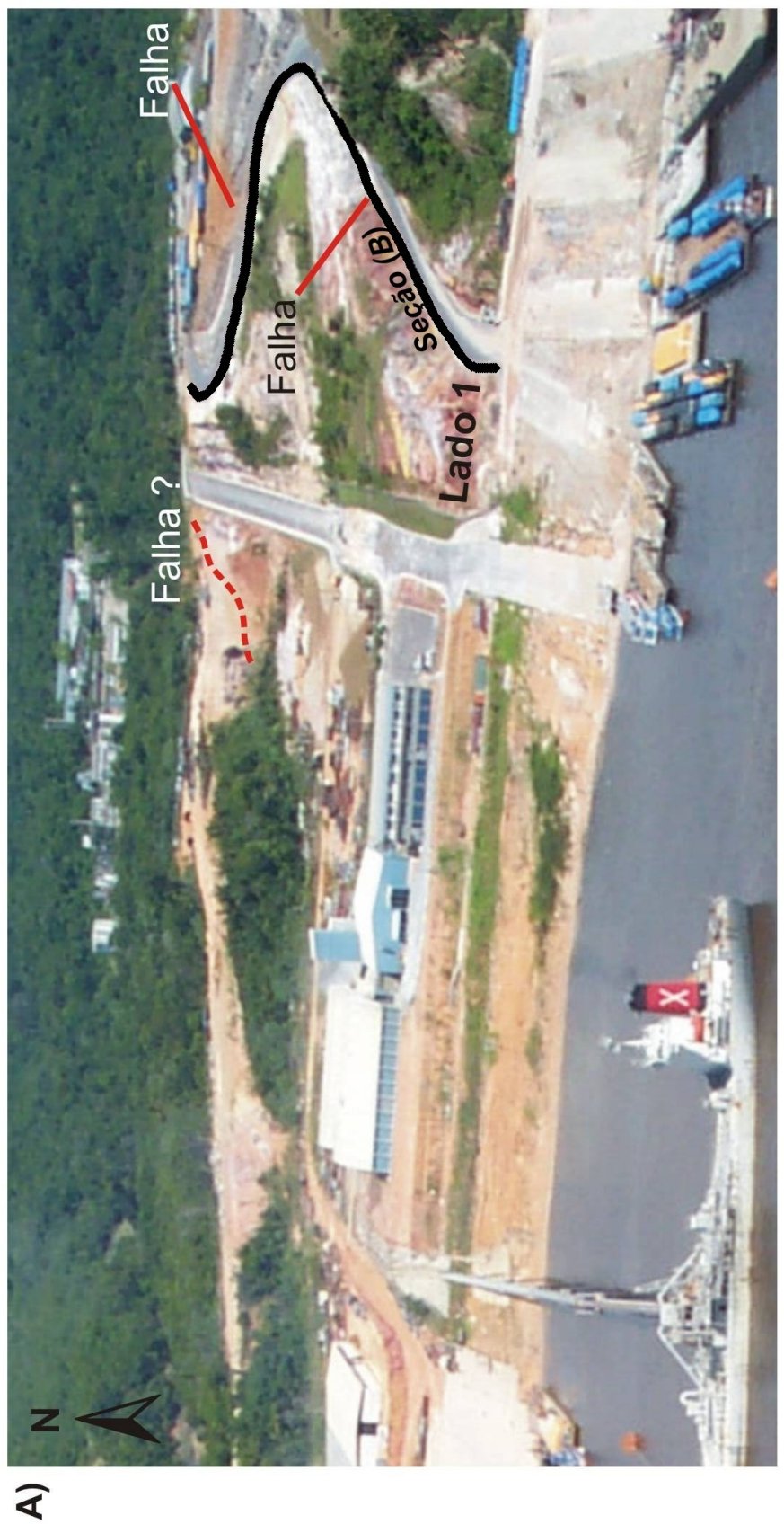

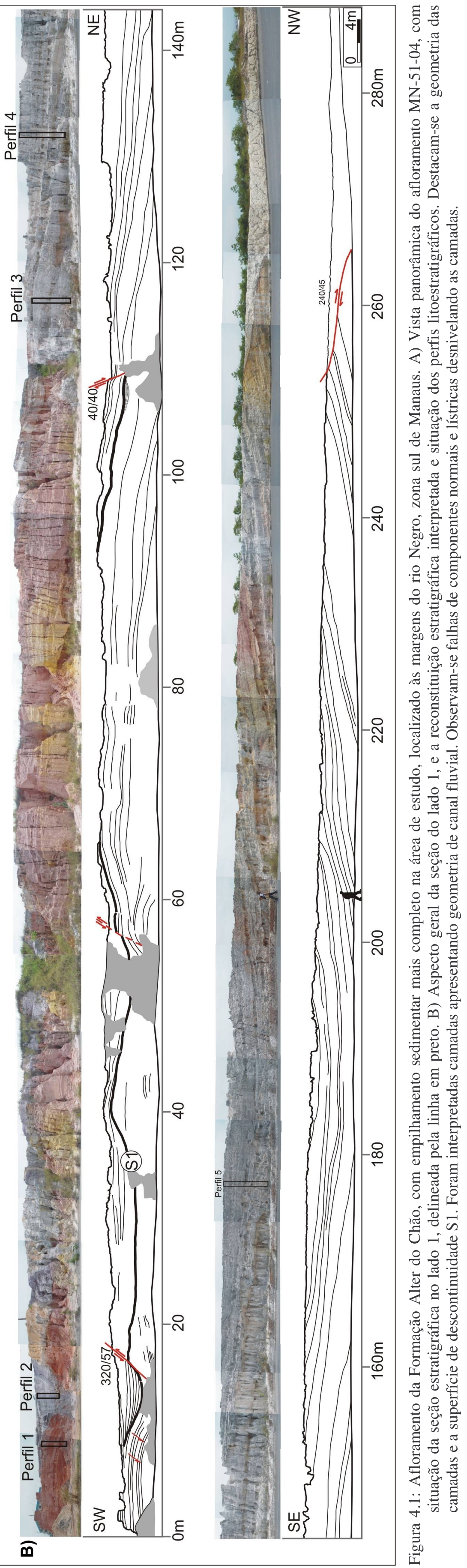


A sucessão 1, que apresenta predominante cor vermelha, é constituída por três litofácies: arenitos, conglomerados e lamitos. Os arenitos possuem estratificações cruzadas acanaladas e tabulares, granulação média a muito grossa, mal selecionados, com grãos angulosos a subangulosos e, ocasionalmente, grânulos de quartzo e líticos (argilitos, siltitos e arenitos). Os conglomerados são maciços e apresentam clastos intraformacionais de argilitos e siltitos, cujos tamanhos variam entre 5 a $12 \mathrm{~cm}$, com coloração avermelhada e matriz arenoargilosa. Os lamitos, de característica cor avermelhada, possuem laminações plano-paralela e gretas de contração. Estruturalmente, a sucessão 1 apresenta deformação sindeposicional, representada por falhas normais, microfalhas, dobras de arrasto, laminações convolutas (Figs. 4.2, 4.3 e 4.4). Falhas normais representantes de uma fase posterior à sedimentação estão registradas nas exposições estudadas (Figs. 4.2, 4.4 e 4.5).

A sucessão 2 (Figs. 4.1, 4.3 e 4.5) é constituída por arenitos finos, arenitos médios a grossos, arenitos grossos mal-selecionados, lamitos e lentes de argila, de coloração cinzaesbranquiçada, bioturbados, com estratificações cruzadas tabulares. Esta sucessão apresentase afetada por falhas normais e juntas (Figs. 4.1 e 4.3). O topo da sucessão 2 é marcado pala presença de linhas de pedras, solos, perfis lateríticos ou podem mostrar-se afetados por intemperismo atual (Fig. 4.1, 4.5 e 4.6). As linhas de pedras são constituídas por nódulos ferruginosos, concrecionários e apresentam espessura delgada. Os solos geralmente correspondem a oxissolos de coloração amarelada, contendo grânulos de quartzo dispersos.

Sobre camadas avermelhadas de siltitos, arenitos grossos e arenitos bem silicificados (correlacionáveis ao "Arenito Manaus"), pertencentes à Formação Alter do Chão, ocorrem pacotes espessos de arenitos grossos a médios, maciços, com acamamento incipiente, de coloração laranja-amarelado, limitados na base por uma superfície de descontinuidade denominada S2 (Figs. 4.6 e 4.7). 

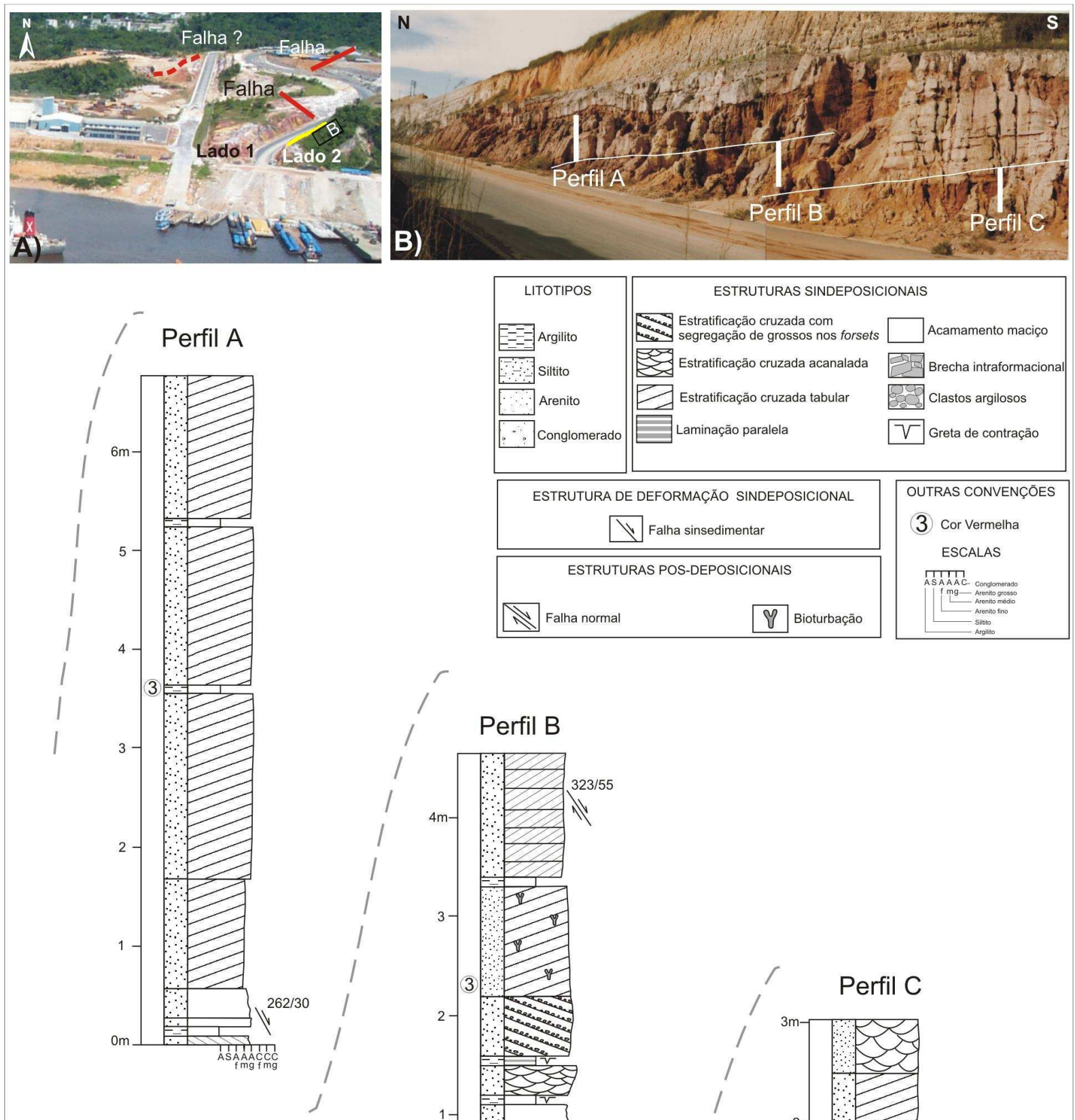

\section{Perfil B}
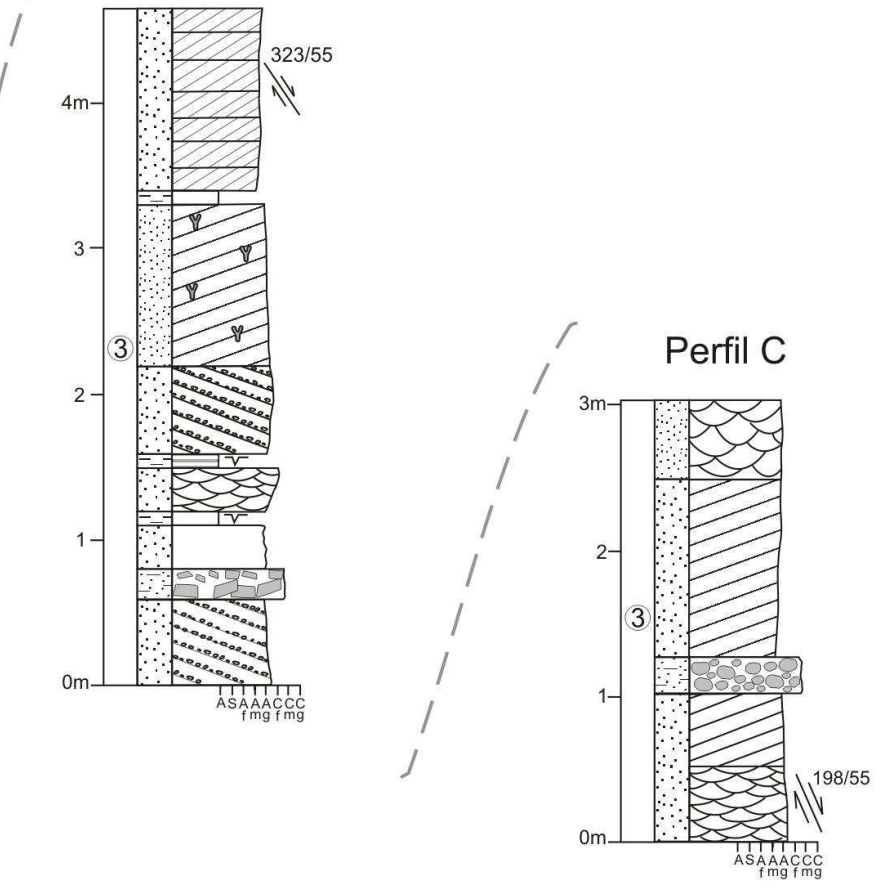

Figura 4.2: Afloramento da Formação Alter do Chão, localizado às margens do rio Negro, zona sul de Manaus. A) Vista panorâmica do afloramento MN-51-04, com localização do detalhe em B. B) Aspecto geral da sucessão 1 e a localização dos perfis, na seção estratigráfica do Lado 2. C) Perfis litoestratigráficos da sucessão 1. 


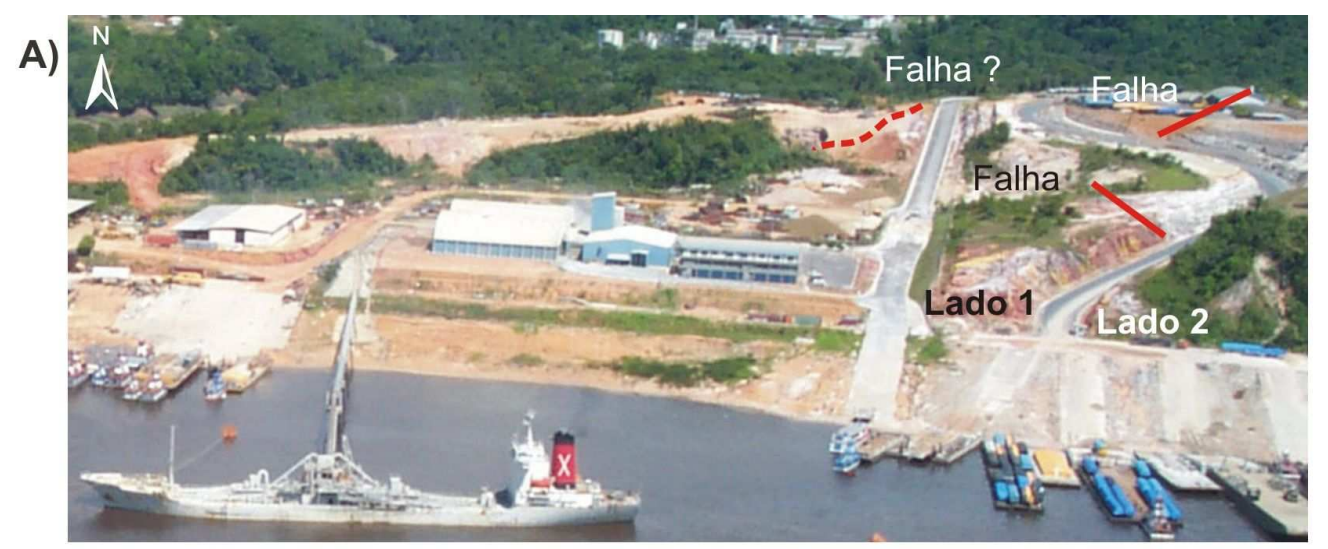

B)
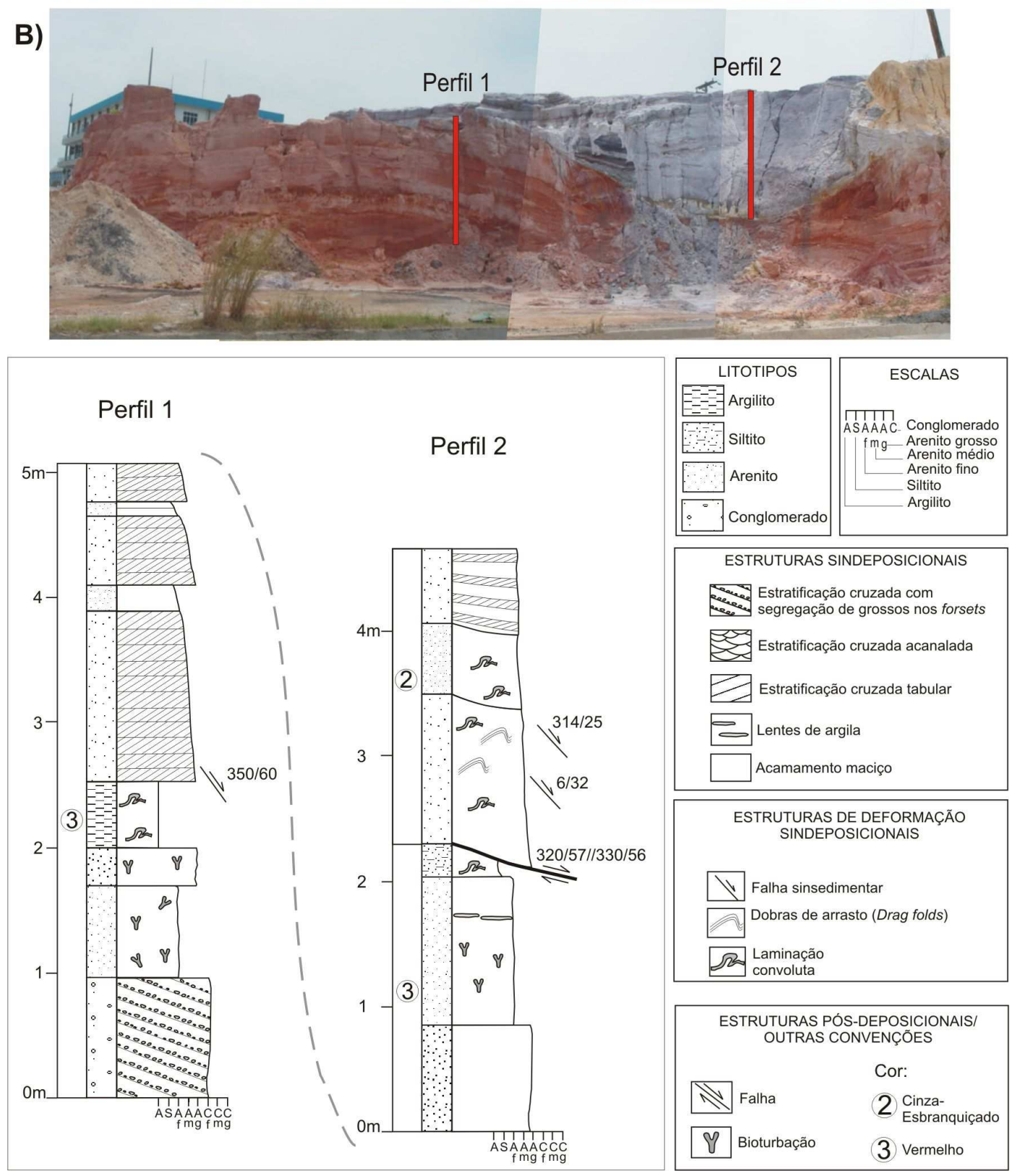

Figura 4.3: Afloramento da Formação Alter do Chão, localizado às margens do rio Negro, ao sul de Manaus. A) Vista panorâmica do afloramento MN-51-04. B) Contato entre a sucessão 1 e a sucessão 2, na seção estratigráfica do Lado 1, e a localização dos perfis. C) Perfis litoestratigráficos: o Perfil 1 pertence à sucessão 1 e o Perfil 2 é representativo da sucessão 2. 


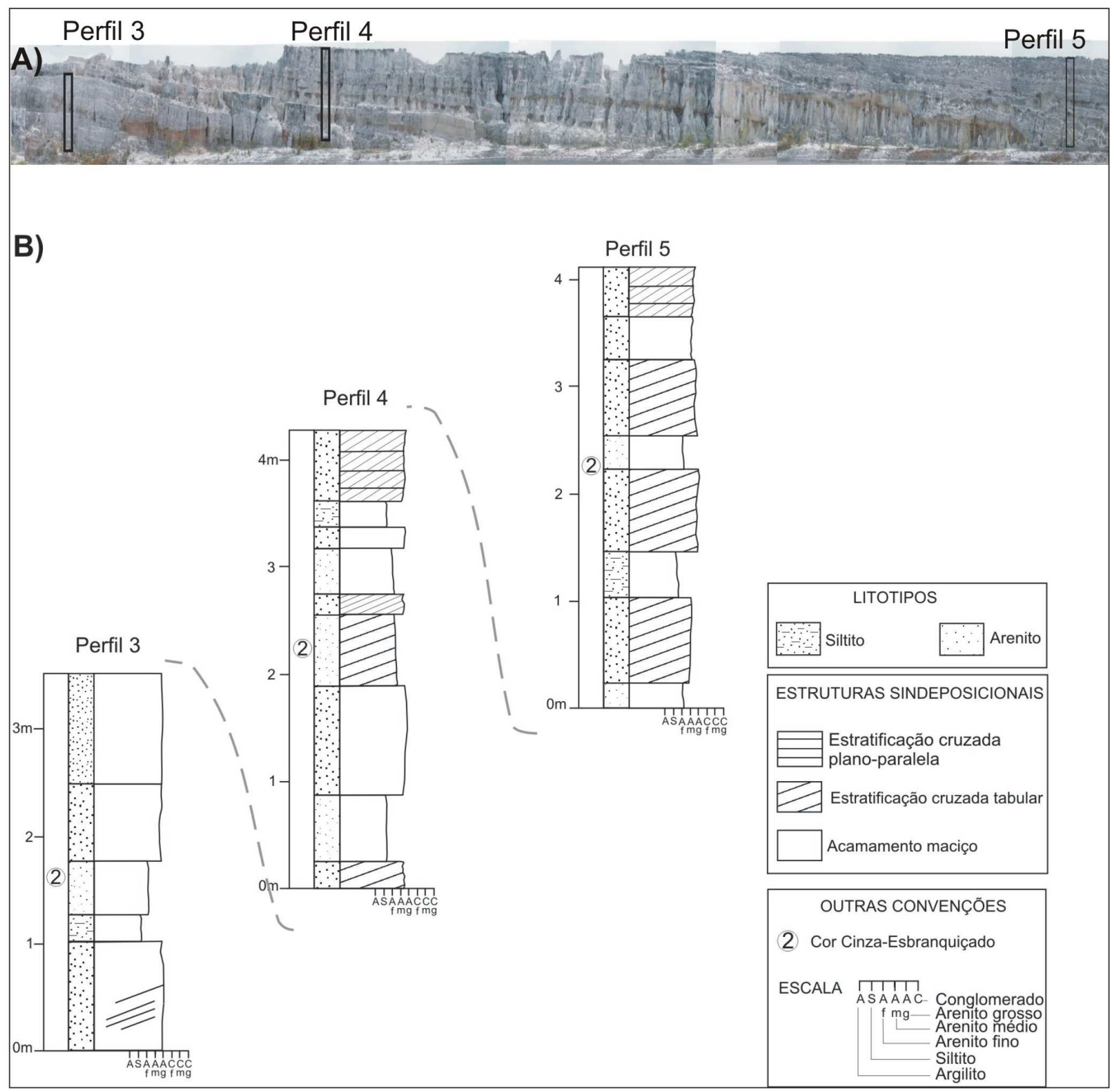

Figura 4.4: Afloramento da Formação Alter do Chão (MN-51-04), localizado às margens do rio Negro, ao sul de Manaus. A) Localização dos perfis na secção estratigráfica do Lado 1. B) Perfis litoestratigráficos representativos da sucessão 2 . 


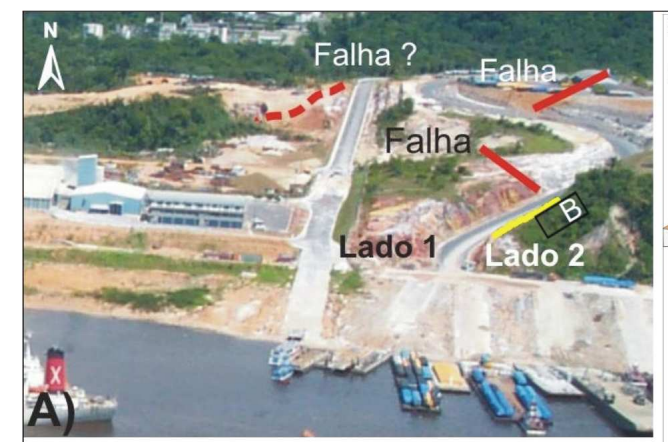

\section{C)}
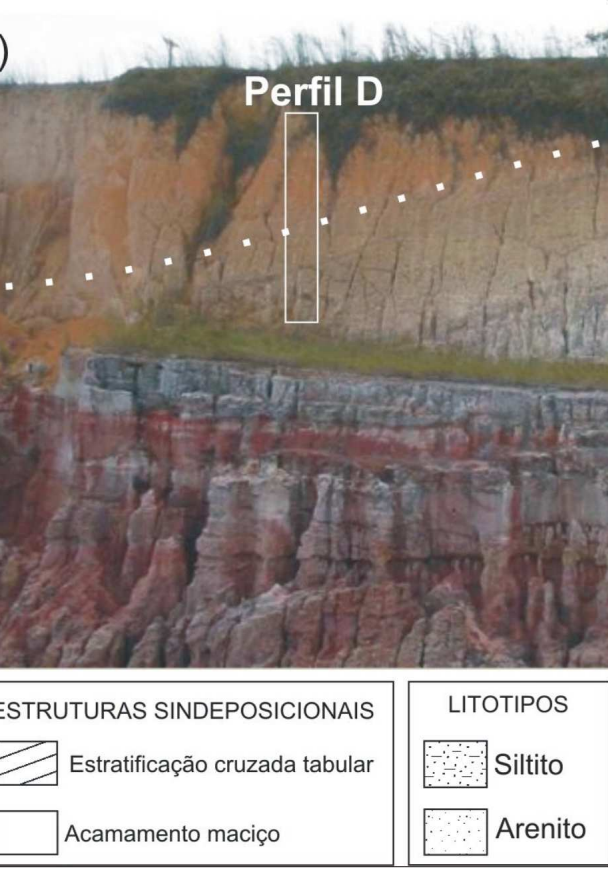

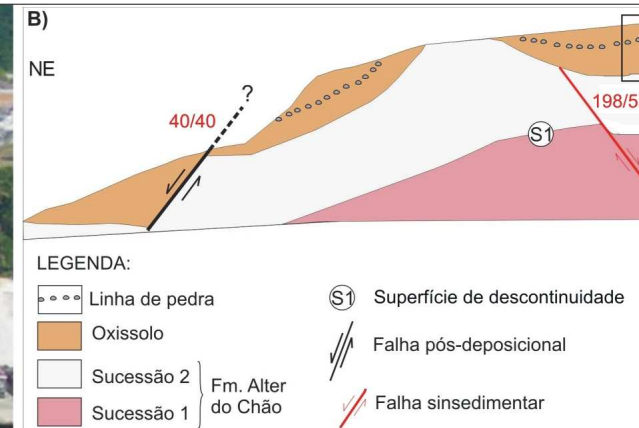

(51) Superficie de descontinuidade

/// Falha pós-deposicional

/ Falha sinsedimentar

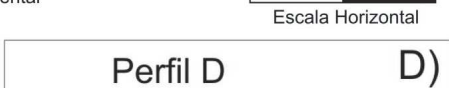

Perfil D

D)

sW

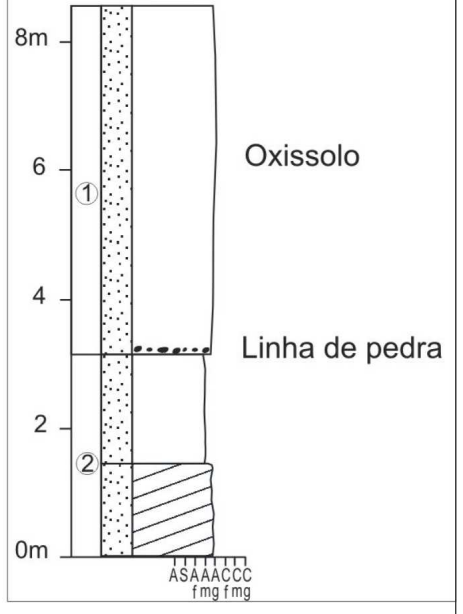

OUTRAS CONVENÇÕES
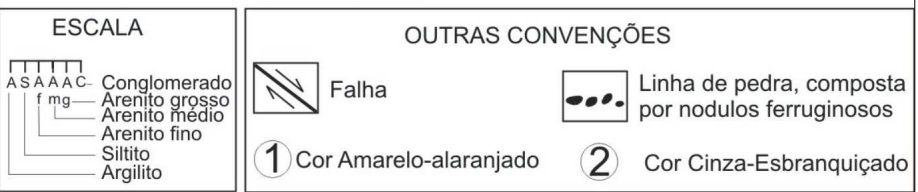

Figura 4.5: Afloramento da Formação Alter do Chão, localizado às margens do rio Negro, zona sul de Manaus. A) Vista panorâmica do afloramento MN-51-04, com situação da seção estratigráfia do Lado 2, delineada pela linha em amarelo. B) Desenho esquemático da seção estratigráfica do Lado 2 e localização da foto de detalhe. C) Aspecto geral do topo da sucessão 2, com deformação das camadas. D) Perfil litoestratigráfico do topo da sucessão 2, que apresenta linha de pedra formada por nódulos ferruginosos e solo tipo oxissolo. 

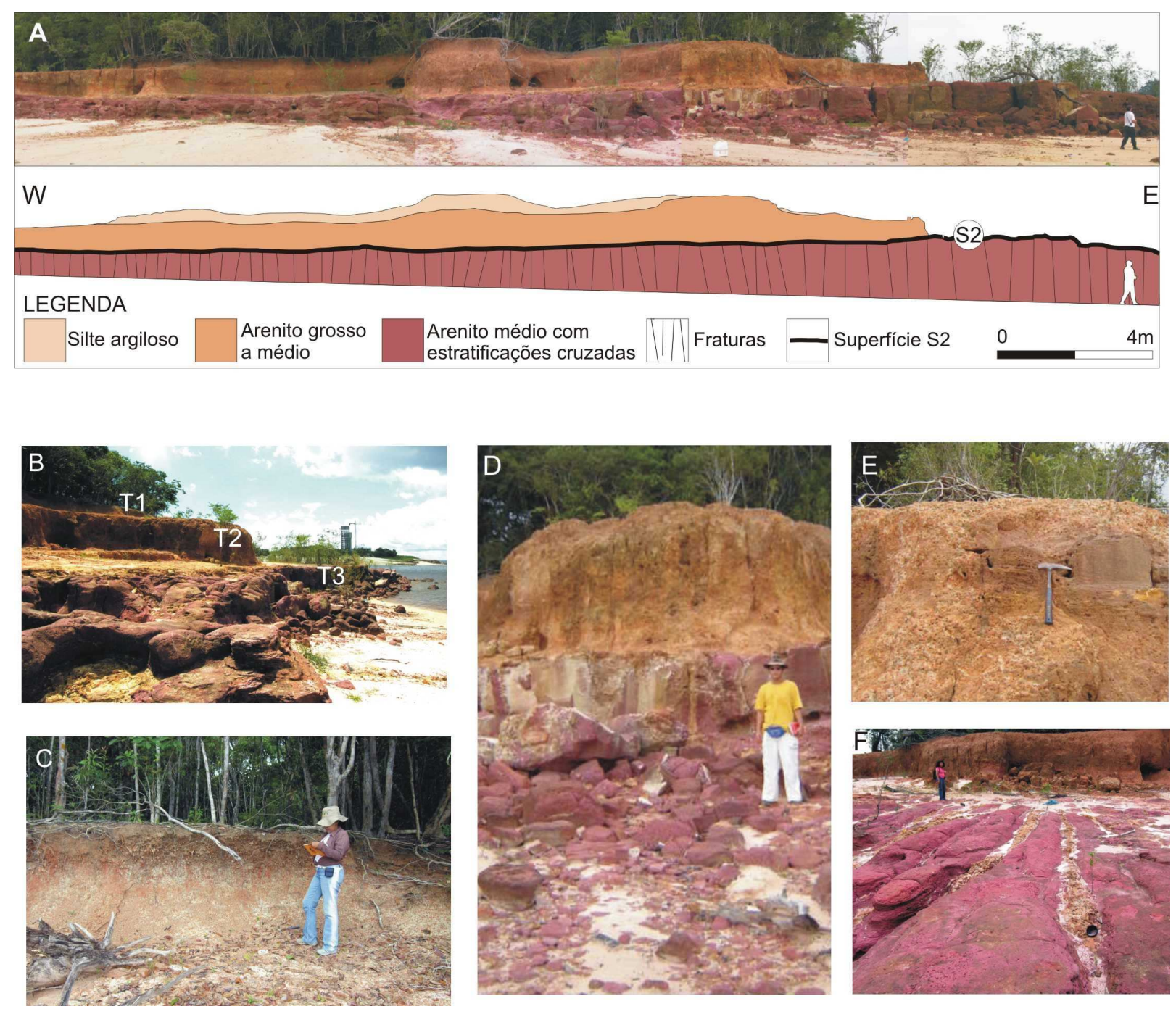

Figura 4.6: Seção estratigráfica MN-02-05, localizada à margem esquerda do rio Negro. A) Vista geral do afloramento, com representação da seção. Destaca-se a superfície de descontinuidade S2, que limita um pacote de arenitos bem silicificados avermelhados, com fraturas subverticais, da sucessão sedimentar superior do afloramento, que pode constituir uma unidade diferenciada da Formação Alter do Chão, provavelmente paleógena. B) Observam-se três níveis de terraços erosivos T1, T2 e T3, cuja relação morfoestratigráfica indica que T3 é o mais recente; T2 é o intermediário e T1 corresponde ao nível mais antigo. C) do topo da seção, constituído por sedimentos fluviais síltico-argilosos provavelmente holocenos, representando os depósitos mais novos da área. D) Aspecto geral do contato entre os arenitos médios avermelhados e o pacote sedimentar intermediário. E) Detalhe do pacote intermediário constituído por arenitos grossos a médios, maciços, com intensa bioturbação, apresentando uma lâmina de arenito ferruginizado entre o pacote sedimentar. F). Fraturas subverticais observadas em planta, desenvolvidas somente nos arenitos avermelhados. 


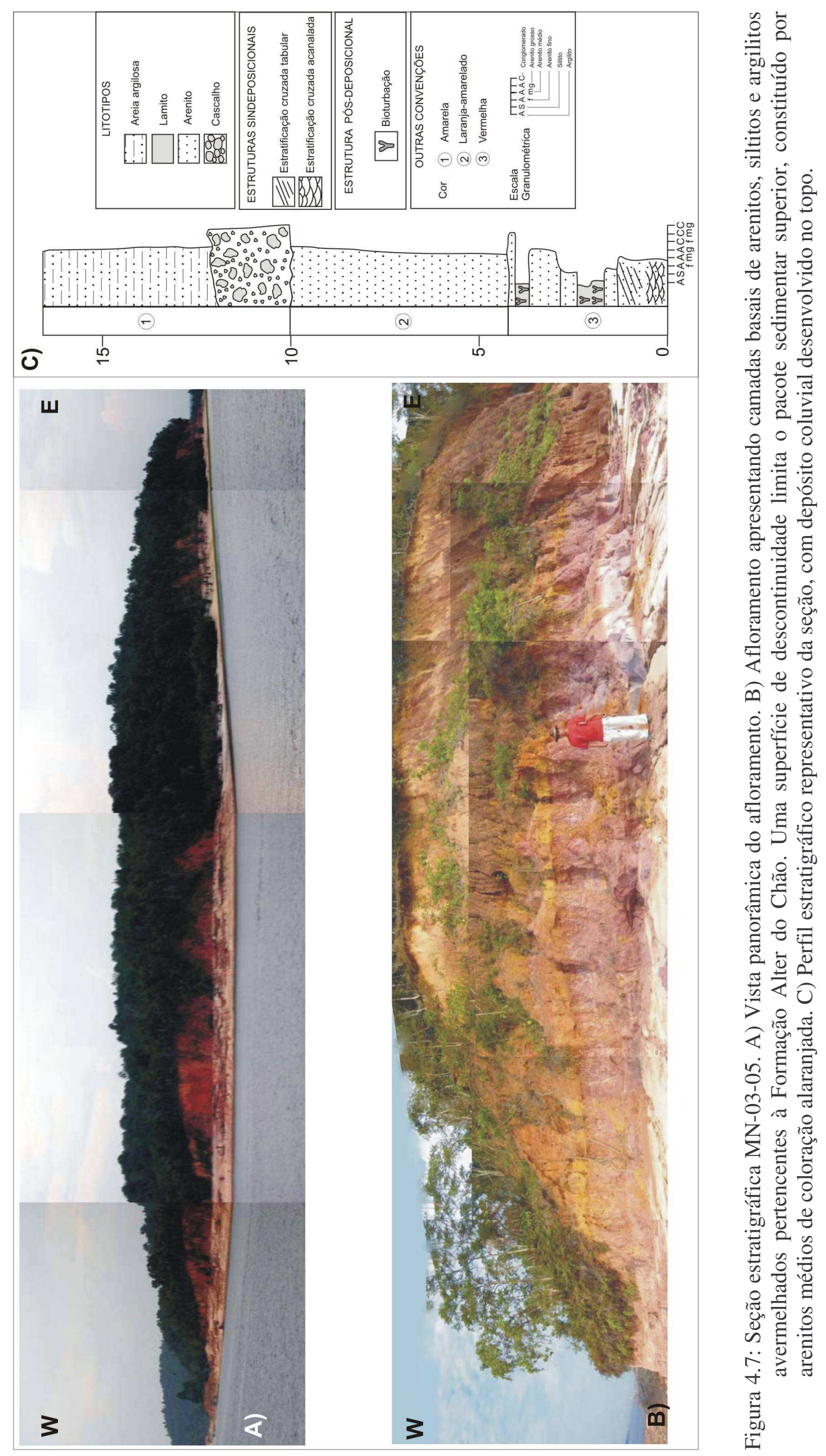




\subsubsection{CONTEXTO DEPOSICIONAL}

As sucessões sedimentares foram depositadas em ambiente fluvial com diferentes condições de energia. Os arenitos, conglomerados e brechas intraformacionais que caracterizam a sucessão 1 (basal), são associados a depósitos de canal desenvolvidos em ambiente de alta energia, sob regime de fluxo superior, possivelmente ambiente fluvial entrelaçado, conforme já sugerido por Nogueira et al. (1999) e Vieira (1999). Os arenitos maciços, desenvolvidos sobre camadas deformadas, podem estar associados à liqüefação local ou obliteração das estruturas por evento posterior (tectônica, intemperismo ou silicificação).

A sucessão 2 (superior) apresenta características de ambiente fluvial meandrante, onde os arenitos e lamitos com laminação plano-paralela e gretas de contração podem ser interpretados como depósitos de planície de inundação, lacustres ou meandros abandonados (lagos tipo oxbow) relacionados a processos de decantação. Os arenitos médios a grossos, com estratificações cruzada acanalada e tabular, foram depositados sob regime de fluxo inferior, com atuação de processos de migração de barras de canal. Esta interpretação também tem sido sugerida por trabalhos anteriores (Nogueira et al. 1999).

Os arenitos maciços, de coloração laranja-amarelada, sobrepostos à superfície de descontinuidade S2, que possivelmente pode limitar um evento deposicional posterior a Formação Alter do Chão; desta forma, estes arenitos poderiam estar associados à Formação Novo Remanso (Rozo et al. 2005), posicionado no Mioceno. Outra possibilidade é que se trata de camadas associadas a uma mudança de fácies do sistema deposicional da Formação Alter do Chão, onde as estruturas originais poderiam ter sido obliteradas por ação intempérica, pedogenética ou diagenética. 


\subsection{DEPÓSITOS FLUVIAIS NEÓGENOS}

Os depósitos aluviais são constituídos por cascalhos, areias e argilas (Figs. 4.8, 4.9 e 4.10). Estes depósitos apresentam ocorrência restrita ao longo dos rios de grande porte, em fundo de vales ou de lagos. Consistem essencialmente em sucessões sedimentares com espessura na ordem de 1m, constituídas por arenitos finos, arenitos médios a grossos, sedimentos argilosos e siltosos.

A predominância de argilas maciças a incipientemente laminadas sugere deposição a partir de processos de suspensão provavelmente relacionados à planície de inundação. A cor intensa vermelha, por vezes mosqueada, pode ser indicativa de processo de oxidação da matéria orgânica, provavelmente por exposição subaérea anterior aos processos erosivos impressos durante a migração de canal, sugerido pela base erosiva da unidade arenosa sobreposta. Embora as estruturas sedimentares estejam parcialmente obliteradas, a ocorrência de arenitos médios a grossos com incipiente estratificação plano-paralela, podem estar relacionadas à atuação de regime de fluxo superior, provavelmente associados a depósitos de barras longitudinais ou lençol de areia em canal fluvial (Harms et al. 1982). O limite do canal muitas vezes é marcado pela ocorrência de superfícies de falhas lístricas, indicando processos de solapamento de banco marginal (cut bank) e de "terra caída". A ocorrência destes depósitos na porção mais interna do Rio Cuieiras, distante dos principais sítios de deposição dentro dos grandes rios, é sugestiva de condições de preservação em áreas próximas aos interflúvios. 

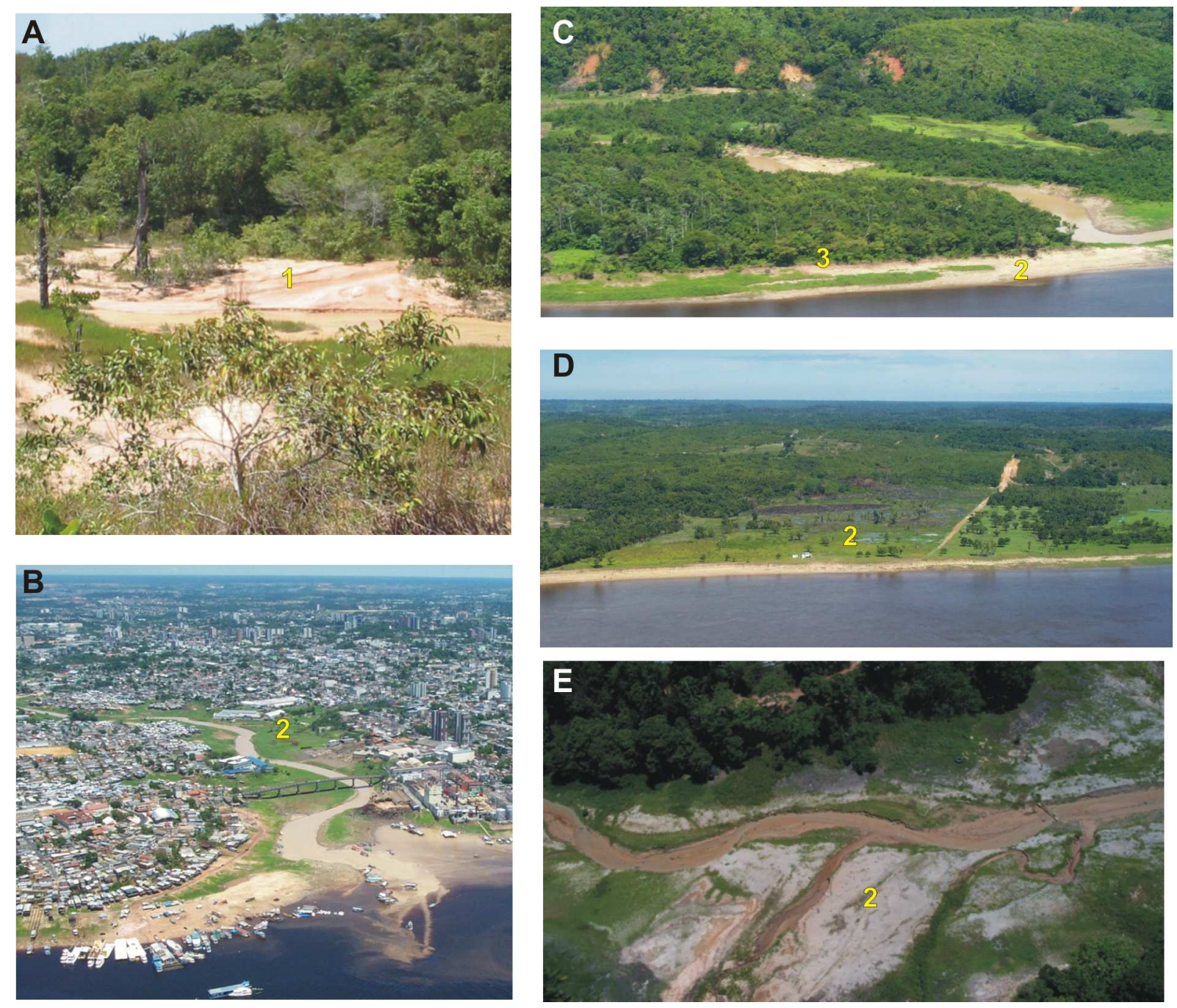

Figura 4.8: Formas de relevo associadas aos depósitos aluviais da região. A) Vale colmatado (1), registrado na zona leste de Manaus. B) Desembocadura do igarapé São Raimundo, onde se observa planície de inundação atual influenciada pela dinâmica fluvial do rio Negro (2). C) Margem esquerda do rio Negro, no extremo sudeste de Manaus, com exemplos de terraço fluvial (3), com altura média de $2 \mathrm{~m}$, e planície de inundação atual (2). D) Lago do Puraquequara, com planície de inundação atual (2). E) Planície de inundação atual (2) em rio tributário da margem esquerda do rio Solimões. 


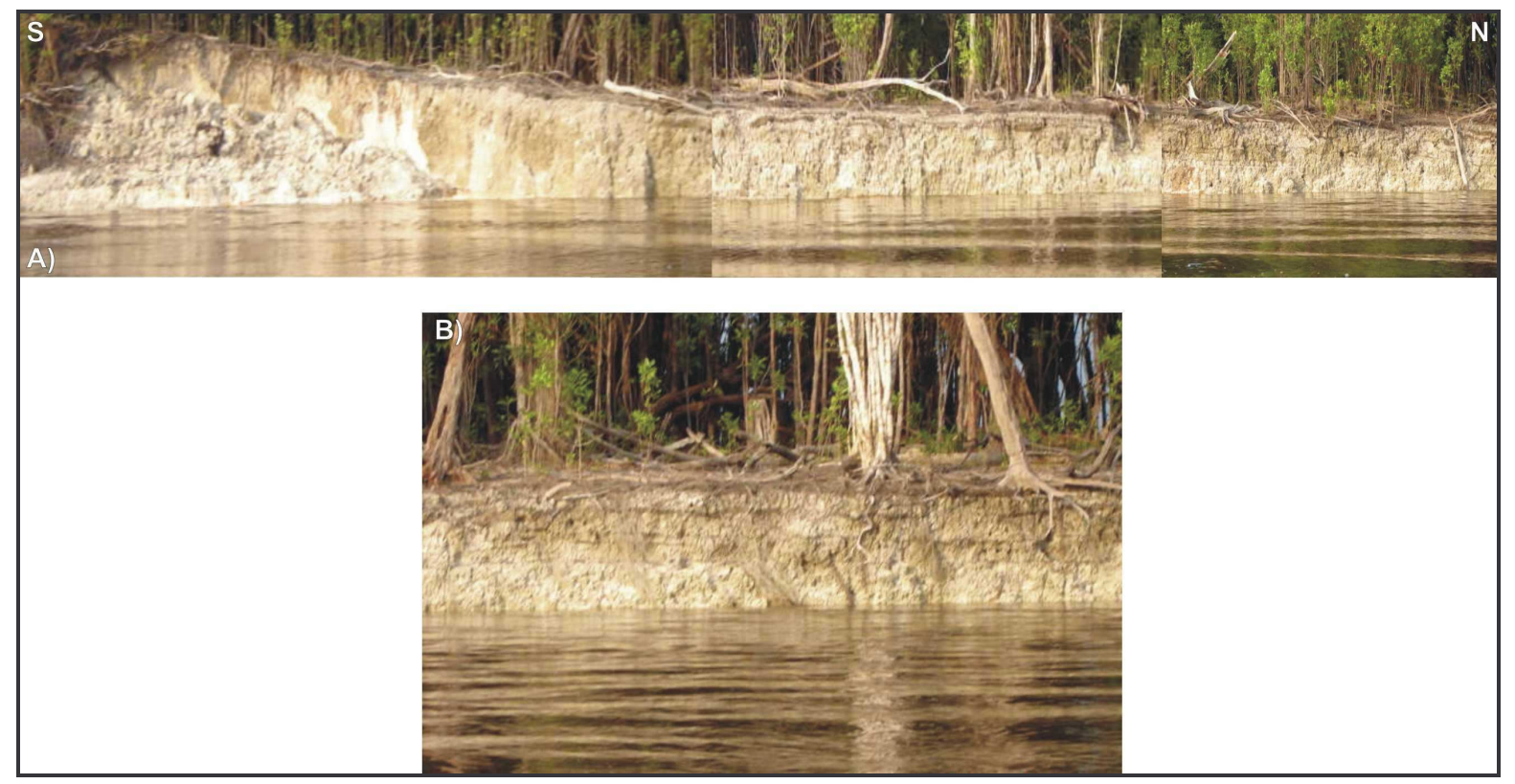

Figura 4.9: Depósitos sedimentares arenosos que configuram terraços fluviais ao longo do rio Cueiras. A) Aspecto geral da exposição, com disposição subhorizontal das camadas de arenitos. B) Detalhe do afloramento, onde se observa nível delgado rico em matéria orgânica, intercalado com arenitos (MN-P1-05).

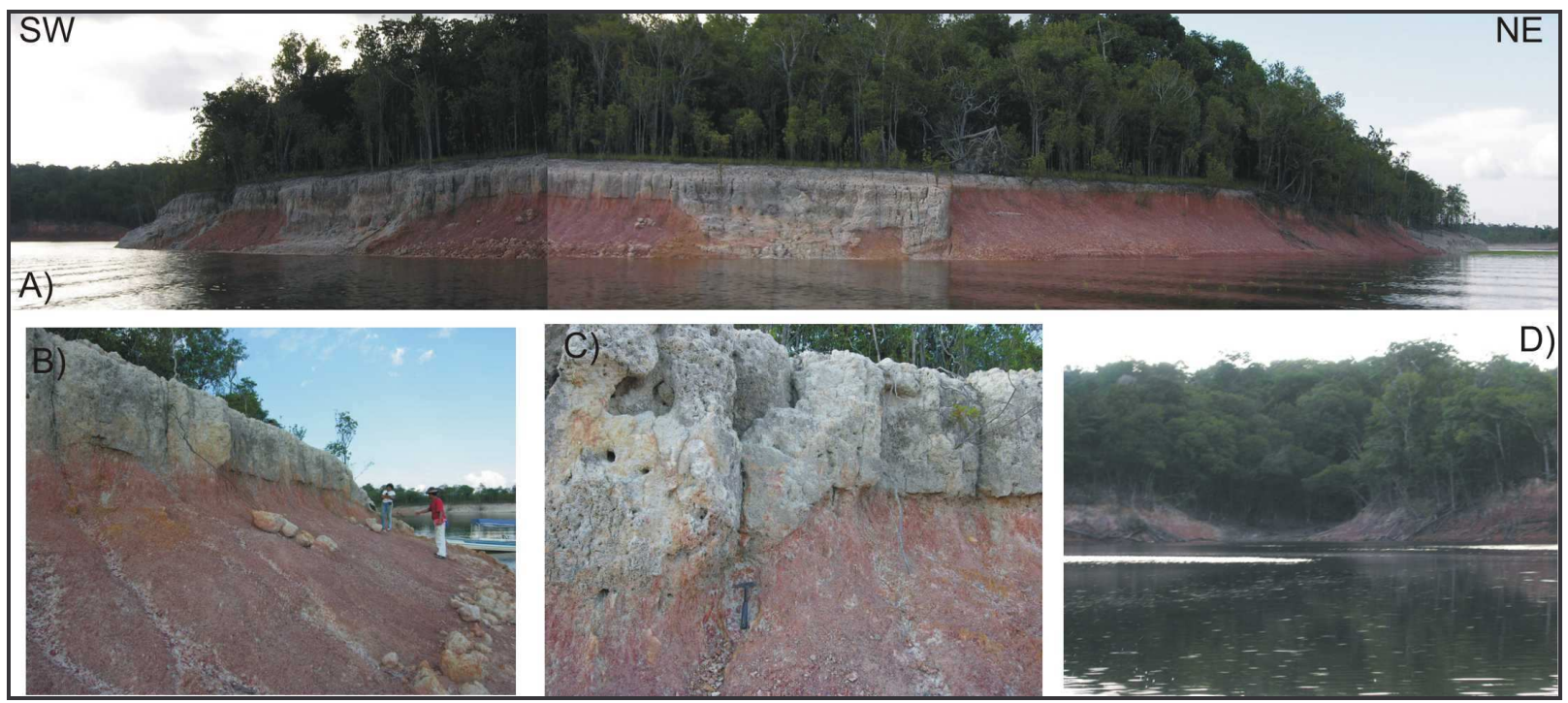

Figura 4.10: Seção estratigráfica MN-06-05, que representa duas unidades neógenas ocorrentes no rio Cuieiras. A) Vista geral da seção, localizada em um divisor às margens do rio, com depressões em "U" escavadas no pacote sedimentar de coloração avermelhada constituído por areias finas a siltes; este encontra-se preenchido por camadas horizontais de arenitos médios de coloração branco-acinzentado, com grânulos de quartzo. B) Contato entre as areias finas a siltes vermelhas e os arenitos médios branco-acinzentado. C) Detalhe da base da depressão preenchida por arenitos branco-acinzentados. D) Canal de um tributário do rio Cuieiras, com vale em forma de "U", que fica totalmente exposto no período de vazante. 


\title{
4.3. A GÊNESE DOS DEPÓSITOS COLUVIAIS NA REGIÃO DE MANAUS, NORDESTE DO ESTADO DO AMAZONAS
}

Submetido à Revista Brasileira de Geociências

\author{
Roseane Ribeiro Sarges ${ }^{l}$ \\ Claudio Riccomini ${ }^{2}$ \\ Afonso César Rodrigues Nogueira ${ }^{3}$
}

\begin{abstract}
${ }^{1}$ Programa de Pós-graduação em Geoquímica e Geotectônica, Instituto de Geociências, Universidade de São Paulo, Rua do Lago, 562, 05508-080, São Paulo, SP, Brasil, rrsarges@usp.br;

${ }^{2}$ Departamento de Geologia Sedimentar e Ambiental, Instituto de Geociências, Universidade de São Paulo, Rua do Lago, 562, 05508-080, São Paulo, SP, Brasil, riccomin@usp.br; bolsista de produtividade em pesquisa do CNPq;

${ }^{3}$ Centro de Geociências, Universidade Federal do Pará, CP 1611, 06675-900, Belém, Pará, Brasil,anogueira@ufpa.br; bolsista de produtividade em pesquisa do CNPq.
\end{abstract}

\section{RESUMO}

Os depósitos coluviais da região compreendida entre Manaus e Presidente Figueiredo, Amazonas, constituem importantes registros sobre a história da denudação e as mudanças da paisagem da Amazônia central. Estes depósitos coluviais homogêneos, friáveis e intemperizados, ocorrem sobrepostos a rochas fanerozóicas da Bacia do Amazonas. O estudo sedimentológico-estratigráfico em combinação com a análise geomorfológica da região entre as cidades de Presidente Figueiredo e Manaus permitiu individualizar quatro tipos de depósitos coluviais (DC), depositados sob ação combinada de processos gravitacionais e fluxos torrenciais, em condições de alta energia, denominados de DCA, DCB, DCC e DCD. As fácies predominantes nestes depósitos são: cascalho maciço sustentado pela matriz (Cmsm) ou por clastos (Cmsc), com seixos de lamito semi-flint (Cmsf), além de cascalhos com gradação inversa (Cgi) e areias maciças (Am). O DCA exibe intervalos bem 
diferenciados pela textura e granulação, correlacionados a múltiplos eventos de coluviação, associado à denudação de platôs com perfis lateríticos bauxítico-ferruginosos desenvolvidos sobre as rochas siliciclásticas siluro-devonianas do Grupo Trombetas. A formação destes perfis lateríticos bauxíticos está associada ao desenvolvimento da superfície geomorfológica formada no Neocretáceo-Paleógeno, sobre a qual está desenvolvido o DCA. Os depósitos coluviais DCB, DCC e DCD recobrem a superfície geomorfológica mais nova, formada no Oligoceno-Mioceno, associada aos platôs sustentados por perfis lateríticos ferruginosos desenvolvidos sobre a Formação Alter do Chão. O DCB foi construído a partir de detritos provenientes de nível com argila semi-flint da Formação Alter do Chão, e o DCC é produto da ressedimentação de antigos depósitos coluviais. O DCD reúne cascalhos com fragmentos de crostas de perfis lateríticos imaturos e paleopavimentos residuais. A idade destes depósitos foi inferida usando as relações com as superfícies geomorfológicas da região. Desta forma, o DCA pode ter sido formado no Plio-Pleistoceno, enquanto os demais depósitos coluviais podem ter iniciado a sua deposição no Pleistoceno tardio. O espaço de acomodação gerado para os depósitos coluviais mais antigos (DCA) foi influenciado por tectônica, em contraste com a deposição coluvial mais jovem (DCD), que ocorreu provavelmente após a última fase de movimentação neotectônica.

Palavras-chave: Depósitos coluviais, processos sedimentares, Amazônia central.

\begin{abstract}
Colluvial deposits are an important record of the denudation history and landscape changes of the central Amazonian region. These homogeneous, friable and weathered deposits overlap the generally weathered Phanerozoic siliciclastics rocks. Sedimentologic and
\end{abstract}


stratigraphic data in combination with geomorphologic analysis carried out in the region between the cities of Presidente Figueiredo and Manaus, define four types of colluvial deposits, DCA, DCB, DCC and DCD. The colluvial deposits deposited were with gravitational processes associates with torrential flows, in high energy environmental conditions. The predominant facies are massive, matrix-supported gravel $(\mathrm{Cmsm})$ or clastsupported gravel (Cmsc), with pebbles of semi-flint mudstone (Cmsf), inverse grading (Cgi) and massive sands (Am). The DCA exhibits well defined horizons differentiated by texture and granulation and correlated with multiple colluvial events subsequent to denudation of plateaus with bauxitic-ferruginous lateritic profiles. This lateritic profile is correlated with a geomorphological surface of Neocretaceous-Paleogene age and related to the formation of bauxitic lateritic profiles, when overlying the DCA. The colluvial deposits B, C and D overlie an Oligocen-Miocene denudation surface composed of plateaus supported by a ferruginous lateritic profile developed on Cretaceous siliciclastic rocks of the Alter do Chão Formation. The DCB was built from clasts of a semi-flint clay level of the Alter do Chão Formation, and the DCC from resedimentation of older colluvial deposits. The DCD includes gravels and crust fragments of immature lateritic profile as well as stone layers. The age of these deposits was inferred on the basis of the geomorphological surface recognized in the Amazonia region. The DCA was correlated to the Pliocene-Pleistocene, while the deposition of DCB, DCC and DCD initiated in the late Pleistocene. The accumulation space for the deposition of the DCA was influenced by tectonic factors. In contrast, the deposition of younger colluviums (DCD) probably occurred after the last phase of neotectonic movements.

Keywords: Colluvial deposits, sedimentary processes, central Amazonia. 


\section{INTRODUÇÃO}

Depósitos coluviais são corpos sedimentares confinados e associados a superfícies topográficas inclinadas, tais como escarpas, encostas e sopés de colinas e montanhas (Bigarella \& Mousinho 1965, Blikra \& Nemec 1998). A geração deste tipo de depósito envolve a produção de detritos, por ação do intemperismo e erosão, com reduzido transporte do material residual, onde as partículas são deslocadas individualmente ou por movimentos de massa, impulsionadas pela ação da gravidade e fluxos superficiais, sendo depositadas em superfícies suavemente côncavas ou pequenas depressões, tais como ravinas e voçorocas (Selby 1994).

A baixa preservação de depósitos coluviais no registro geológico decorre do reduzido espaço de acomodação das encostas e da alta taxa de denudação a que são submetidas (Crowley 1984). Esses depósitos podem, ainda, ser homogeneizados quando submetidos a intensos processos de lateritização e pedogênese, como se verifica na Amazônia, o que geralmente confere aspecto homogêneo e friável, além de eliminar por oxidação materiais propícios para datação (matéria orgânica e palinomorfos), mascarando os critérios diagnósticos para seu reconhecimento.

No noroeste da Bacia do Amazonas, os depósitos arenosos aflorantes foram correlacionados inicialmente aos "sedimentos Barreiras", de idade Neógena (Moura 1938, Oliveira \& Leonardos 1943), por considerarem a uma possível idade neógena para os depósitos superficiais da região. Esta correlação foi posteriormente descartada, após estudos bioestratigráficos baseado na datação de pólens, indicarem idade cretácea para os depósitos em subsuperfície da Formação Alter do Chão (Daemon 1975, Dino et al. 1999), idade que foi extrapolada indiscriminadamente para os depósitos de superfície da região, em mapeamentos geológicos posteriores. A falta de estudos estratigráficos de detalhe, a ausência de material para a datação, a difícil distinção entre sedimentos recentes e os depósitos intemperizados da 
Formação Alter do Chão foram fatores que limitaram e dificultaram o reconhecimento e a datação de depósitos pós-cretáceos.

Recentemente, investigações estratigráficas em sedimentos fluviais e lacustres da região têm possibilitado a definição de depósitos neógenos (Campbell Jr. et al. 2001, Soares \& Riccomini 2003, Rossetti et al. 2005, Rozo et al. 2005, Nogueira et al. 2006). Entretanto, estas investigações têm se concentrado nas calhas dos grandes rios da região, enquanto que os estudos sobre os sedimentos coluviais presentes em situação de interflúvios, gerados por mecanismos de denudação nas áreas dos divisores de drenagens (platôs), são ainda incipientes (Horbe et al. 2001, Silva 2005). Neste trabalho, foram identificados e classificados depósitos coluviais que recobrem rochas fanerozóicas desde a borda norte da Bacia do Amazonas até a região de Manaus (Fig. 4.11). Esta investigação permitiu caracterizar os processos e a origem destes depósitos e contextualizá-los num modelo de evolução da paisagem desta parte da Amazônia durante o Pleistoceno-Holoceno.

\section{CONTEXTO GEOLÓGICO}

A borda norte da Bacia do Amazonas, na região de Presidente Figueiredo, é caracterizada por rochas sedimentares das formações Nhamundá, Pitinga e Manacapuru, do Paleozóico inferior (Nogueira et al. 2003), e pela Formação Alter do Chão, do Cretáceo Superior (Nogueira et al. 1999). Os arenitos e lamitos da Formação Nhamundá são sobrepostos em contato brusco com os folhelhos da Formação Pitinga e folhelhos e arenitos da Formação Manacapuru. Estas unidades são recobertas discordantemente pelos arenitos cauliníticos, siltitos e lamitos da Formação Alter do Chão, que se estendem para a região de Manaus (Fig. 4.11). Arenitos ferruginosos e lamitos miocenos da Formação Novo Remanso distribuem-se descontinuamente e discordantemente sobre a Formação Alter do Chão, 
próximo às margens do rio Amazonas (Rozo et al. 2005). Depósitos recentes de areias e lamas formam barras, canais e lagos fluviais.

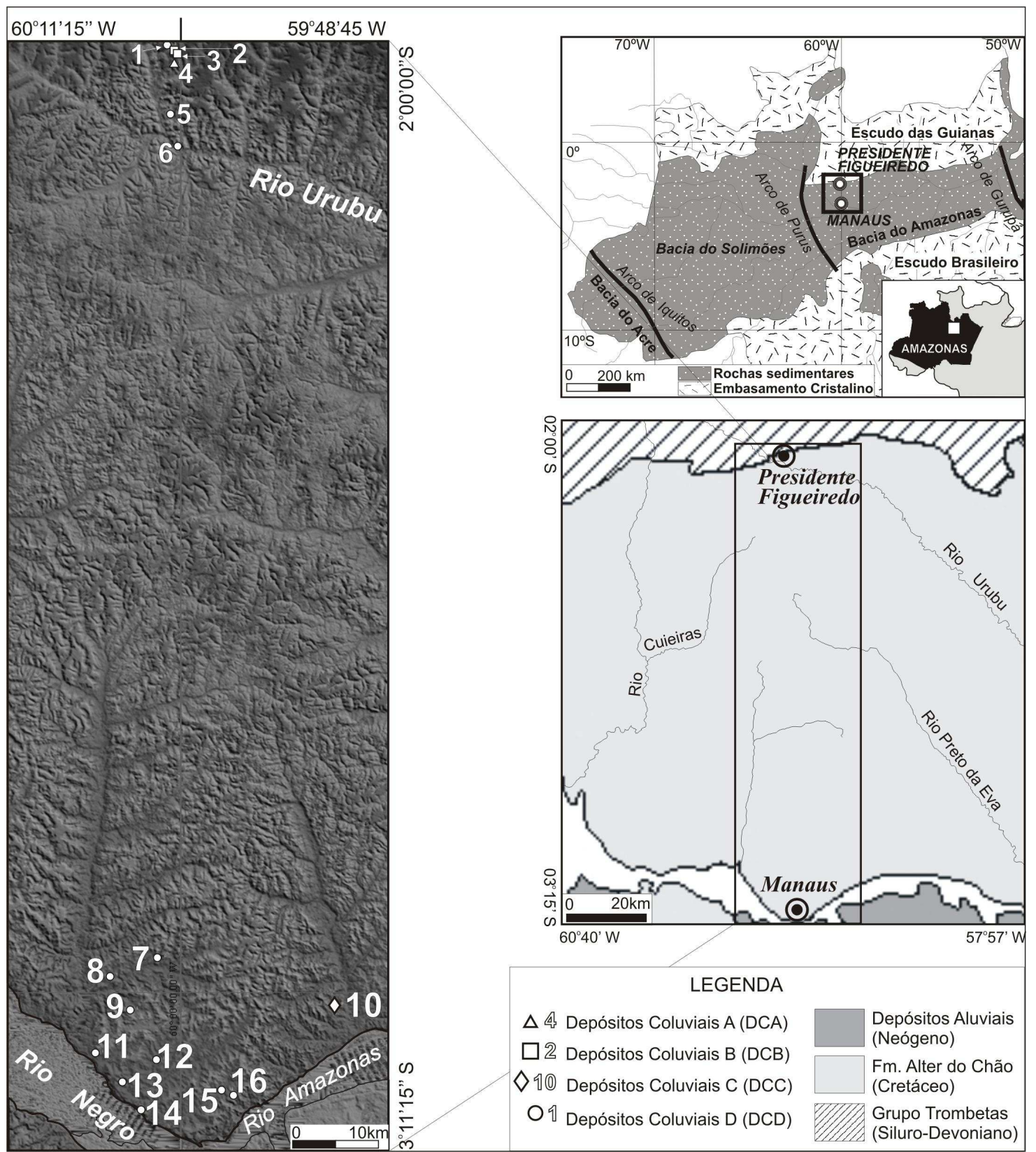

Figura 4.11: Situação da área de estudo, compreendida entre as cidades de Manaus e Presidente Figueiredo, nordeste do estado do Amazonas. As indicações numeradas ao longo da área representam os afloramentos dos depósitos coluviais estudados. 
Perfis lateríticos estão desenvolvidos indistintamente sobre todas as unidades da área estudada e, algumas vezes, podem ser utilizados como critério para diferenciá-las. Nas rochas do Paleozóico inferior, os perfis lateríticos apresentam horizontes ferruginosos com incipiente horizonte bauxítico e perfis com horizontes bauxíticos bem desenvolvidos, enquanto sobre as rochas cretáceas apresentam perfis com horizontes ferruginosos. Camadas argilosas intensamente caulinizadas e, às vezes, com aspecto semi-flint (argilas enriquecidas em sílica) ocorrem principalmente na sucessão superior da Formação Alter do Chão (Giral-Kacmarcik et al. 1998), também estão relacionadas aos eventos lateríticos. As unidades cenozóicas são geralmente limitadas por crostas ferruginosas, sem horizonte bauxítico, e comumente apresentam arenitos com cimentação por óxidos e hidróxidos de ferro (Rozo et al. 2005).

Os diferentes horizontes lateríticos evidenciam fases de intemperismo que afetaram a Amazônia desde o Paleógeno (Truckenbrodt \& Kotschoubey 1981, Costa 1991, Fernandes Filho et al. 1997, Horbe et al. 2001). A fase de lateritização mais antiga remonta do EocenoOligoceno até o Mioceno, enquanto que os perfis mais recentes formaram-se no PlioPleistoceno (Costa 1990, 1991, Horbe et al. 1997, 2001).

Todos os perfis lateríticos estão recobertos por oxissolos amarelos (Horbe et al. 2001), que contêm até $95 \%$ de caulinita e grãos dispersos de quartzo, denominados de Argila de Belterra (Sombroek 1966). Estes oxissolos têm sido considerados como produto do intemperismo de crostas ou solos retrabalhados e acumulados em vales (Truckenbrodt \& Kotschoubey 1981, Horbe et al. 2001).

Falhas normais e transcorrentes truncam os perfis lateríticos e solos e, algumas vezes, controlam a sedimentação recente e feições geomorfológicas, tais como desembocaduras afogadas, capturas fluviais, cachoeiras e feições pseudocársticas como relevos reliquiares e cavernas (Franzinelli \& Latrubesse 1993, Costa et al. 2001, Nogueira \& Sarges 2001, Franzinelli \& Igreja 2002). 


\section{MÉTODOS}

A caracterização dos depósitos coluvais envolveu análises estratigráficas e sedimentológicas de afloramentos em cortes de estradas (Fig. 4.1), incluindo o reconhecimento, levantamento e descrição das características faciológicas. A elaboração de seções panorâmicas de afloramentos auxiliou na definição dos elementos arquiteturais e geometria de fácies, seguindo as recomendações de Walker (1992) e Arnot et al. (1997). As descrições das fácies coluviais foram complementadas por análises granulométricas. Modelos de fácies para depósitos coluviais ainda são escassos na literatura e, dessa forma, buscou-se caracterizar as fácies adaptando-se a abordagem para depósitos aluviais proposta por Miall (1992). As cores dos sedimentos foram classificadas de acordo com a carta de cores "Munsell Rock Color Chart".

A correlação entre a disposição topográfica dos depósitos coluviais, as características faciológicas e as relações de contatos basais com as diferentes unidades da Bacia do Amazonas foram critérios auxiliares adotados na diferenciação dos depósitos coluviais da área. Na análise da distribuição espacial dos depósitos coluviais da região estudada, os locais de ocorrência dos afloramentos foram plotados nos Modelos Digitais de Elevação (MDE’s), produzidos pela missão SRTM (Shuttle Radar Topographic Mission) e disponibilizados pelo USGS (2003), na área inserida entre as coordenadas geográficas $2^{\circ} 00^{\prime} 00^{\prime \prime} \mathrm{S}$ e $60^{\circ} 19^{\prime} 12^{\prime \prime} \mathrm{W}$ a $3^{\circ} 11^{\prime} 15^{\prime \prime S}$ e $59^{\circ} 48^{\prime} 45^{\prime \prime} \mathrm{W}$ (Fig. 4.11).

\section{DEPÓSITOS COLUVIAIS}

Os depósitos coluviais da região foram individualizados em quatro tipos distintos de depósitos, denominados de DCA, DCB, DCC e DCD (Tab. 4.1), caracterizados por corpos sedimentares com geometria em cunha, que se adelgaçam nas porções mais distais, camadas 
com geometria irregular, lenticulares, tabulares e sub-horizontais, de larguras métricas. Enquanto na borda norte da Bacia do Amazonas estes depósitos distribuem-se sobre diversas unidades litoestratigráficas paleozóicas e cretáceas, na região de Manaus os depósitos coluviais ocorrem exclusivamente sobre as rochas cretáceas da Formação Alter do Chão (Fig. 4.11).

Os depósitos coluviais geralmente são recobertos por oxissolos argilo-arenosos ou areno-argilosos de coloração alaranjada-amarelada, com aspectos maciços, que podem ter origem sedimentar (Truckenbrodt \& Koutschoubey 1981). Estes solos se apresentam mais espessos na região de Presidente Figueiredo, onde alcançam até $2 \mathrm{~m}$ de espessura, enquanto na região de Manaus não ultrapassam 1m sobre os depósitos coluviais. Os oxissolos também recobrem indiscriminadamente todas as unidades litoestratigráficas da região.

\begin{tabular}{|c|c|c|c|c|}
\hline $\begin{array}{l}\text { Depósito } \\
\text { Coluvial } \\
\end{array}$ & Fácies & Processos & $\begin{array}{c}\text { Geometria do } \\
\text { Depósito }\end{array}$ & $\begin{array}{c}\text { Características da } \\
\text { Área-Fonte }\end{array}$ \\
\hline$D C A$ & $\begin{array}{l}\text { Cmsc - Cascalhos maciços, } \\
\text { sustentados por clastos. } \\
\text { Cmsm - Cascalhos maciços, } \\
\text { sustentados por matriz } \\
\mathbf{A m} \text { - Areias maciças }\end{array}$ & $\begin{array}{l}\text { Fluxos fluviais } \\
\text { semi-confinados; } \\
\text { Fluxo de detritos }\end{array}$ & $\begin{array}{l}\text { Camadas sub- } \\
\text { horizontais e em } \\
\text { cunha }\end{array}$ & $\begin{array}{l}\text { Platôs com perfis } \\
\text { lateríticos completos } \\
\text { desenvolvidos sobre as } \\
\text { formações Nhamundá, } \\
\text { Pitinga ou Manacapuru }\end{array}$ \\
\hline$D C B$ & $\begin{array}{l}\text { Cmsf - Cascalhos maciços } \\
\text { com seixos de lamitos semi- } \\
\text { flint }\end{array}$ & $\begin{array}{l}\text { Fluxo sub-aquoso } \\
\text { relacionado ao } \\
\text { escoamento } \\
\text { superficial; } \\
\text { Fluxo de detritos. }\end{array}$ & $\begin{array}{l}\text { Camadas } \\
\text { tabulares e sub- } \\
\text { horizontais }\end{array}$ & $\begin{array}{llr}\text { Fácies } & \text { lamíticas com } \\
\text { argila } & \text { semi-flint } & \text { da } \\
\text { Formação Alter do Chão }\end{array}$ \\
\hline$D C C$ & $\begin{array}{l}\text { Cmsm } \\
\text { Cgi - Cascalhos maciços com } \\
\text { gradação inversa }\end{array}$ & $\begin{array}{l}\text { Fluxo torrencial; } \\
\text { Fluxo de detritos }\end{array}$ & $\begin{array}{l}\text { Camadas } \\
\text { tabulares }\end{array}$ & $\begin{array}{lr}\text { Pretérito } & \text { depósito } \\
\text { coluvial } & \text { desenvolvido } \\
\text { sobre a Formação Alter } \\
\text { do Chão }\end{array}$ \\
\hline$D C D$ & $\begin{array}{l}\text { Cmsc } \\
\text { Cmsm } \\
\text { Cgi }\end{array}$ & $\begin{array}{l}\text { Fluxo torrencial; } \\
\text { Fluxo de detritos }\end{array}$ & $\begin{array}{l}\text { Camadas } \\
\text { lenticulares, em } \\
\text { cunha e sub- } \\
\text { horizontais }\end{array}$ & $\begin{array}{l}\text { Paleopavimento residual } \\
\text { sobreposto a platôs } \\
\text { desenvolvidos sobre as } \\
\text { formações Nhamundá, } \\
\text { Pitinga, Manacapuru e } \\
\text { Alter do Chão }\end{array}$ \\
\hline
\end{tabular}

Tabela 4.1: Fácies, processos sedimentares e aspectos morfológicos considerados em função do controle topográfico na distribuição dos depósitos coluviais da região entre Manaus e Presidente Figueiredo. 


\section{Depósito Coluvial A (DCA)}

O DCA, com até $2 \mathrm{~m}$ de espessura, apresenta-se em contato discordante erosivo sobre rochas sedimentares intemperizadas da Formação Pitinga, restrito à região de Presidente Figueiredo (Fig. 4.12). Estes depósitos se adelgaçam lateralmente sobre uma superfície levemente inclinada $\left(\sim 3^{\circ}\right)$ para NW. Compreendem camadas sub-horizontais constituídas por areias maciças (fácies Am), de coloração amarelada (cor 10 YR 6/6), com grânulos de quartzo angulosos, de baixa esfericidade e mal selecionados, e lentes de cascalhos com espessura em torno de 1m, com acamamento maciço, que ocorrem na porção intermediária da sucessão (fácies Cmsm). Os grãos, geralmente de crosta ferruginosa, muito angulosos, com baixa esfericidade, de tamanho seixo e matacão, envoltos por película ferruginosa de coloração amarela. $\mathrm{O}$ arcabouço aberto destas lentes de cascalho exibe matriz de coloração alaranjada (cor 10 YR 7/4). O topo da sucessão é marcado por cascalhos maciços (fácies Cmsc), com grânulos e seixos de lamitos (argilito/siltito), de cor arroxeada (cor 5 P 4/2). Os grãos são subarredondados, com baixa esfericidade, mal-selecionados, dispostos em arcabouço fechado, sustentados por clastos, com matriz arenosa amarelada (cor 10 YR 5/4).

\section{Depósito Coluvial B (DCB)}

O DCB tem ocorrência limitada à região de Presidente Figueiredo, recobrindo o topo de morros testemunhos com depósitos caulinizados da Formação Alter do Chão. Constitui camadas com geometria tabular a sub-horizontal e espessura média de 1,5m, que preenchem depressões inclinadas até $3^{\circ}$ para sul (Fig. 4.13). Os cascalhos formam camadas maciças e apresentam arcabouço aberto (fácies Cmsf), com matriz arenosa de coloração alaranjada (cor 10 YR 7/4). Os grãos de tamanho seixo variam de $1 \mathrm{~cm}$ a $4 \mathrm{~cm}$, são mal-selecionados, subangulosos, com baixa esfericidade, de composição de argilito semi-flint com coloração 
acinzentada (cor N8). Subordinadamente, ocorrem seixos com tamanho de até $1 \mathrm{~cm}$ e grânulos ferruginizados, com núcleo quartzoso envolvido por matriz argilosa ferruginizada avermelhada (cor $10 \mathrm{R}$ 2/2), com superfície constituída por película de cor castanhoamarelado.
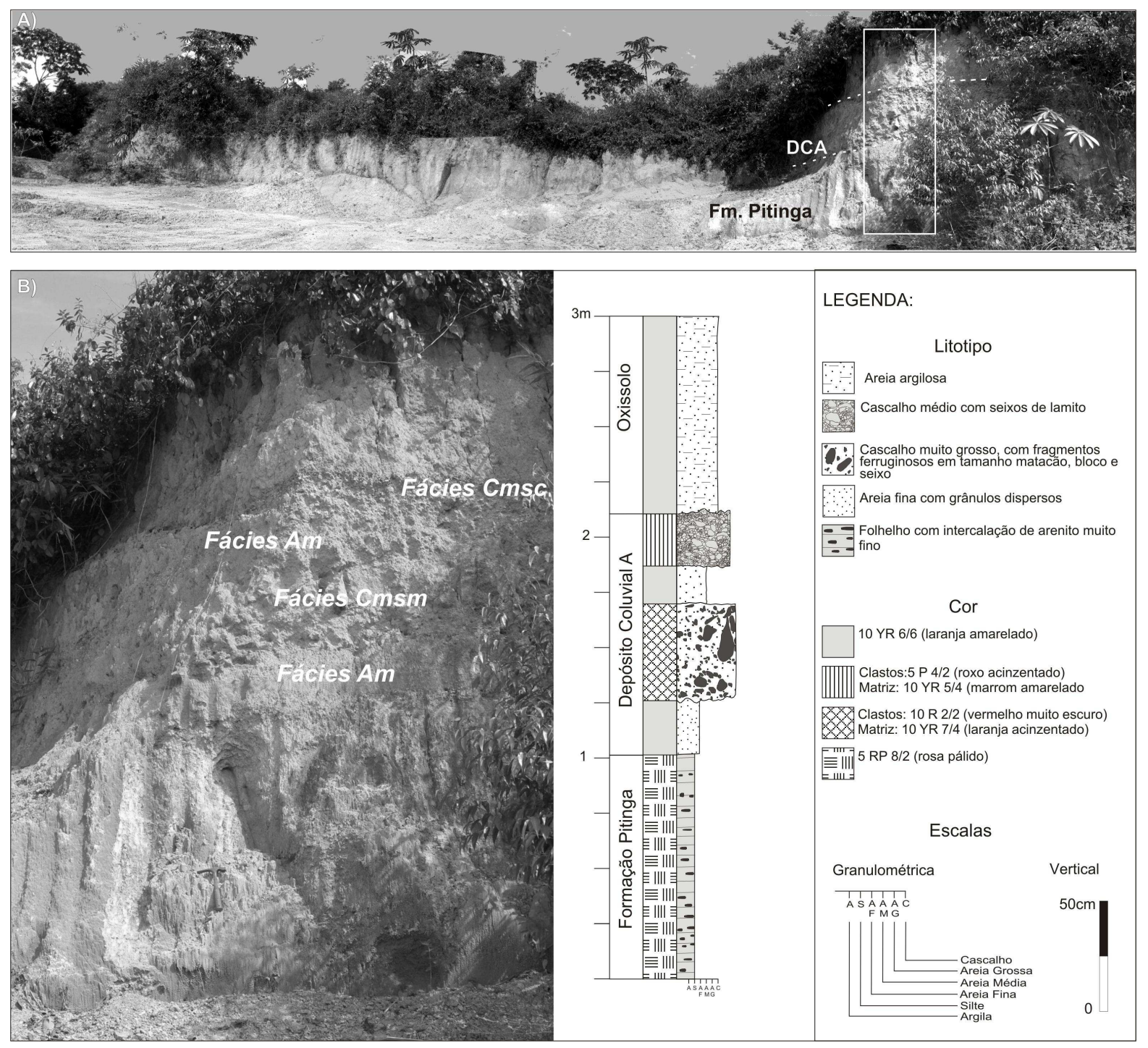

Figura 4.12: Exemplo da sucessão sedimentar característica do DCA. A) Seção panorâmica do afloramento P4, localizado na rodovia BR-174 (km 108). B) Observar a geometria lenticular e a alternância de camadas de cascalhos sustentados por matriz, cascalhos sustentados por clastos, com intercalações de camadas de areias, resultantes de fluxos de detritos associados a fluxos torrenciais semi-confinados. 

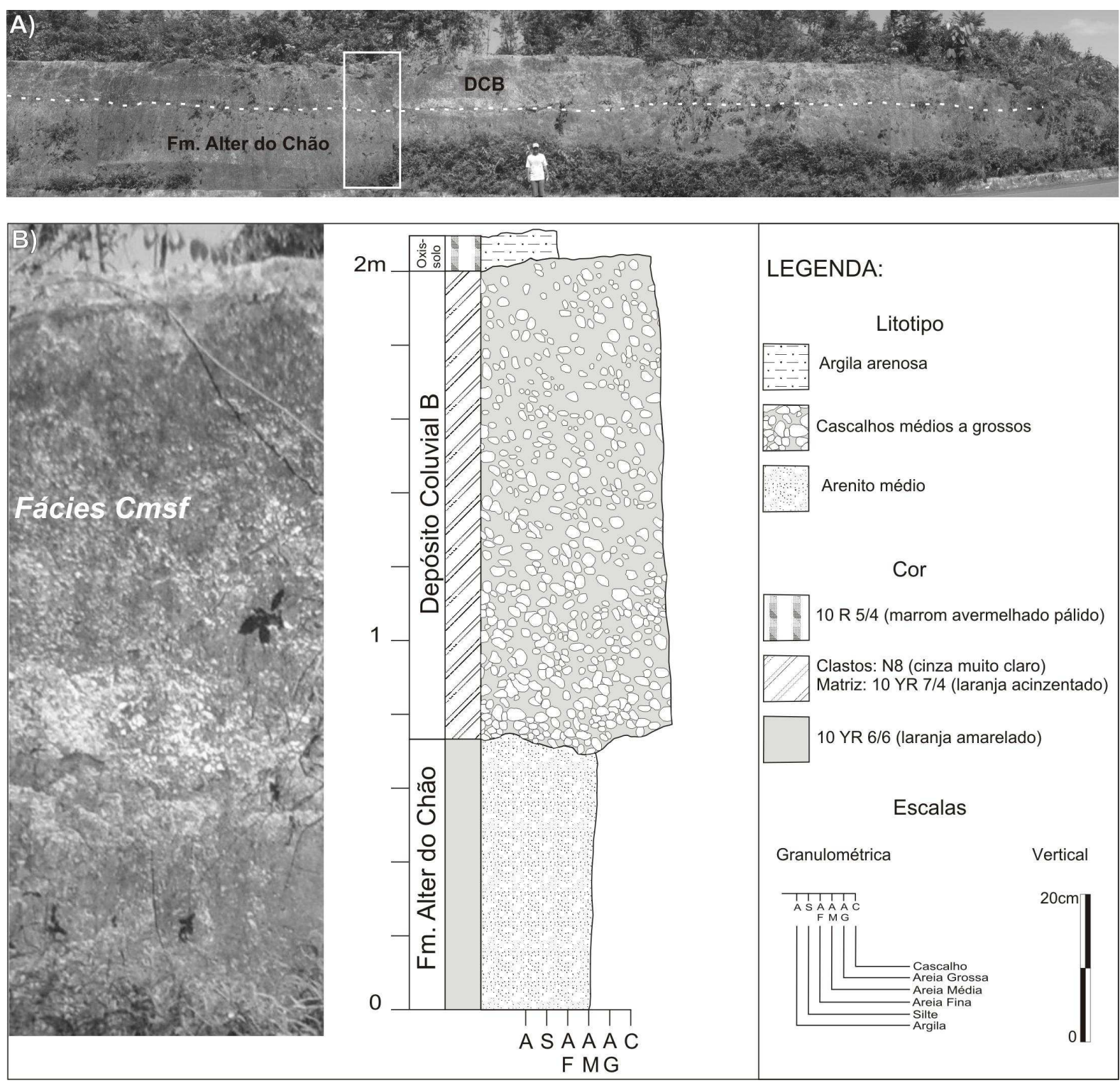

Figura 4.13: Aspectos sedimentológicos e estratigráficos do DCB. A) Seção panorâmica do afloramento P3, localizado na rodovia BR-174 (km 110,5), mostrando a geometria subhorizontal do depósito. B) O perfil estratigráfico exibe os detalhes da sucessão sedimentar, constituída por espesso pacote de cascalhos; concentrados na base.

\section{Depósito Coluvial C (DCC)}

O DCC está desenvolvido em platôs baixos (interflúvios alongados com baixa altimetria) e compreende espessa camada basal de cascalhos finos, sustentados por matriz argilosa de coloração alaranjada (cor 10 YR 7/4), com arcabouço aberto, mal-selecionados, subarredondados, com alta esfericidade, apresentando gradação inversa (fácies Cfgi). 
Apresenta inclinação em torno de $8^{\circ}$ para leste e espessamento das camadas na porção central (Fig. 4.14). Consistem de seixos de até $3 \mathrm{~cm}$ de diâmetro, com composição predominante de lamitos acinzentados (cor 5 Y 8/1), e subordinados grânulos de quartzos. O topo da sucessão é constituído por cascalhos maciços, mal-selecionados, subarredondados, com alta esfericidade, sustentados por matriz argilosa de coloração alaranjada clara (cor 10 YR 7/4). Os grãos consistem de seixos, blocos e matacões de lamitos de coloração branco-acinzentado (cor N8), apresentando película em tons variegados. Podem ocorrer esparsos grânulos e seixos de quartzo com tamanho de até $0,8 \mathrm{~cm}$ de diâmetro.

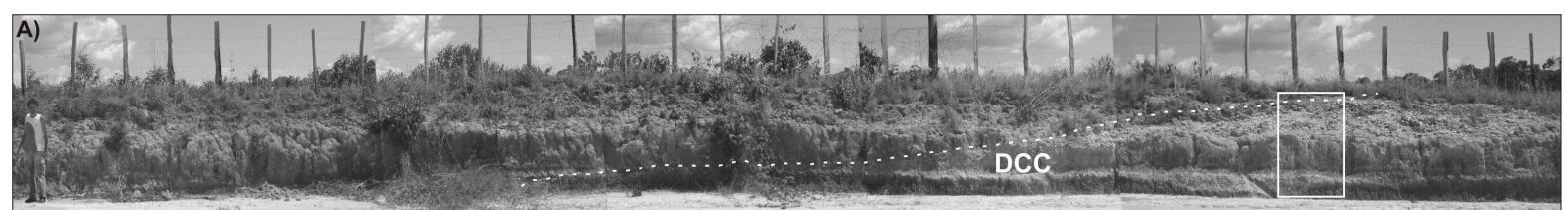

Fm. Alter do Chão

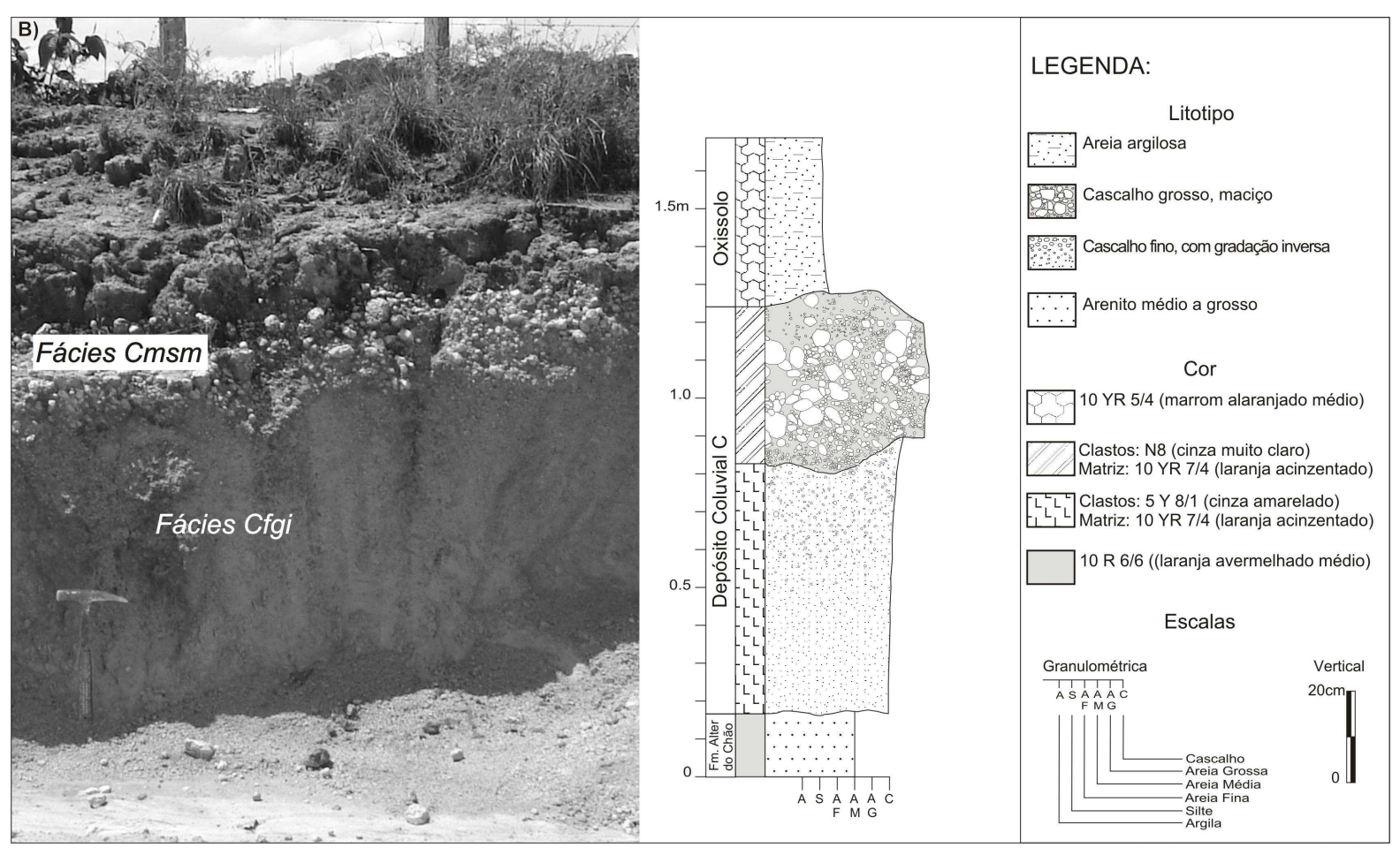

Figura 4.14: Sucessão sedimentar característica do DCC. A) Exposição em interflúvio de baixa altitude, exemplificado pelo afloramento P10, localizado no Ramal do Brasileirinho, zona leste de Manaus. B) Perfil estratigráfico mostrando detalhes da sucessão sedimentar. As camadas possuem geometria tabular, com inclinação de $8^{\circ}$ para leste, e são caracterizadas pela associação de fácies Cmsm e Cfgi. 


\section{Depósito Coluvial D (DCD)}

Os depósitos tipo DCD têm ampla ocorrência na área de estudo, sobrepostos às formações Nhamundá, Manacapuru, Pitinga e Alter do Chão, compreendendo camadas com geometria em cunha a sub-horizontal, com inclinação em torno de $3^{\circ}$ e espessura bastante variada, desde $0,4 \mathrm{~m}$ até $1,5 \mathrm{~cm}$, aproximadamente (Fig. 4.15). Consistem em camadas de cascalhos maciços, com grãos em tamanhos polimoidais (fácies Cmsc e Cmsm) e cascalhos com gradação inversa, maciços, mal-selecionados, angulosos a subangulosos, com baixa esfericidade, com matriz argilosa de coloração amarelada a avermelhada. Mostram grande diversidade na composição dos grãos, apresentando camadas com três associações litológicas distintas. Foram descritos depósitos constituídos por camada contendo matacões, blocos e seixos de crostas ferruginosas ou seixos lateríticos e seixos quartzosos, com grânulos de quartzo e ferruginosos associados, que podem se apresentar envoltos por películas ferruginosas. Também foram descritos depósitos compostos por camada com seixos oblatos e angulosos de arenito fino ferruginizado, seixos ferruginosos angulosos, seixos arredondados e com alta esfericidade de arenito, ou seixos e grânulos de quartzo. Ocorrem, ainda, depósitos constituídos por camada com seixos ferruginosos angulosos e com baixa esfericidade, grânulos de quartzo e subordinados grânulos de argila semi-flint branco-acinzentada. 

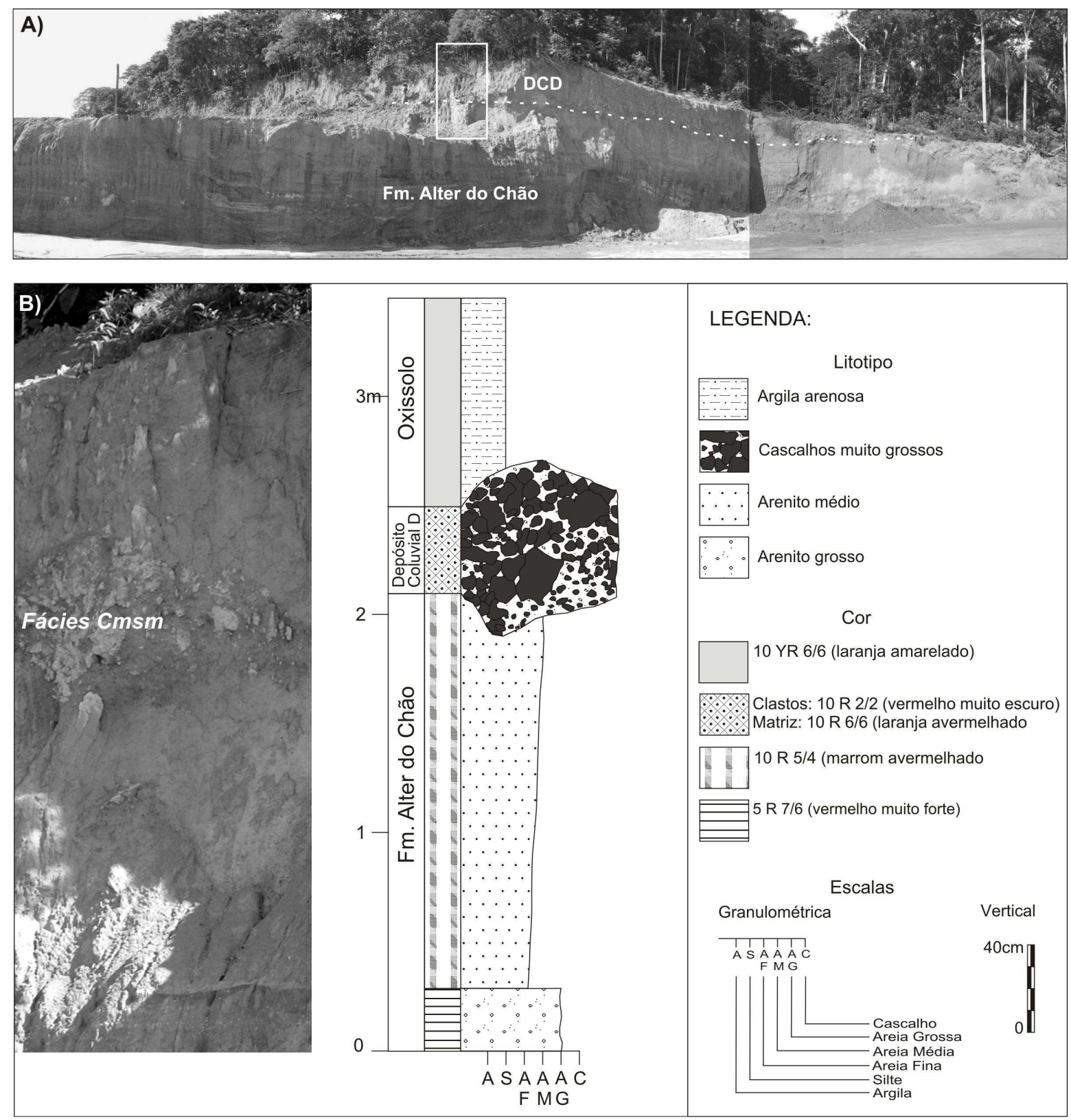

Figura 4.15: Exposição representativa dos depósitos DCD. A) Seção panorâmica do afloramento P11, localizado na avenida do Turismo, nas adjacências do rio Negro zona sudoeste de Manaus. Destaca-se a geometria sub-horizontal do depósito. B) No perfil estratigráfico destaca-se o caráter maciço e granulação polimoidal dos cascalhos que constituem a sucessão sedimentar do DCD. 


\section{PROCESSOS DEPOSICIONAIS}

Os depósitos de cascalhos com seixos, blocos e matacões, exibem predominantemente camadas maciças com arcabouço aberto (fácies Cmsm e Cmsf), camadas maciças com arcabouço fechado (facies Cmsc), acamamento com gradação inversa (Cgi) e camadas de areias maciças (Am). Os sedimentos foram depositados sob ação combinada de processos gravitacionais, principalmente fluxo de detritos, e fluxos sub-aquosos de alta energia (fluxos torrenciais e enxurradas). As fácies Cmsm, Am e Cmsf indicam fluxo de detrito viscoso, enquanto a fácies Cmsc, com arcabouço fechado, sugere fluxo menos viscoso. A presença de gradação inversa (fácies Cgi) nos sedimentos conglomeráticos destes depósitos implica em fluxo de alta energia, originado por escoamento superficial difuso e torrencial em direção às vertentes, possivelmente a partir de chuvas torrenciais ou enxurradas; na deposição destes sedimentos, os mais finos concentram-se na base e as frações mais grossas ficam dispostas no topo, resultando na inversão textural dos sedimentos.

Estes processos de deposição atuaram sobre rochas intemperizadas e lateritizadas, com alta taxa de movimentação dos detritos, provavelmente em vários pulsos de coluviação. A característica textural dos sedimentos coluviais na região estudada, a natureza mal selecionada e a composição por seixos, blocos e matacões dispostos aleatoriamente indicam que o fluxo possuía alta viscosidade. Cutículas sobre os clastos evidenciam a exposição e cimentação por óxidos e hidróxidos de ferro, sugestivo de deposição subaérea. A imaturidade textural também reflete o curto transporte e implica em deposição de sedimentos relativamente próximos à área-fonte. $\mathrm{O}$ suprimento sedimentar foi proveniente de diferentes platôs desenvolvidos sobre perfis lateríticos aluminosos-ferruginosos e ferruginosos, cuja distribuição geográfica tem relação direta com os diferentes graus de maturidade geoquímica destes perfis, níveis intemperizados da Formação Alter do Chão e pretéritas acumulações residuais, como paleopavimentos, e talvez até depósitos coluviais mais antigos. Paleopavimentos formados 
por cascalhos residuais têm diversas origens e podem resultar da eliminação do material mais fino durante a exposição (Nye 1954, Ruhe 1959, Bigarella \& Mousinho 1965, Aleva 1989, Johnson 1990). As unidades paleozóicas lamíticas (formações Pitinga e Manacapuru), intemperizadas e ferruginizadas, forneceram clastos tabulares para osDCA, enquanto a fração arenosa pode ser oriunda da alteração e remoção dos depósitos da Formação Nhamundá. As fontes dos fragmentos de crostas foram os perfis lateríticos maturos (aluminososferruginosos), encontrados no DCA, que ocorrem nas proximidades da borda norte da Bacia do Amazonas, e os perfis lateríticos imaturos (ferruginosos), presentes nos DCC e DCD, distribuídos nas proximidades do rio Amazonas, conforme Horbe et al. (2001). Fácies argilosas silicificadas (lamitos tipo semi-flint) da Formação Alter do Chão serviram como fonte para o DCB.

Os oxissolos que recobrem indiscriminadamente os depósitos coluviais são de difícil interpretação, por não apresentarem estruturas diagnósticas de processos sedimentares, somente superfícies que atestam escorregamento atual. As sucessões mais espessas destes oxissolos podem significar possíveis depósitos coluviais pedogenizados, e a sua ocorrência diretamente sobre os depósitos coluviais estudados, interpretados como produto de fluxos gravitacionais, reforça esta interpretação, coadunando com a proposta de Truckenbrodt \& Koutschoubey (1981). Embora grande parte destes oxissolos sejam interpretados como produtos oriundos do intemperismo de crosta laterítica (Costa 1990, 1991), a sua remobilização por processos de denudação do relevo, já citados por Horbe et al. (2001), parece ser mais provável e ocorreu em tempos muito recentes. 


\section{GÊNESE DOS DEPÓSITOS COLUVIAIS}

A gênese dos depósitos coluviais estudados na região está associada à atuação de movimentos de massa que ocorreram sobre as rochas sedimentares da borda norte da Bacia do Amazonas desde o Neógeno, subordinada a uma relação entre o tipo de platô (interflúvio tabular de topos plano amplo ou alongado), rocha-mãe e a altimetria (Fig. 4.16). As forças gravitacionais, que impeliram o transporte e deposição de detritos provenientes das áreasfontes intemperizadas, podem ter sido ativadas por mecanismos erosivos, relacionados à incisão de canais, ou por movimentações neotectônicas, sendo que tais fatores podem ter atuado isolados ou combinados.

A incisão é o processo de aprofundamento de canal pelo rebaixamento progressivo do nível de base local (Collinson 1996), que ocorre quando o aporte sedimentar é menor que a taxa de remoção (Tynney 1962), ou quando o nível de base é rebaixado por uma quebra abrupta no perfil de equilíbrio do canal (Schumm 1999). Este mecanismo está associado à evolução e rejuvenescimento da rede de drenagem, e promove a expansão de uma bacia de drenagem, com a formação de novos canais de primeira ordem (Simon et al. 1999). O rejuvenescimento de drenagem envolve tanto o processo de erosão, nas porções à montante, quanto de deposição de sedimentos, à jusante. A erosão, que ocorre nas cabeceiras, ravinas e voçorocas, é controlada por forças gravitacionais, com atuação predominante de processos de queda de detritos e deslizamentos, ambos ocorrendo em eventos episódicos, o que caracterizaria no registro geológico pulsos de sedimentação, e explicaria a ocorrência de vários eventos de sedimentação coluvial, assim como a distribuição fragmentada destes depósitos. 


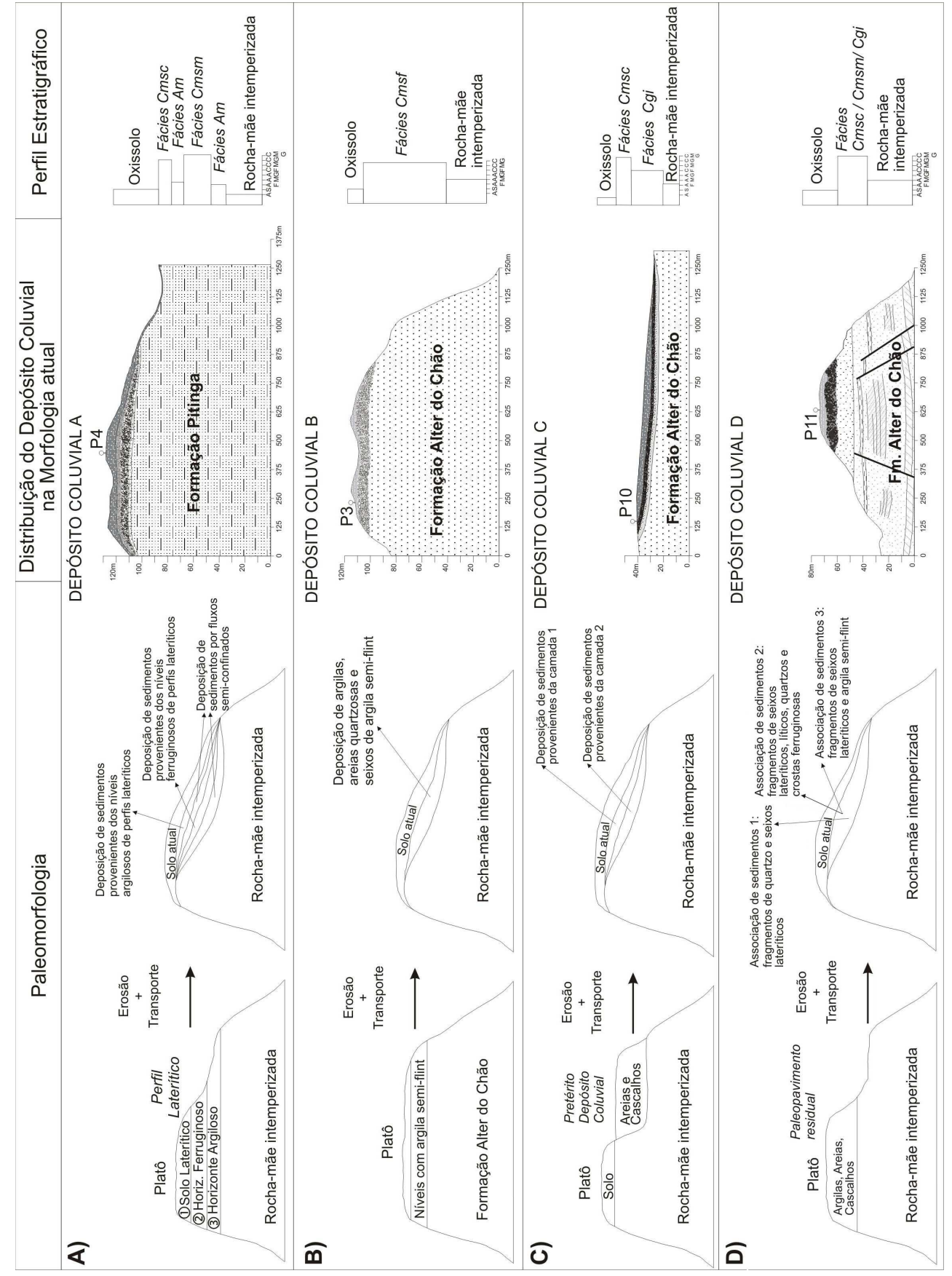

造 。

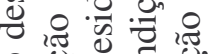

ส․

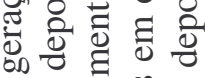

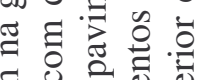

है

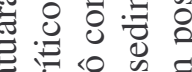

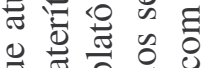

을 흔 웅

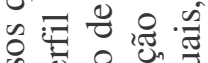

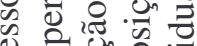

¿

히웜

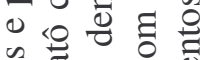

율

巳ั

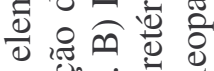

造的䒕

릴 है

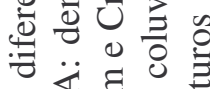

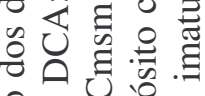

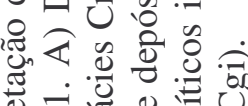

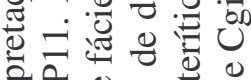

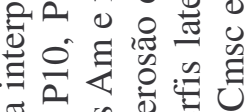

छิ

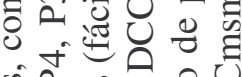

की

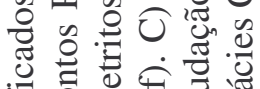

过它氞

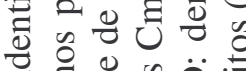

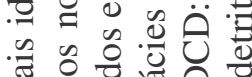

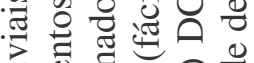

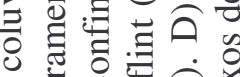

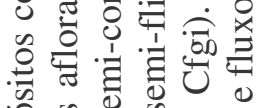

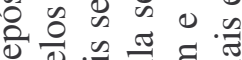

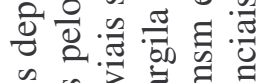

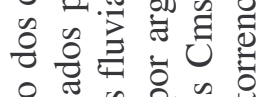

$\gg$.

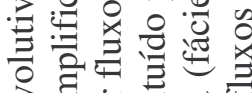

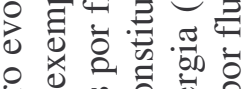

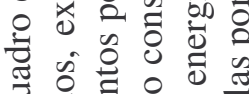

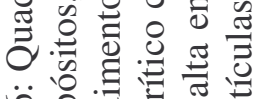

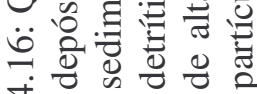

苛 
Tricart (1977) sugeriu que durante o Holoceno atuou uma intensa dissecação na Amazônia, ocasionada pelo rebaixamento do nível de base local, por sua vez influenciado pela regressão pré-flanderiana. Uma regressão anterior, que foi responsável por abrupto abaixamento do nível do mar no Mioceno (Shimabukuro \& Arai 1999), ao qual está associado uma discordâcia regional denominada de Discordância Tortoniana, que foi produzida pela maior queda eustática do Neógeno (Arai 2005). Este evento pode ter promovido o rebaixamento do nível da base da região, ocasionando variações paleo-hidrológicas e favorecendo o período de intensa dissecação da região. Contudo, não temos evidências para relacionar a geração do depósito mais antigo estudado (o DCA) a este grande período erosivo da região.

Os movimentos tectônicos atuaram ao longo do Cenozóico na região, podem apresentar correlação com os eventos de aplainamentos neógenos (Tricart 1977). Desta forma, considera-se que as flutuações paleoclimáticas, influenciadas por eventos transgressivos e regressivos de caráter mundial, foram fatores decisivos, associados aos movimentos tectônicos cenozóicos, foram os fatores decisivos na construção do modelado da região, impulsionando os eventos de denudação que ativaram a formação dos depósitos coluviais.

As movimentações neotectônicas são eventos registrados e confirmados em diversos estudos na região (Sternberg 1950, Wanderley Filho 1991, Fernandes Filho et al. 1997, Costa et al. 2001, Nogueira \& Sarges 2001, Franzinelli \& Igreja 2002, Latrubesse \& Franzinelli 2002). Possivelmente, o marco mais importante de atividades tectônicas cenozóicas na região amazônica seja a inversão de drenagem da paleobacia hidrográfica do Amazonas, que ocorreu no Neomioceno (Mapes et al. 2006), como resposta ao contínuo processo de soerguimento dos Andes (Hoorn et al. 1995).

Estas movimentações neotectônicas na área podem ter favorecido o colapso de rochas e perfis lateríticos maturos e imaturos, promovendo a formação de detritos que constituíram o 
suprimento sedimentar na deposição de unidades coluviais da região. Provavelmente as vertentes preenchidas pelos sedimentos coluviais poderiam estar encaixadas em falhas geradas por eventos tectônicos, que contribuíram na criação de espaço de acomodação para o suprimento sedimentar gerado pelos processos denudacionais recentes da região.

\section{POSIÇÃO LITOESTRATIGRÁFICA E CORRELAÇÃO COM AS SUPERFÍCIES GEOMORFOLÓGICAS DA AMAZÔNIA}

A deposição dos sedimentos coluviais foi posterior às fases de lateritização ocorridas na Amazônia, pois é freqüente a ocorrência de fragmentos de crosta laterítica nestes depósitos, provenientes da progressiva degradação dos diferentes horizontes que constituem os perfis lateríticos desenvolvidos sobre as rochas da região. Os depósitos coluviais analisados ocorrem em contato discordante erosivo sobre unidades sedimentares paleozóicas, mesozóicas e cenozóicas pertencentes à Bacia do Amazonas. Os depósitos coluviais recobrem indiscriminadamente diferentes superfícies de aplainamento que formam platôs sustentados por perfis lateríticos maturos e imaturos ( $c f$. Horbe et al. 2001).

A recorrência dos processos de lateritização na Amazônia, com várias fases de lateritização desde o Paleógeno (Koutschoubey \& Truckenbrodt 1981, Costa 1991, Horbe et al. 2001), levou à formação de perfis lateríticos diferenciados em sua composição geoquímica. Os perfis lateríticos aluminosos-ferruginosos foram os primeiros a se formar, considerando-se que para a formação de bauxita as rochas necessitam de longa exposição ao processo de lateritização (Costa 1991, Horbe et al. 2001), enquanto que os perfis lateríticos ferruginosos são mais recente, por suas características geoquímicas (Horbe et al. 2001).

As superfícies de aplainamento relacionadas aos ciclos de denudação no Suriname, definidos por King (1964), foram associadas aos eventos globais de lateritização e estendidas para a região Amazônica por Choubert (1957), para a Guiana Francesa por Pollack (1983), 
para o Suriname por Aleva (1984) e Bardossy \& Aleva (1990), e também para a Amazônia oriental por Kotschoubey \& Truckenbrodt (1981).

A Superfície Gondwana (King 1956), encontrada principalmente na Venezuela e Roraima (Brasil), representa o nível topograficamente mais alto, com elevações acima de 1000m, considerada do Cretáceo ou de idade mais antiga. A Superfície Sul-Americana, ou “Nível bauxítico principal”, é considerada do Cretáceo Superior a Paleógeno. A Superfície Velhas Inferior, relacionada aos perfis lateríticos ferruginosos com incipientes horizontes bauxíticos, é atribuída ao Oligoceno-Mioceno inicial.

A Superfície Velhas Superior é associada aos perfis lateríticos ferruginosos, porém com alto conteúdo de sílica (imaturos), e de idade atribuída ao Mioceno. Entretanto, datações destas superfícies possibilitariam uma correlação mais apropriada aos depósitos coluviais, bem como definiria precisamente as suas posições geomorfológicas e as idades de formação dos depósitos de bauxita da Amazônia.

Trindade et al. (2006), a partir de dados paleomagnéticos das crostas lateríticas, verificaram que as crostas aluminosas e ferruginosas desenvolvidas nos perfis lateríticos ferruginosos-aluminosos da Formação Nhamundá apresentam orientações dos pólos magnéticos de 50-70 Ma (Maastrichiniano-Ypresiano), enquanto que as crostas ferruginosas desenvolvidas sobre a Formação Alter do Chão e subordinadamente sobre a Formação Nhamundá, apresentam orientação dos pólos recentes de 5-24 Ma, no Chattiano a Zancleano. Estas idades corroboram aproximadamente com as idades das superfícies geomorfológicas para a Amazônia. A partir da correlação destes dados com as superfícies geomorfológicas, a idade do DCA pode ser atribuída ao Plio-Pleistoceno, enquanto os demais colúvios podem ter iniciado a sua deposição no Pleistoceno tardio (Fig. 4.17). 


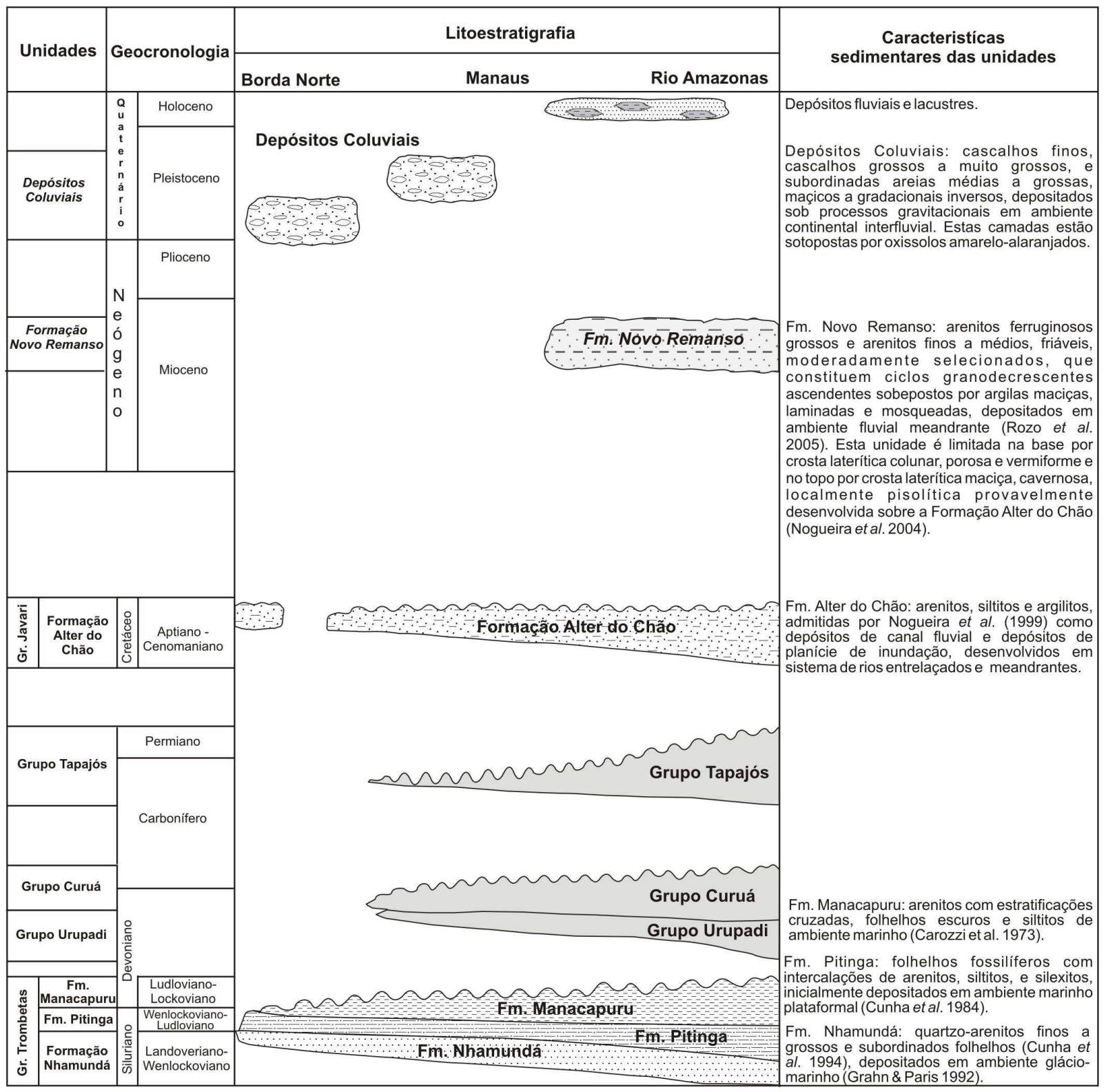

Figura 4.17: Coluna estratigráfica proposta para a região de Manaus e Presidente Figueiredo. As sucessões sedimentares em cinza correspondem às unidades estratigráficas não aflorantes na área. 


\section{CONCLUSÕES}

Os depósitos coluviais da região de Manaus-Presidente Figueiredo são representados por cascalhos e areias que abrangem as fácies Cmsc (cascalhos maciços sustentados por clastos), Cmsm (cascalhos maciços sustentados por matriz), Cmsf (cascalhos maciços com lamitos semi-flint), Cfi (cascalhos com gradação inversa) e Am (areias maciças), depositados em ambiente continental sob condição de alta energia. Caracterizam exposições com até $2 \mathrm{~m}$ de espessura, lateralmente descontínuas, e estão distribuídos nas vertentes, associadas às cabeceiras de drenagens, em cotas desde 30m (Manaus) até 250m (Presidente Figueiredo). O caráter fragmentado da distribuição destes depósitos impossibilita seu mapeamento em escalas menores do que 1:10.000. Os colúvios mais antigos foram depositados no Neógeno tardio, enquanto os demais colúvios podem ter iniciado a sua deposição no Pleistoceno, possivelmente estendendo-se ao Holoceno.

A sedimentação destes depósitos foi resultante da ação de fluxos não canalizados. A fácies Cmsm, de arcabouço aberto, indica fluxos de detritos viscosos, enquanto a fácies Cmsc, com arcabouço fechado, sugere fluxo menos viscoso. A composição textural dos sedimentos coluviais na região estudada, com presença de grãos com tamanhos polimodais, mal selecionados, angulosos a subangulosos, indica fluxos de pequena duração, com curto transporte e elevada taxa de sedimentos. A proveniência dos sedimentos foi originada da desagregação e remoção de sedimentos associados a perfis lateríticos maturos e perfis imaturos, fácies argilosas da Formação Alter do Chão, paleopavimentos residuais ou possivelmente depósitos coluviais pretéritos desenvolvidos sobre encostas associadas aos interflúvios tabulares (platôs). 
A formação dos depósitos coluviais é atribuída à incisão de canais, num processo de rejuvenescimento de drenagem ativado por movimentos neotectônicos. Estas incisões induziram o colapso de rochas e perfis lateríticos e impulsionaram os processos gravitacionais, favorecendo a formação de depósitos coluviais da região. A geração do espaço de acomodação na deposição dos depósitos coluviais mais antigos (DCA) foi influenciada por atividade tectônica; em contraste, a deposição dos colúvios mais jovens (DCD) ocorreu provavelmente após a última fase de movimentação neotectônica.

A evolução da paisagem está relacionada aos processos geomorfogenéticos atuantes sobre as rochas sedimentares da borda norte da Bacia do Amazonas, possivelmente desde o início do Paleógeno, após a formação dos perfis lateríticos maturos. As áreas de deposição estavam associadas a antigas cabeceiras de drenagens, que hoje configuram bordas de interflúvios tabulares dissecados (platôs).

\section{Agradecimentos}

À FAPESP pelo suporte financeiro neste trabalho (Processo 02/09564-0) e pela concessão de bolsa DR a Roseane Sarges, e a UFAM, pelo apoio logístico e infra-estrutura disponibilizada nos levantamentos de campo. Ao Prof. Dr. Claudio Limeira Mello pela leitura crítica e sugestões ao texto e ao Dr. Jason Kirk, pela revisão do abstract. 


\title{
5. CARACTERIZAÇÃO DO RELEVO DA REGIÃO DE MANAUS, AMAZÔNIA CENTRAL
}

Submetido à Revista Brasileira de Geomorfologia

\begin{abstract}
Roseane Ribeiro Sarges ${ }^{1}$, Telma Mendes da Silva ${ }^{2}$, Claudio Riccomini ${ }^{3}$
1 Programa de Pós-graduação em Geoquímica e Geotectônica, Instituto de Geociências, Universidade de São Paulo, Rua do Lago, 562, 05508-080, São Paulo, Brasil. rrsarges@usp.br;

2 Departamento de Geografia, Instituto de Geociências, Universidade Federal do Rio de Janeiro, Ilha do Fundão, 21940-590, Rio de Janeiro, Brasil.telmendes@globo.com;

${ }^{3}$ Departamento de Geologia Sedimentar e Ambiental, Instituto de Geociências, Universidade de São Paulo, Rua do Lago, 562, 05508-080, São Paulo, Brasil. riccomin@usp.br; bolsista de produtividade em pesquisa do CNPq.
\end{abstract}

\section{RESUMO}

A caracterização do relevo da região de Manaus, nordeste do estado do Amazonas, foi fundamentada na análise da distribuição das feições geomórficas, definição dos compartimentos do relevo da área e identificação de elementos morfoestruturais do relevo. O modelado da região foi condicionado por movimentos tectônicos, que promoveram duas significativas reorganizações da rede de drenagem: a primeira, resultante da inversão do fluxo do rio Amazonas e uma segunda, que foi responsável pela captura e alteração do fluxo de canais de drenagem do interflúvio rio Negro - rio Branquinho, ocasionando a formação de um novo compartimento topográfico $(\Delta \mathrm{h}=75 \mathrm{~m})$. Os processos geomorfogenéticos propiciaram o aplainamento dos topos dos interflúvios em um estágio inicial, ação erosiva que levou a formação das superfícies geomorfológicas S1 e S2, mais antigas e associadas aos eventos de lateritização da área, e atualmente conduz a pediplanação da área, correlacionada à geração da superfície S3.

Palavras-chave: Relevo, geomorfometria, evolução da paisagem, Amazônia. 


\section{ABSTRACT}

The relief characterization of the Manaus region, in northeastern of the state of Amazonas, was based on the analysis of the distribution of the geomorphic features, definition of the topographics domains and identification of the morphostructural elements of the landscape. The shaping the landscape was controlled by two tectonic events, each of which caused significant reorganization of the existing drainage network. The first event resulted from the inversion of the flow direction of Amazonas river, whereas the second was responsible for the capture and flow alteration of the drainage channels of the Negro Branquinho divides, causing the formation of a new topographical domains $(\Delta \mathrm{h}=75 \mathrm{~m})$. The geomorphogenetic processes propitiated the leveling of the tops of the watershed in the initial stage. This erosional action lead initially to the formation of the old geomorphological surfaces S1 and S2, associated with lateritization events, and to present day pediplanation of the region (correlated with S3 surface).

Keywords: Relief, geomorphometry, landscape evolution, Amazonia.

\section{INTRODUÇÃO}

A Amazônia passou por profundas alterações na paisagem durante o Cenozóico, causadas por variações climáticas, paleo-hidrológicas e atividades tectônicas. Os soerguimentos e abatimentos de vários segmentos da Amazônia e ocasionaram rearranjos na rede de drenagem (Sternberg 1950, Cunha 1990, Hoorn et al. 1995, Costa et al. 2001, Horbe et al. 2001, Costa 2002, Bezerra 2003, Mapes et al. 2006, Almeida-Filho \& Miranda 2007). A interação entre estas variáveis foi responsável pela ativação dos processos geomorfogenéticos, atuantes desde o Paleógeno (Tricart 1977, Meis 1971, Franzinelli \& Igreja 2002). Neste trabalho, busca-se a avaliação destes efeitos na paisagem, a partir da quantificação de 
elementos geomórficos, utilizando os modelos digitais de elevação (DEM’s) disponibilizados pelo USGS (2003), que traz importantes informações sobre as características de relevo desta região.

A quantificação de elementos do relevo, técnica utilizada desde meados do século passado (Horton 1932, Strahler 1952, Howard 1967), vem sendo aplicada em estudos neotectônicos e de compartimentação de relevo (Meis et al. 1982, Golts \& Rosenthal 1993, Jianjun et al. 1997, Hiruma \& Riccomini 1999). No entanto, a resposta dada pelos estudos morfométricos pode ir além da delimitação e quantificação de feições geomorfológicas, auxiliando na interpretação e subsidiando a compreensão dos eventos geomorfológicos que afetaram uma dada região. Desta forma, o presente estudo busca investigar as características do relevo, bem como interpretar os processos erosivos e tectônicos envolvidos na elaboração da paisagem da região de Manaus.

\section{ÁREA DE ESTUDO}

A singular paisagem da porção nordeste do estado do Amazonas é caracterizada por conjuntos topográficos desenvolvidos sobre rochas siliciclásticas da Bacia do Amazonas, isolados pelos rios Negro, Uatumã e Jatapu (Fig. 5.1A e B). O conjunto topográfico I, onde está inserida a área de estudo (Figs. 5.1A, B e C), apresenta relevo tabuliforme constituído por interflúvios tabulares com diferentes graus de dissecação.

O conjunto topográfico I foi modelado sobre rochas da borda norte da Bacia do Amazonas (Fig. 5.1C). Na porção setentrional deste conjunto, ocorrem arenitos, folhelhos e siltitos pertencentes ao Grupo Trombetas, depositados em ambiente marinho a gláciomarinhos no intervalo Siluro-devoniano (Cunha et al. 1994). Os limites na porção sul é estabelecido pelos arenitos, siltitos e argilitos fluviais a flúvio-lacustres cretáceos (Caputo et 
al. 1972, Cunha et al. 1994, Nogueira et al. 1999), pertencentes à Formação Alter do Chão, unidade predominante da área, arenitos ferruginosos da Formação Novo Remanso (Rozo et al. 2005) e sedimentos flúvio-lacustres quaternários (Latrubesse \& Franzinelli 2002, Nogueira et al. 2006).

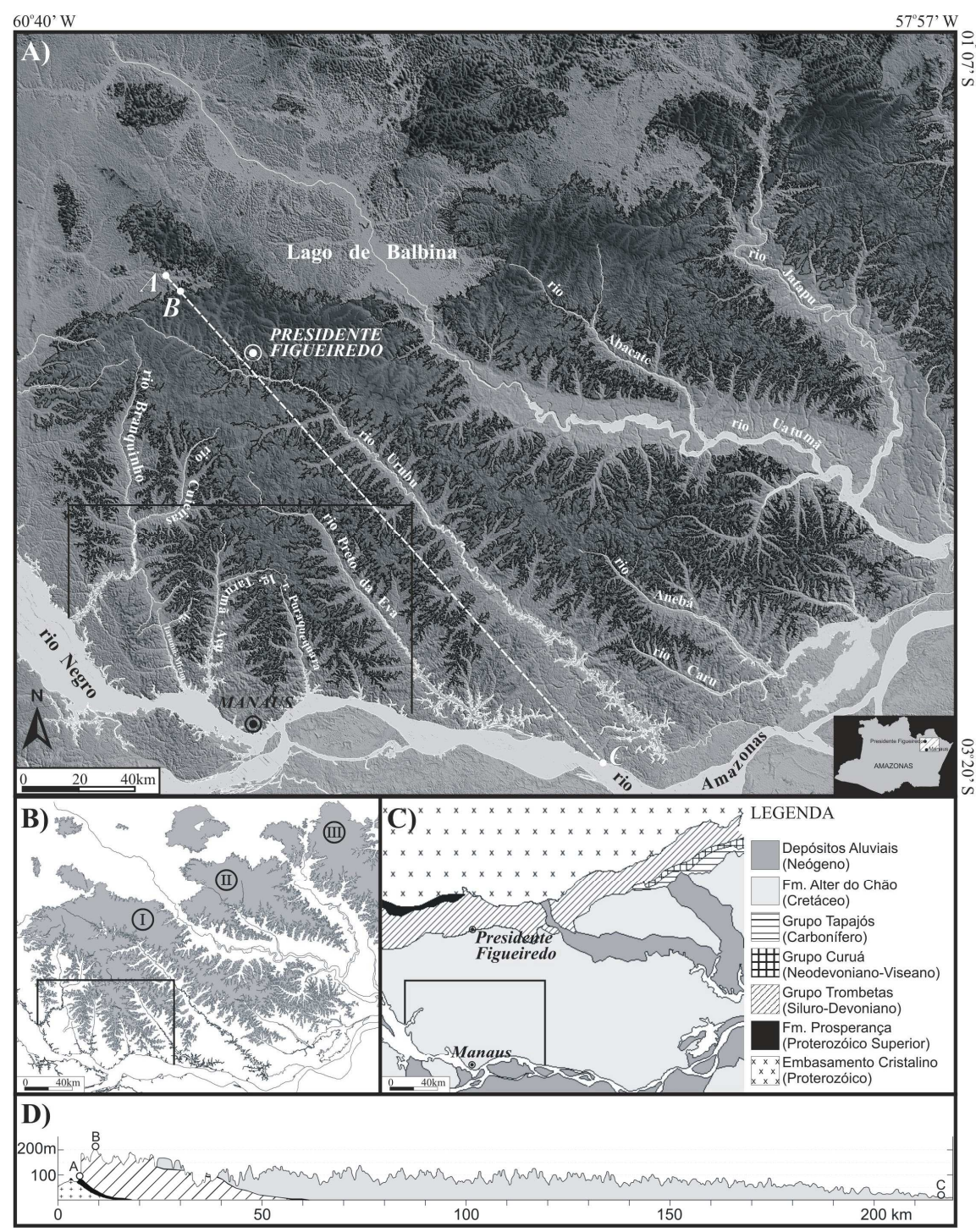

Figura 5.1: Contextualização da área de estudo na região nordeste do estado do Amazonas. A) Distribuição dos divisores topográficos, desenvolvidos sobre as rochas sedimentares da Bacia do Amazonas. A área de estudo, delimitada pela linha preta situada entre os rios Cuieiras e Preto da Eva, está desenvolvida sobre o domínio geomorfológico Planalto Dissecado Rio Trombetas - Rio Negro (Nascimento et al. 1976). B) Em destaque, os conjuntos topográficos (I, II e III), com limite das curvas de nível em 90m, individualizados pelos canais dos rios Negro, Uatumã e Jatapu. C) Distribuição das unidades geológicas da região (adaptado de Nogueira \& Sarges 2001, Rosseti et al. 2005, Nogueira et al. 2006), sobre as quais estão desenvolvidos os conjuntos topográficos, com representação do limite da área de estudo pela linha preta. D) Perfil topográfico com direção azimutal de 140, onde estão contidos os máximos e mínimos altimétricos, respectivamente pontos $\mathrm{B}$ e $\mathrm{C}$, do conjunto topográfico I. 
O desnível topográfico entre o limite da borda norte e o limite sul, está representado no perfil topográfico $\mathrm{ABC}$ (Fig. 5.1D). $\mathrm{O}$ trecho $\mathrm{AB}$, que abrange o contato entre a borda norte da Bacia do Amazonas e o embasamento Proterozóico, apresenta variação de altitude de $203 \mathrm{~m}$ para $44 \mathrm{~m}$ em uma distância de $9 \mathrm{~km}$. No segmento BC, que representa os desníveis altimétricos do conjunto topográfico 1, a altitude decresce gradualmente de $203 \mathrm{~m}$ para $14 \mathrm{~m}$ em $204 \mathrm{~km}$ de distância, em direção ao rio Amazonas. A ocorrência do acentuado desnível topográfico no segmento $\mathrm{AB}$ tem relação direta com a preservação dos interflúvios tabulares nesta porção setentrional, enquanto a sul tendem a apresentar formas tabulares com maior dissecação nas proximidades das margens dos rios Amazonas, Negro, Cuieiras, Rio Preto da Eva e Uatumã, que correspondem aos rios de maior porte da área (Fig. 5.1A).

\section{MATERIAL E MÉTODOS}

Estudos geomorfométricos no estado do Amazonas sempre foram preteridos devido à precária cobertura topográfica da região, onde apenas a porção sul da área urbana da cidade de Manaus (Fig. 1.1, item 1.1) possui cobertura topográfica que possibilita estudos geomorfométricos que subsidiou a elaboração da Carta de Declividades de Manaus (Bento \& Frota 1999). Neste contexto, os MDE's disponibilizados pelo USGS (2003), resultantes da missão SRTM (Hennig et al. 2001), com as devidas correções necessárias (Barros et al. 2004, Santos et al. 2005), constituem uma solução alternativa para os históricos problemas de cartografia topográfica da região amazônica.

Análises cartográficas realizadas por Santos et al. (2005) confirmam que os MDE's SRTM apresentam PEC (Padrão de Exatidão Cartográfico) de categoria A, definido pelas normas brasileiras de cartografia, com erro médio quadrático de 11,066 m e 97,75 \% dos pontos abaixo da tolerância vertical em escala de 1:100.000. Sendo assim, a partir destes 
MDE's é possível a aquisição de variáveis geomorfométricas (Valeriano 2004, Valeriano et al. 2006, Grohmann et al. 2007), viabilizando os estudos geomorfométricos na região de Manaus.

A caracterização morfológica da região em estudo, que possui extensão de $7.295 \mathrm{~km}^{2}$ e perímetro de $366 \mathrm{~km}$ e está inserida entre as coordenadas geográficas $2^{\circ} 30^{\prime} 00^{\prime \prime} \mathrm{S}$ e $60^{\circ} 30^{\prime} 00^{\prime \prime} \mathrm{W}$ a $3^{\circ} 15^{\prime} 00^{\prime \prime} \mathrm{S}$ e $59^{\circ} 30^{\prime} 00^{\prime \prime} \mathrm{W}$, foi realizada por meio da análise de parâmetros geomorfométricos adquiridos dos MDE's SRTM (USGS 2003). Aos MDE's foram adicionados, ainda, os lagos e canais de drenagens, digitalizadas a partir de cartas topográficas na escala 1:100.000.

O reconhecimento das feições de relevo da área constou assim de diferentes etapas de trabalho: a) uma primeira caracterização foi fundamentada na análise da distribuição e nos contornos das formas na definição dos macro-compartimentos do relevo da área a partir da elaboração do mapa hipsométrico e do reconhecimento de diferentes faixas altimétricas (Strahler 1952), além dos valores de declividades das encostas; b) compartimentação topográfica a partir da aplicação da base metodológica fundamentada no cálculo do índice de desnivelamento altimétrico de bacias de drenagem formadoras dos sistemas fluviais (Meis et al. 1982, Silva 2002); c) e na identificação de feições morfotectônicas, relacionadas a aspectos morfográficos e morfogenéticos, utilizando análises de superfícies de base, declividades, densidade de lineamentos e densidade de drenagem (Horton 1945, Golts \& Rosenthal 1993, Hiruma \& Riccomini 1999). A caracterização morfológica foi complementada por análises do arranjo da rede de drenagem e classificação dos padrões de drenagem, seguindo proposta de Howard (1967). 


\section{CARACTERÍSTICAS DO RELEVO DA REGIÃO DE MANAUS}

A distribuição das formas de relevo em função da variação altimétrica permitiu a definição de cinco faixas hipsométricas (Fig. 5.2A), que mostram a relação entre a distribuição e organização espacial das feições geomórficas da área. Em porções da área com altitudes inferiores a $25 \mathrm{~m}$ que abrangem os vales dos rios Amazonas, Negro, Cuieiras, Tarumã Açu, Tarumã Mirim, Puraquequara e Preto da Eva, ocorrem feições morfológicas de barras de canais e planícies de inundação de grandes extensões. O intervalo altimétrico entre 25 e 65m, que coincidem com vales e planícies de tributários dos rios Negro e Amazonas, é constituído por terraços fluviais e terraços erosivos. A faixa altimétrica entre 65 e $90 \mathrm{~m}$ abrange as vertentes dos interflúvios tabulares estreitos e com elevado grau de dissecação. O intervalo altimétrico entre 90 e $115 \mathrm{~m}$ é representativo dos divisores de drenagens ramificados e alongados na direção NW-SE e N-S, com ampla distribuição em área. A faixa altimétrica maior que $115 \mathrm{~m}$ engloba os topos planos dos divisores tabulares, com distribuição restrita na porção centro-norte da área.

Em relação à declividade da região, a área apresenta baixos valores de declividades, com gradiente máximo de $18^{\circ}$ (Fig. 5.2B). As maiores declividades, entre $12^{\circ}$ e $18^{\circ}$ (representadas pela cor preta na figura 5.2B), ocorrem nas bordas dos terraços fluviais e nas vertentes dos interflúvios alongados de topos planos. As vertentes dos interflúvios intensamente dissecados apresentam declives com ângulo entre $6^{\circ}$ e $11^{\circ}$, enquanto os segmentos com menores declividades $\left(0^{\circ}-5^{\circ}\right)$, representadas pela cor branca, correspondem aos fundos de vales, nas planícies e nos topos dos interflúvios tabulares. 

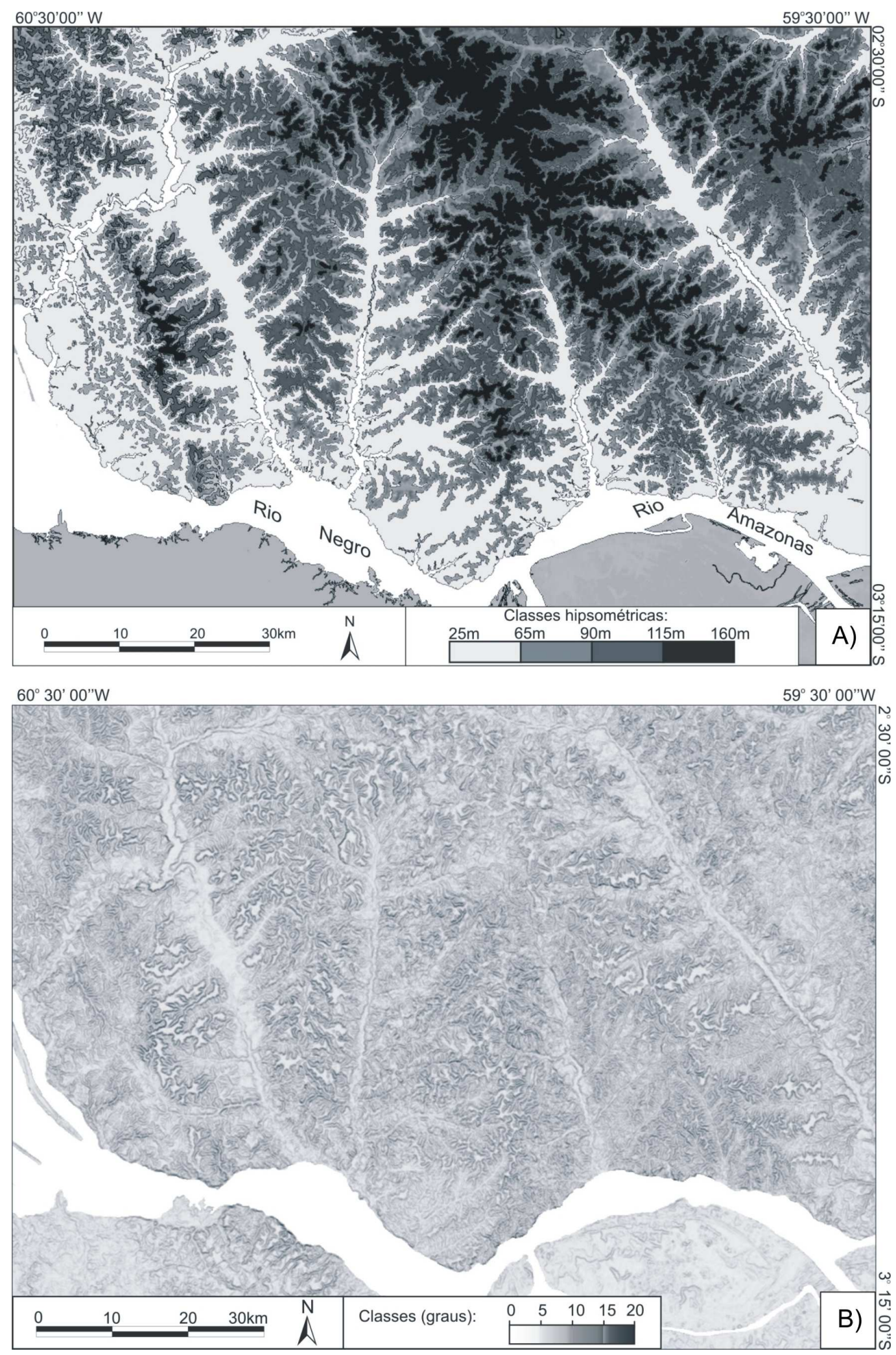

Figura 5.2: Apresentação das características do relevo da área de estudo. A) Delimitação das faixas altimétricas representativas da distribuição e organização das formas de relevo no mapa hipsométrico B) Ângulos de declividades associados às feições geomórficas, no mapa de declividades. 
Os desníveis topográficos da região de Manaus refletem o elevado grau de incisão fluvial e entalhamento erosivo das vertentes, mecanismos estes que devem estar associados às variações tectônicas (Meis et al. 1982, Silva et al. 1995), uma vez que a litologia da área é constituída essencialmente por rochas sedimentares, geralmente friáveis em função do intenso intemperismo atuante na região.

Na compartimentação topográfica foram reconhecidas três classes de desnivelamento altimétrico, com interpretação do significado geomorfológico atribuído a cada classe (Fig. 5.3). O compartimento com altimetria entre 25 e $50 \mathrm{~m}(\Delta \mathrm{h}<50 \mathrm{~m})$ abrange os terraços fluviais, terraços erosivos e planícies de inundação. A porção entre os rios Cuieiras e Tarumã Mirim, que representa um domínio fisiográfico isolado do conjunto topográfico I (Fig. 5.1A), compreende desnivelamento altimétrico entre 25 e $100 \mathrm{~m}(\Delta \mathrm{h}=75 \mathrm{~m})$ e reúne feições geomórficas constituídas por interflúvios tabulares dissecados com topos mais convexizados. A região entre os rios Tarumã Mirim e Preto da Eva corresponde ao compartimento predominante da área de estudo, com desnivelamento altimétrico entre 50 e 160m $(\Delta \mathrm{h}>100 \mathrm{~m})$, composta por interflúvios tabulares com topos planos e presença de depressões. 


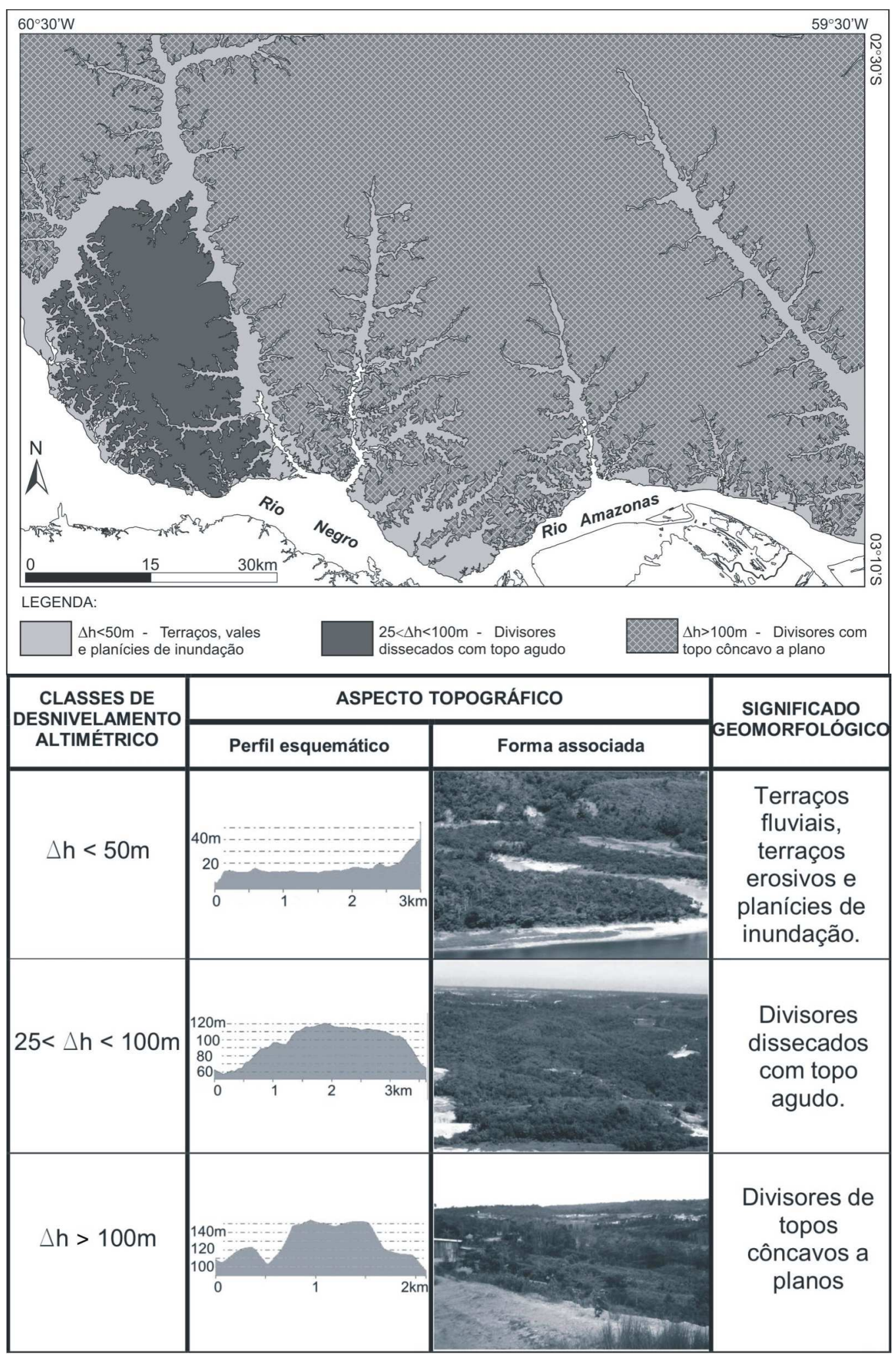

Figura 5.3: Mapa de compartimentação topográfica, com delimitação de três classes de desnivelamentos. As características das classes de desnivelamento altimétricos $(\Delta \mathrm{h})$, com ilustração do perfil topográfico representativo e feições geomórficas correspondentes, são apresentadas no quadro inferior. 


\section{ANOMALIAS GEOMÓRFICAS IDENTIFICADAS}

A paisagem da região amazônica apresenta elementos indicadores da atuação de movimentação tectônica, exemplificados por alinhamentos de feições geomórficas e elementos da rede de drenagem, tais como canais de drenagens e de desembocaduras, feições anômalas nos canais de drenagem, tais como trechos retilíneos, inflexões abruptas, desembocaduras afogadas ("rias fluviais"), capturas de drenagens, inflexões anômalas em segmentos de canais, cachoeiras condicionadas por falhas e desníveis entre margens dos canais (Sternberg 1950, Forsberg et al. 2000, Costa et al. 2001, Nogueira \& Sarges 2001, Franzinelli \& Igreja 2002, Almeida-Filho \& Miranda 2007).

A distribuição espacial dos canais de drenagem mostra uma tendência de fluxo radial para o sul e elevados valores de densidade de drenagem na área com distribuição relativamente uniforme. Os valores mais elevados ocorrem ao longo das calhas coletoras principais e nas desembocaduras afogadas. Baixas concentrações de canais de drenagem são observadas nas áreas dos interflúvios de topos planos e no extremo sul da área (Fig. 4A).

A análise de superfície de bases buscou definir elementos indicativos de controle tectônico paisagem, revelados por desvios abruptos, estreitamentos e distanciamentos das isolinhas (Fig. 5.4B). Observou-se que os alinhamentos de isolinhas NW-SE são associados principalmente com orientações de canais de drenagem, enquanto que na direção NE-SW apresentam correlação com alinhamentos de interflúvios. A assimetria das isolinhas está relacionada ao estilo do relevo da região, que configura um platô com dissecação nas bordas (Fig. 5.4B).

Existe uma relação entre os canais de drenagem e a distribuição dos lineamentos na área, evidenciada principalmente pelas concentrações mais elevadas de lineamentos nas adjacências dos rios Cuieiras, Tarumã Mirim, Tarumã Açu e Puraquequara. Curiosamente, ocorre uma baixa concentração de lineamentos ao longo do rio Preto da Eva. A orientação 
preferencial NE está concentrada nos intervalos $35^{\circ}-55^{\circ}$, mas estão presentes expressivos lineamentos na direção N-S e na direção NW (Fig. 5.5A).
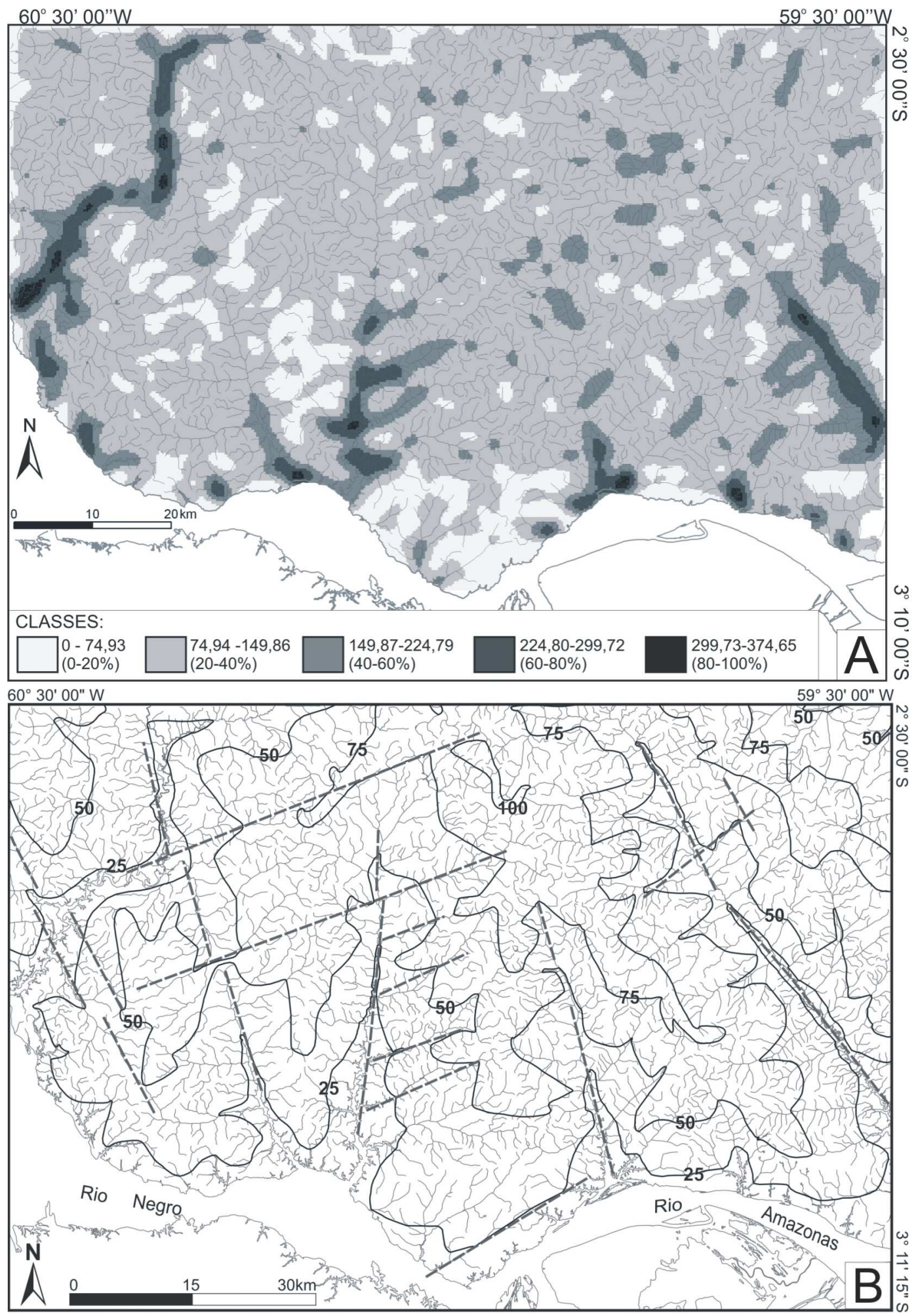

Figura 5.4: A) Mapa de densidade de drenagem, mostrando as concentrações de canais de drenagem em porcentagem por $\mathrm{km}^{2}$. B) Mapa de superfície de base, com interpretação de alinhamentos associados a possíveis estruturas e comportamento das isolinhas. 

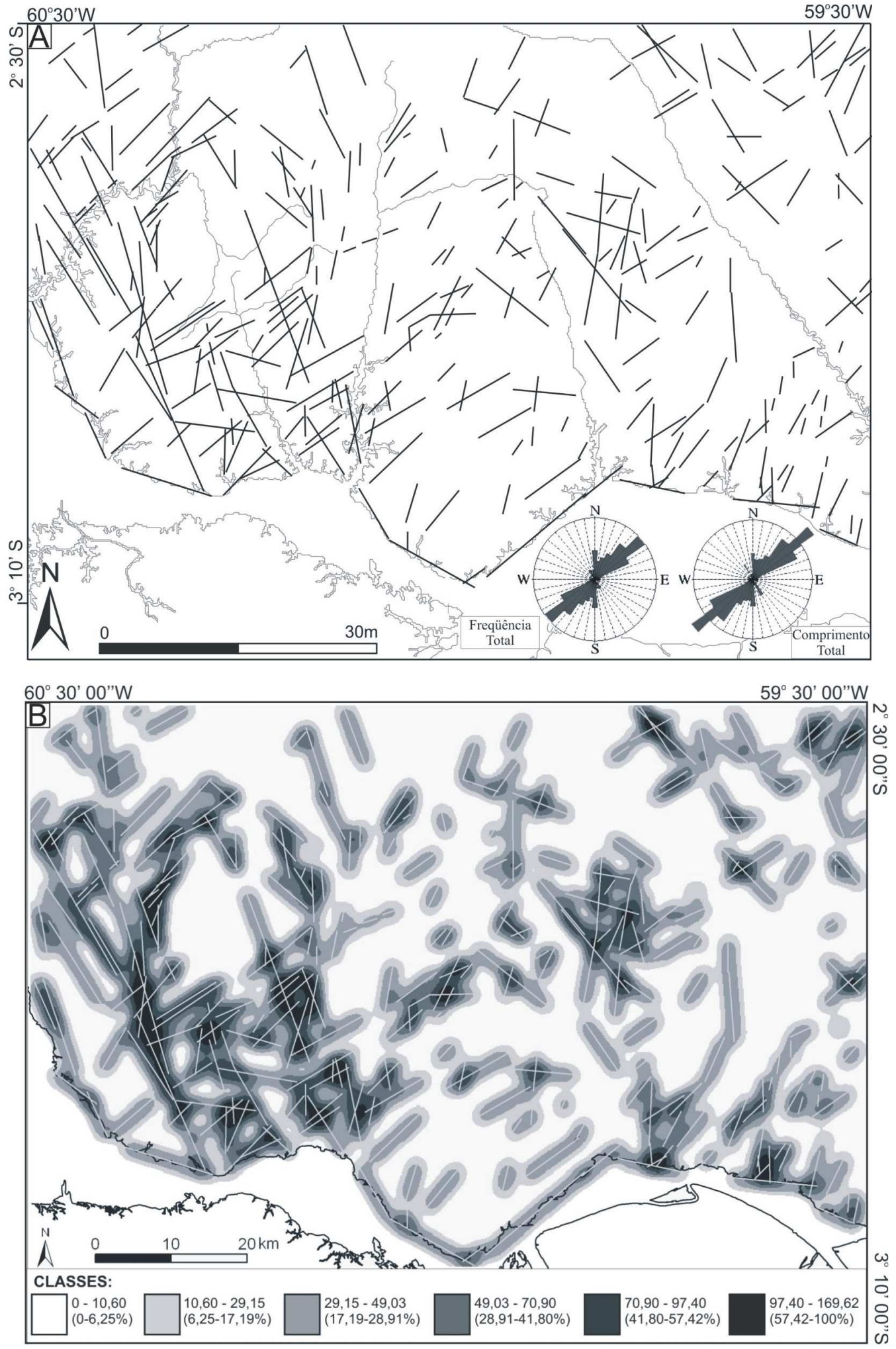

Figura 5.5: A) Lineamentos interpretados a partir de imagem de relevo sombreado, com elevação de iluminação $45^{\circ}$ e azimutes NE e SE, que perfazem um total de 300 lineamentos distribuídos em uma área de $7.295 \mathrm{~km}^{2}$. Os diagramas de rosetas mostram a relação da orientação dos lineamentos conforme quantidade e o comprimento total. B) Mapa de densidade de lineamentos, mostrando as áreas com concentração dos lineamentos. 
Embora em menor quantidade, os lineamentos NW são os mais extensos da área e controlam importantes segmentos da paisagem, como os limites do compartimento topográfico com $\Delta \mathrm{h}=75 \mathrm{~m}$, bem como o alinhamento de interflúvios deste compartimento, e orientações de canais de drenagens (Fig 5.5A). Em relação ao arranjo espacial, a maior concentração de lineamentos ocorre na porção entre os rios Cuieiras e Tarumã Mirim (Fig. 5.5B).

\section{CONCLUSÕES SOBRE A EVOLUÇÃO DO RELEVO}

A configuração do relevo da região é uma resposta às mudanças ocorridas na rede de drenagem da região amazônica, possivelmente no Paleógeno (Hoorn et al. 1995, Mapes et al. 2006), que culminou com a elaboração dos conjuntos de divisores topográficos desenvolvidos sobre as rochas sedimentares da Bacia do Amazonas (Figs. 5.1A e B). As análises geomorfológicas realizadas permitem sugerir que as modificações foram condicionadas à atuação de atividades tectônicas na região, sendo identificadas duas fases de reorganização da rede de drenagem na região de Manaus.

Na primeira fase, marcada pela reversão do fluxo do rio Amazonas no Neomioceno em razão do soerguimento Andino (Hoorn et al. 1995, Mapes et al. 2006), os canais de drenagem da área apresentavam concordância de fluxo para sul, com a presença do interflúvio entre o rio Negro e o paleo-rio Branquinho (Fig. 5.6).

Uma segunda atividade tectônica condicionou a modificação local no sistema de drenagem, com alteração do curso do rio Cuieiras, ocorrendo aumento do comprimento de seu canal, e do rio Branquinho, que teve o canal reduzido, e geração do igarapé Tarumã Mirim. Esta captura é indicada pela inflexão anômala do rio Cuieiras de NW para SW, em um ângulo de $90^{\circ}$, como reflexo de movimentação tectônica que afetou a região, imprimiu as inflexões 
anômalas em trechos do canal deste rio e ocasionou a captura de drenagem da cabeceira do igarapé Tarumã Mirim (Fig. 5.6).

A captura de canais de drenagem é resultante da modificação da direção do fluxo e a intercisão de canais (Deffontaines \& Chorowicz 1991), no qual o ponto onde ocorre a captura do canal é marcado por mudança brusca na direção do fluxo, frequientemente da ordem de $90^{\circ}$ (Summerfield 1991). A origem do compartimento topográfico $\Delta \mathrm{h}=75 \mathrm{~m}$ esta fase está relacionada à segunda fase de rearranjo da rede de drenagem, associado à formação de um bloco alto com falhas normais com mergulhos para NW e SE (Fig. 5.6).

Os lineamentos apresentam relação com a distribuição dos interflúvios tabulares, dissecação nas bordas dos interflúvios, limites do compartimento topográfico $\Delta \mathrm{h}=75 \mathrm{~m}$ e direção de fluxo dos rios (Figs. 5.2, 5.3 e 5.4). Os lineamentos NW-SE e NE-SW, que ocorrem na região do rio Cuieiras (Fig. 5.3), estão associados ao evento tectônico responsável pela captura de drenagem do rio Branquinho pelo rio Cuieiras.

A reconstituição da paleotopografia posterior ao evento de captura de drenagem foi simulada com base nos dados de superfície de bases, pois o arranjo espacial das isolinhas revela a configuração da superfície topográfica original de uma área (Golths \& Rosenthal 1993). O relevo original de grande platô era caracterizado pela existência de duas superfícies de aplainamento, correlacionadas às superfícies S1 e S2 definidas por Horbe et al. (2001), cujo desenvolvimento são associados à Superfície Sul-Americana e a Superfície Velhas, respectivamente. 


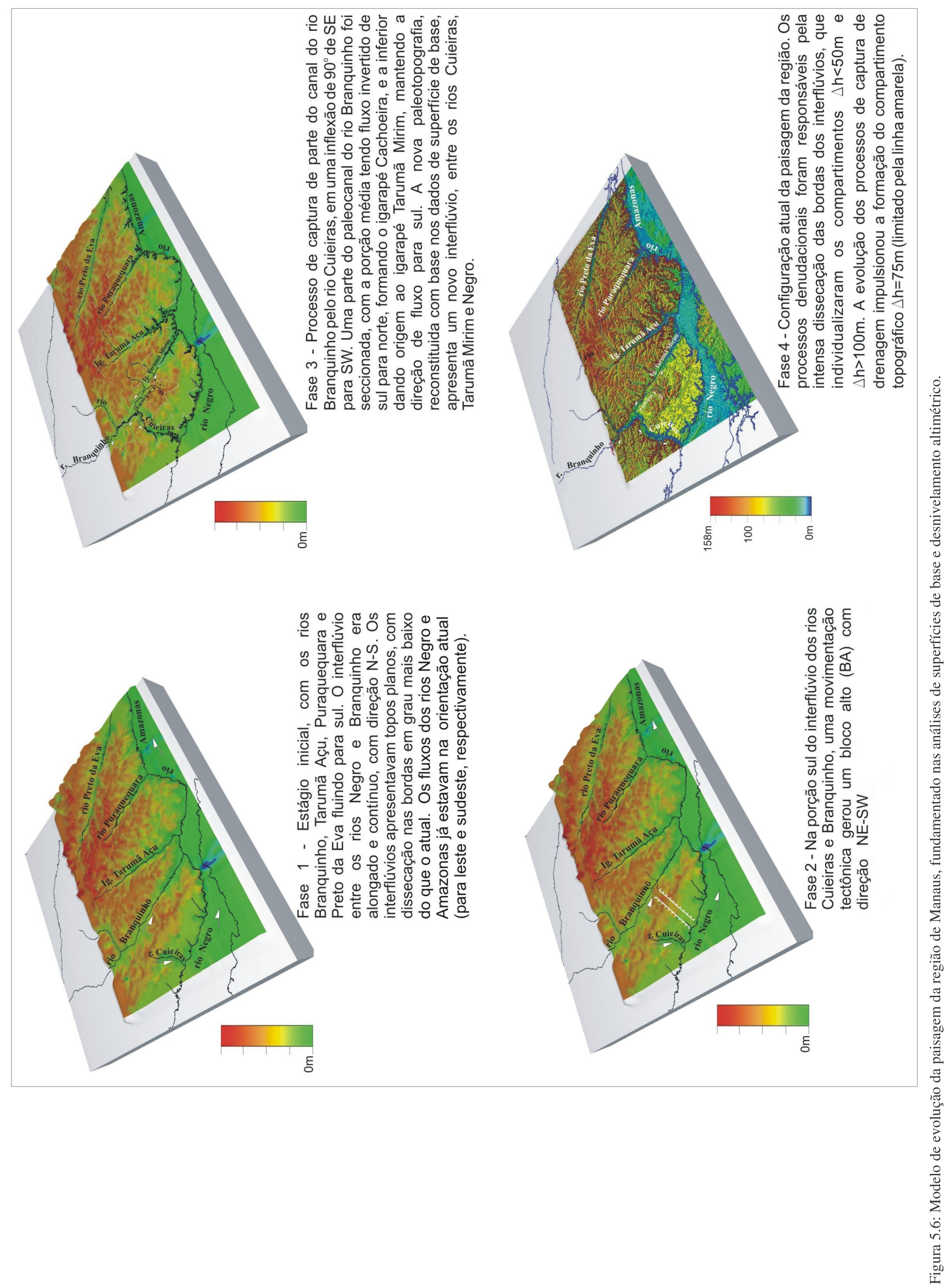


Considerando a relação entre a densidade de drenagem e o padrão de distribuição das isolinhas, a região de Manaus passa por um processo de soerguimento. Segundo Jianjun et al. (1997), num estágio intermediário a tardio de um soerguimento, quando a intensidade do soerguimento é menor ou igual à taxa de incisão fluvial, uma nova formação de ravinas associadas à erosão das cabeceiras resulta em uma rede de drenagem densa, com padrão radial e implantação de canais estreitos, dando uma falsa idéia de subsidência tectônica.

Os processos de denudação, que atuam no desenvolvimento da paisagem atual, promovem uma progressiva mudança da forma de relevo inicial mediante o gradual gradual rebaixamento de topos dos interflúvios e suavização da inclinação das vertentes por processos de intemperismo, erosão e movimentos gravitacionais de massa (Small 1986), resultando na elaboração do escalonamento topográfico, num processo de dissecação regional da área, ilustrado no perfil topográfico $\mathrm{AB}$ (Figs. 5.1A, D), que está associado à formação da superfície S3, proposta por Horbe et al. (2001).

\section{AGRADECIMENTOS}

Os autores agradecem à FAPESP pelo suporte financeiro neste trabalho (Processo 02/09564-0) e pela concessão de bolsa DR a Roseane Sarges. Ao MSc. Gilberto Kaulfuss e MSc. Paulo Santos (IBGE), pelo auxílio e discussões sobre geoprocessamento e cartografia. Ao Dr. Jason Kirk, pela revisão do abstract. 


\section{A INFLUÊNCIA DA TECTÔNICA MESOZÓICA-CENOZÓICA NA PAISAGEM DE MANAUS, AMAZONAS}

A região de Manaus exibe fortes indicadores de movimentos tectônicos cenozóicos, representados por anomalias nos canais de drenagem e deslocamentos de crostas ferruginosas de perfis lateríticos e oxissolos. O impressionante alinhamento dos canais de drenagens da região amazônica em duas direções preferenciais, NE-SW e NW-SE, e a presença de feições retilíneas e ortogonais em trechos de rios chamaram a atenção de Sternberg (1950), que relacionou os sismos recentes da região Amazônica como o principal mecanismo que condicionou a formação das anomalias de drenagens na Bacia Amazônica. Investigações posteriores caracterizaram os aspectos regionais dos eventos tectônicos da região, em registros tanto em feições relacionadas a canais de drenagem (Franzinelli \& Piuci 1988, Bemerguy \& Costa 1991, Hoorn et al. 1995, Forsberg et al. 2000, Costa et al. 2001, Nogueira \& Sarges 2001, Almeida-Filho \& Miranda 2007) como os que produziram deformações em sedimentos e rochas sedimentares da região (Cunha 1990, Costa et al. 1993, Costa et al. 1996, Fernandes Filho et al. 1997, Riccomini \& Soares 2004). A definição da região como uma área tectonicamente ativa foi confirmada por Mioto (1993), que definiu a região sismogênica de Manaus, caracterizada como uma área com instabilidade crustal no interior da Placa SulAmericana, cujos limites são coincidentes com suturas pré-cambrianas orientadas para NWSE e SW-NE. Costa (2002) identificou na região de Manaus uma importante anomalia Bouguer associada a um evento cenozóico, indicada por mudança abrupta na disposição das isolinhas com deslocamento dextral, que estão associados ao conjunto de falhas denominado de Sistema de Falhas Transcorrentes de Urucará, interpretados em seções sísmicas, as quais foram relacionadas a várias reativações ao longo da evolução da Bacia do Amazonas.

A investigação estratigráfica-estrutural realizada na região de Manaus (Fig. 6.1) visou à elaboração do quadro das relações entre os paleocampos de tensões e os prováveis 
mecanismos tectônicos envolvidos em sua formação, buscando acrescentar informações para o entendimento da evolução tectônica da área.

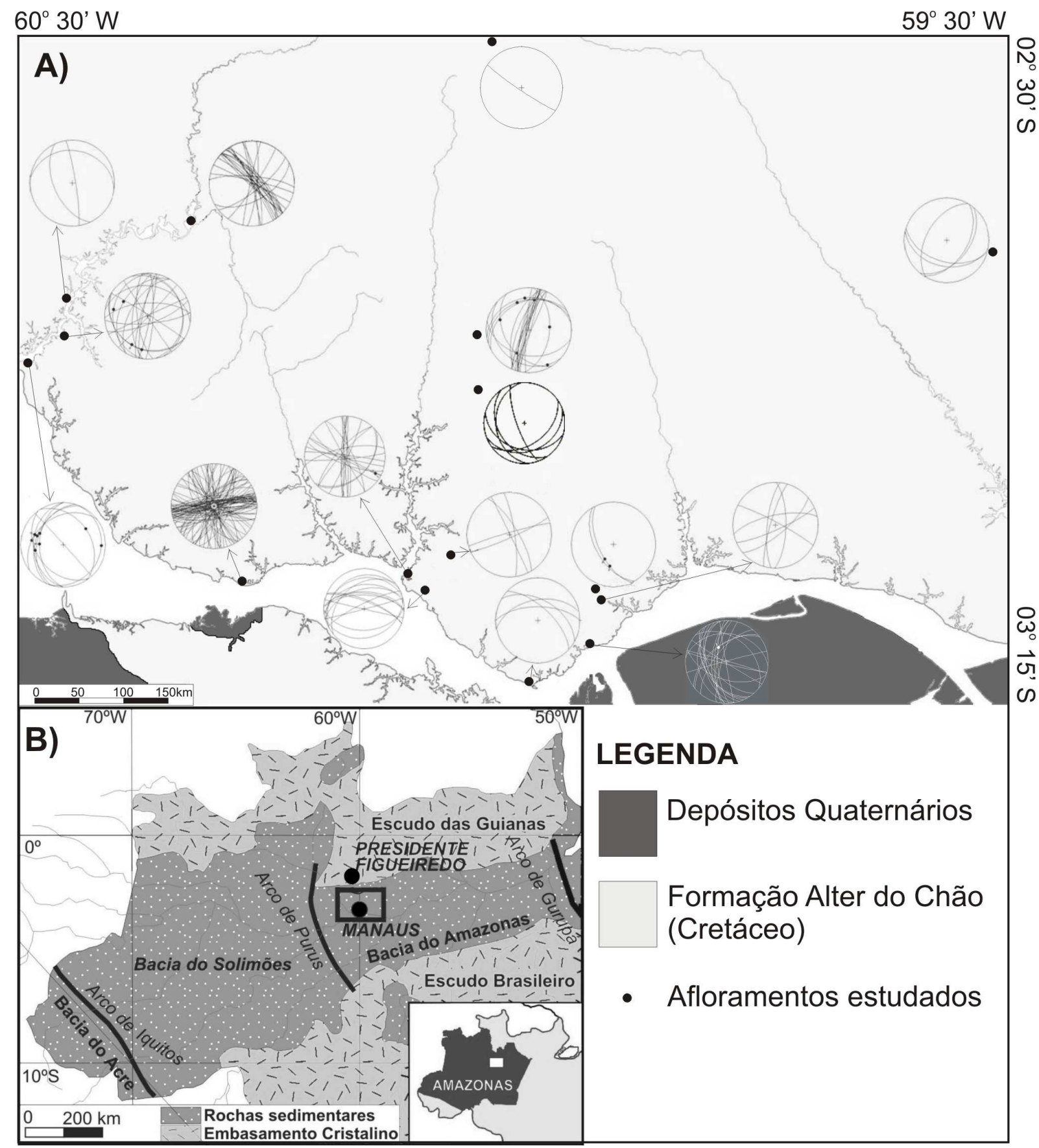

Figura 6.1: Distribuição dos afloramentos estudados sobre as unidades litoestratigráficas da região de Manaus, com representação dos planos das estruturas deformacionais rúpteis medidas (falhas, juntas e fraturas), com projeção Schmidt-Lambert (hemisfério inferior). B) Contexto geológico regional da área, inserida na borda norte da Bacia do Amazonas. 
A caracterização estratigráfica da Formação Alter do Chão, substrato rochoso mais antigo da região de Manaus, fundamentou a obtenção de parâmetros de diferenciação desta com as unidades sobrejacentes, buscando contextualizar cronologicamente os regimes de esforços das movimentações tectônicas cenozóicas na área de estudo, identificados por meio de análise estrutural dos dados medidos em afloramentos. As estruturas deformacionais analisadas são de caráter rúptil, compreendendo falhas, juntas e fraturas não diferenciadas, representadas em diagramas com projeção Schmidt-Lambert, hemisfério inferior. Estas estruturas foram medidas em sua grande parte nos arenitos e siltitos da Formação Alter do Chão e em horizontes ferruginosos dos perfis lateríticos. Na análise estrutural para caracterização do esforço e identificação dos campos de tensão (Angelier \& Mechler 1977, Hancock \& Engelder 1989), o sentido do movimento foi determinado em campo, com base em parâmetros estratigráficos e indicadores cinemáticos nos planos de falhas (Petit 1987, Angelier 1994, Doblas et al. 1997), embora esses indicadores cinemáticos normalmente tenham sido obliterados pela ação do intemperismo nesta região tropical.

\subsection{SÍNTESE DO QUADRO TECTÔNICO CENOZÓICO DA REGIÃO DE MANAUS}

A região de Manaus possui uma história tectônica contada em fragmentos, com análises pontuais sobre os registros deformacionais, ou modelos regionais com poucos dados coletados em superfície, muitas vezes fundamentados em produtos de sensores remotos, por estes constituírem a alternativa mais viável para análises regionais, em função das condições inerentes à região amazônica.

Os lineamentos NW-SE e NE-SW, as falhas normais NW e falhas direcionais presentes na região de Manaus foram correlacionados a uma transcorrência dextral E-W por 
Franzinelli \& Igreja (1990). Concordando com esta interpretação, Fernandes Filho et al. (1995, 1997) ainda acrescenta um pulso de transcorrência dextral NE-SW, atuante no intervalo Pleistoceno-Holoceno. Para Costa et al. (2001) as transcorrências dextrais E-W e NE-SW teriam ocorrido no Mioceno-Plioceno, documentadas na área entre os rios Preto da Eva e Urubu. No intervalo Pleistoceno-Holoceno elas teriam sido sucedidas por dois novos pulsos de transcorrentes (Costa et al. 2001), que teriam condicionado a orientação da rede de drenagem moderna. As falhas normais NE-SW e NNW-SSE, que incluem falhas sindeposicionais na Formação Alter do Chão, são admitidas por Silva (2005) como geradas por esforços distensivos cretáceos. As falhas inversas NE-SW foram admitidas por Silva (2005) como miocenas e relacionadas à paleotensões com $\sigma 1$ NW-SE, $\sigma 2$ NE-SW e $\sigma 3$ subvertical, associadas à atuação de esforços compressivos NE-SW. Entretanto, estes esforços NE-SW identificados pelo autor são incompatíveis com as paleotensões também por ele propostas.

\subsection{REGIMES DE ESFORÇOS ATUANTES NA PORÇ̃̃O NORTE DA PLACA SUL-AMERICANA}

O quadro deformacional Cenozóico na região de Manaus tem sua evolução correlacionada à ação combinada de tensões admitidas como resultantes da complexa interação de esforços entre as placas do Caribe, Cocos, Nazca e Sul-Americana (Costa 2002, Colmenares \& Zoback 2003). Os principais reflexos desta interação no domínio intraplaca são tensões compressivas E-W, que agem na área submersa, enquanto a tensão horizontal mínima $\left(\mathrm{Sh}_{\text {mín }}\right)$, de caráter distensivo e atuante na área emersa, imprimem esforços direcionais (Zoback et al. 1989, Assumpção 1992, Coblentz \& Richardson 1996). 
Os reflexos da interação destas tensões no quadro tectônico são considerados principalmente no condicionamento da rede de drenagem e no desenvolvimento da paisagem da região (Hoorn et al. 1995, Costa et al. 2001, Franzinelli \& Igreja 2002, Almeida-Filho \& Miranda 2007, entre outros). Uma diferenciação das tensões intraplaca resultantes da interação dos esforços entre as placas Sul-Americana, Caribe e Nazca foi proposta por Colmenares \& Zoback (2003), onde esforços compressivos E-W, relacionados ao processo de subducção da placa de Nazca sob a placa Sul-Americana, atuariam nos Andes Equatorianos, enquanto no noroeste da placa Sul-Americana ocorreria compressão NW-SE, resultante da subducção da Placa do Caribe sob a placa Sul-Americana ou da colisão contínua da microplaca Costa Rica-Panamá, e na Venezuela Setentrional ocorreriam esforços distensivos NE-SW.

\subsection{ANÁLISE ESTRUTURAL E IDENTIFICAÇÃO DE CAMPOS DE TENSÃO}

\subsubsection{ESTRUTURAS IDENTIFICADAS E SUAS RELAÇÕES COM AS UNIDADES ESTRATIGRÁFICAS}

As estruturas deformacionais analisadas na região de Manaus afetam depósitos sedimentares da Formação Alter do Chão, perfis lateríticos ferruginosos e, por vezes, os solos desenvolvidos sobre a Formação Alter do Chão.

A sucessão sedimentar basal da Formação Alter do Chão, é caracterizada por arenitos, conglomerados e lamitos de cor vermelha, depositados em ambiente fluvial de alta energia. Esta sucessão basal apresenta falhas normais, microfalhas, e laminações convolutas (Figs. 6.2 e 6.3), indicativas de deformação sindeposicional relacionada a esforços distensivos. Falhas normais de direções NE-SW, NW-SE, ENE-WSW e WNW-ESE estão registradas nas 
exposições basais estudadas (Figs. 6.2 e 6.3).

O nível estratigráfico da Formação Alter do Chão denominado na literatura de “Arenito Manaus” (Albuquerque 1922), com expressiva distribuição espacial na região e caracterizado por siltitos, argilitos e arenitos muito silicificados, vermelhos, dentre os quais estão incluídos os paleossolos (Nogueira et al. 1999), foi afetado por intensa atividade tectônica. Falhas normais dextrais NW-SE e NE-SW, e subordinadas falhas normais sinistrais NW-SE estão associadas a juntas com direções NE-SW, NW-SE, WNW-ESE, ENE-WSW, NNE-SSW, NNW-SSE e N-S (Figs. 6.4 e 6.5).
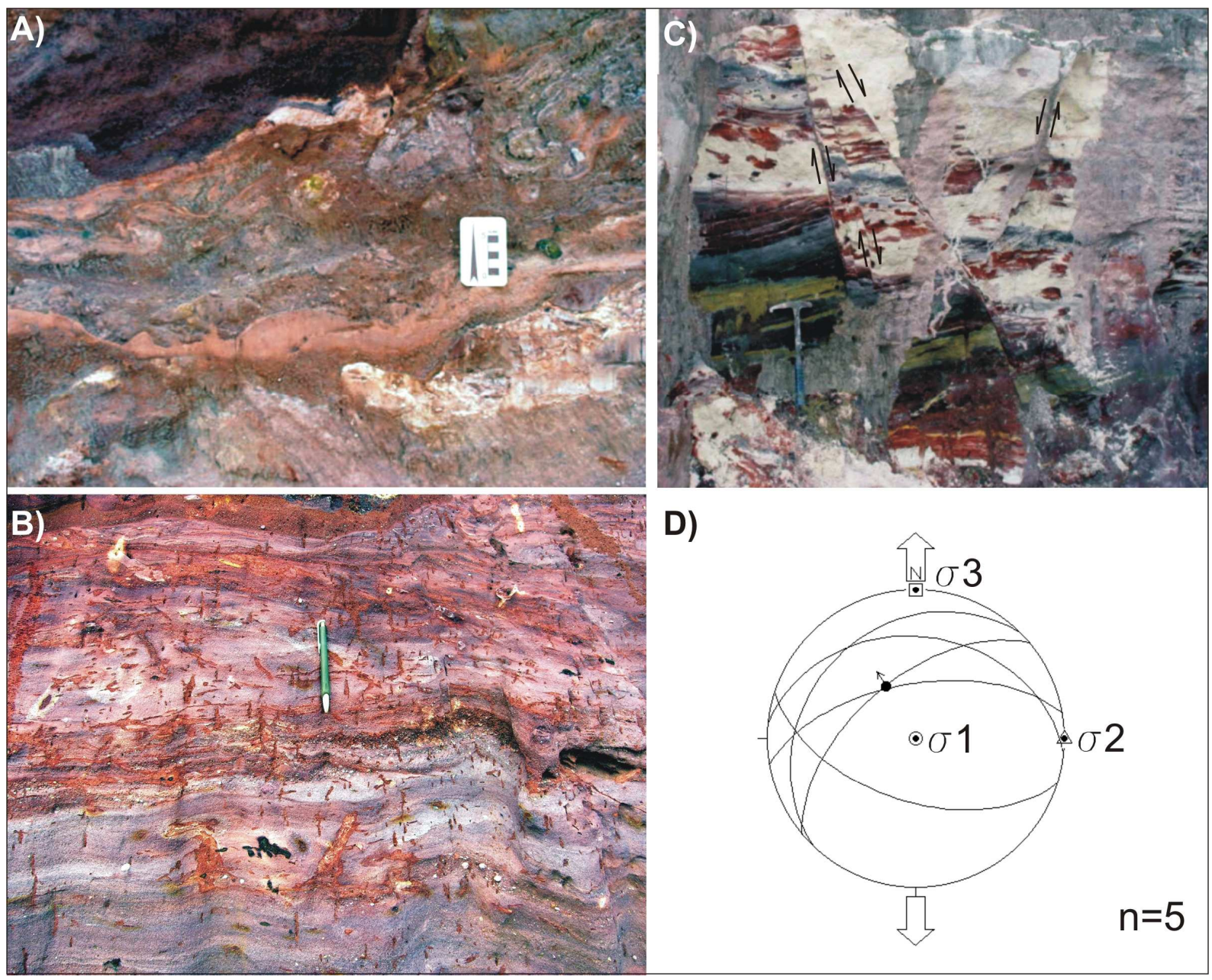

Figura 6.2: Exposição da Formação Alter do Chão na zona leste de Manaus, à margem esquerda do rio Negro, que apresenta laminações convolutas, slumps, camadas interrompidas e diques clásticos (A e B), presentes em camadas intermediárias da sucessão basal desta unidade. Falhas de componentes normais sinsedimentares (C e D) indicam que esforços distensivos estão relacionados à geração destas estruturas deformacionais. 


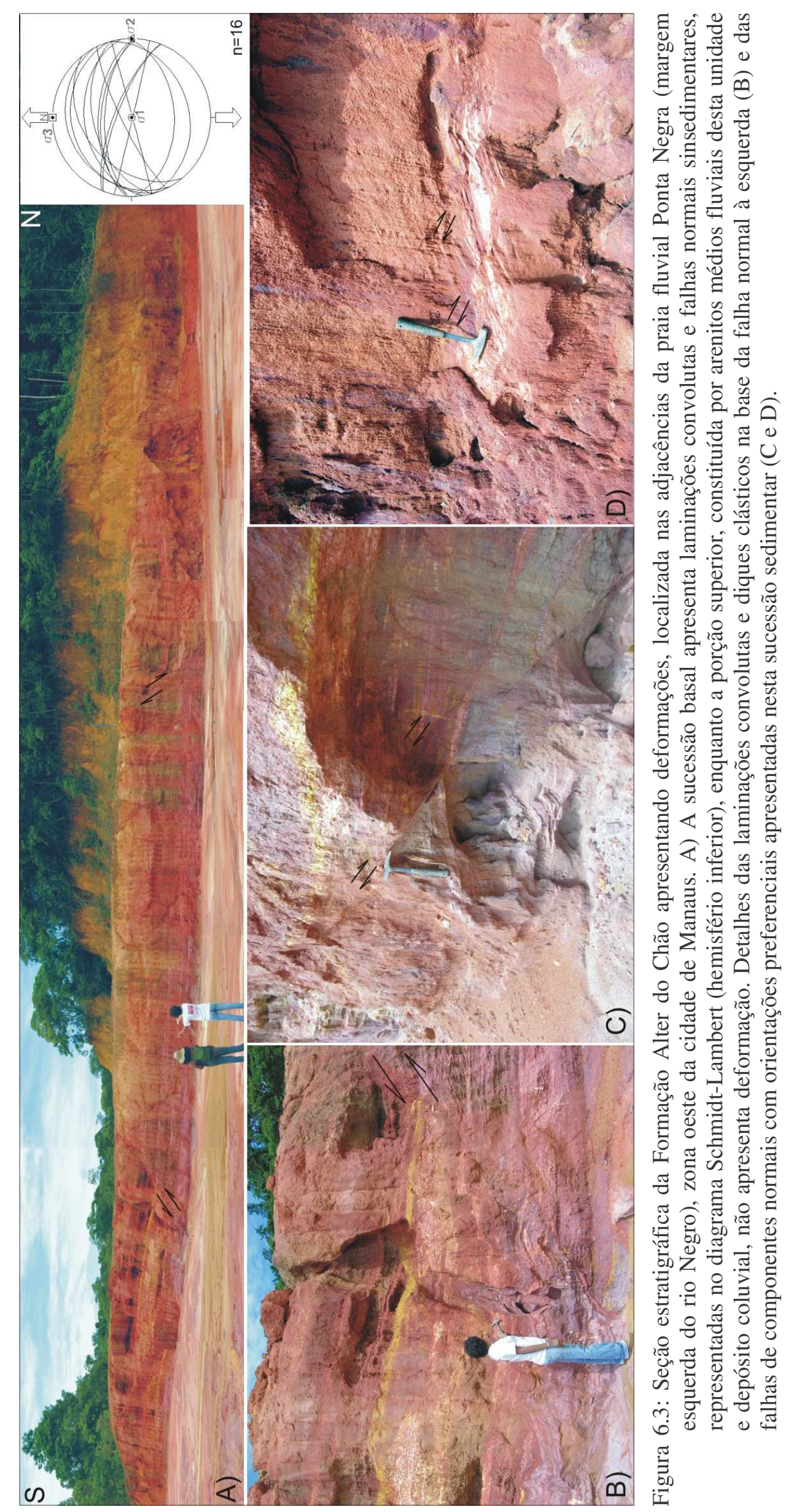



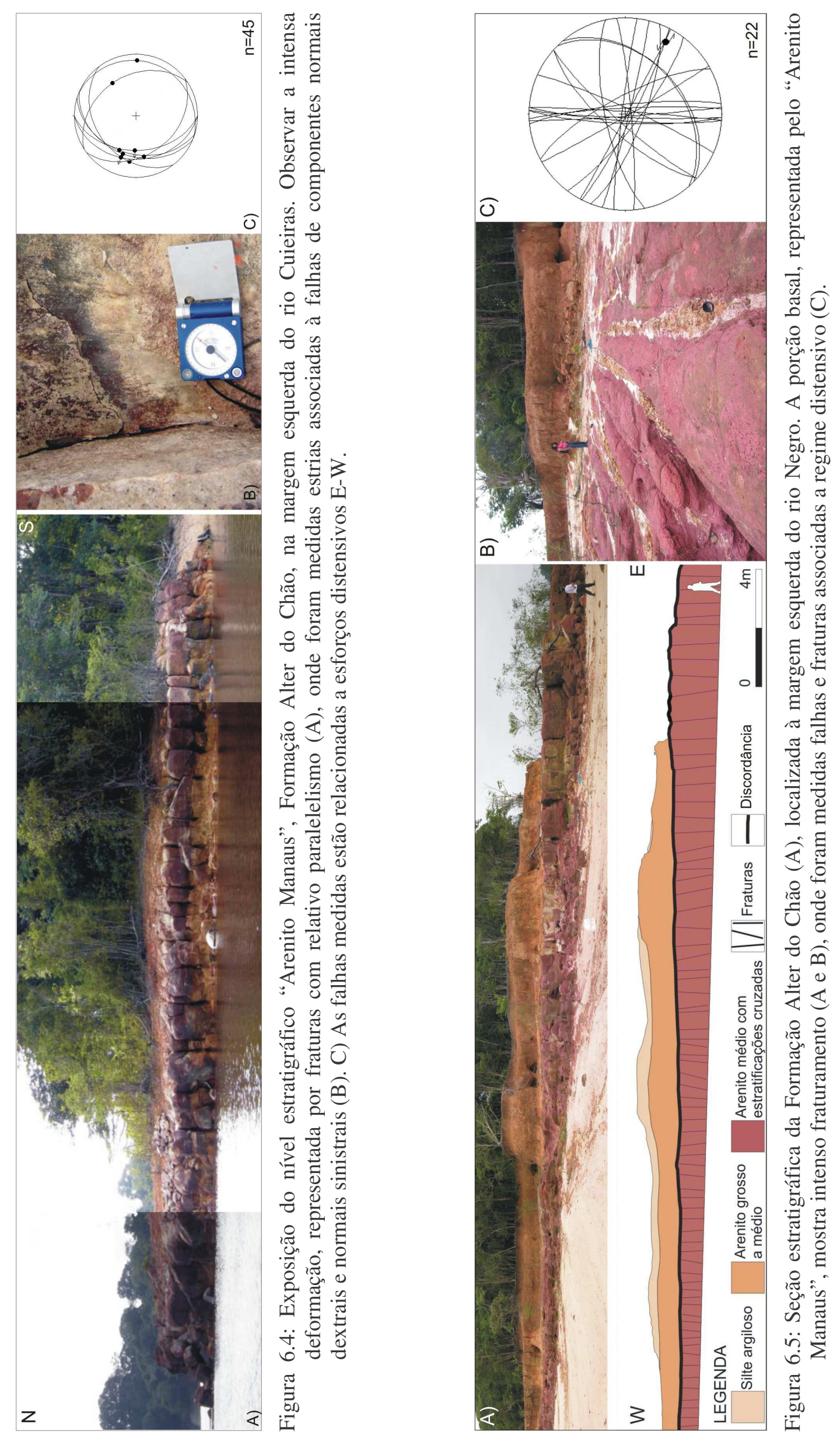

90 
A sucessão sedimentar caracterizada por arenitos médios a grossos caulinícos, com estratificações cruzadas acanaladas e tabulares, representativa do topo da Formação Alter do Chão (Figs. 6.6 e 6.7), apresenta registros de atividades tectônicas que também afetam oxissolos desenvolvidos sobre esta formação, associados à interrupção do processo de formação de perfil laterítico. As estruturas deformacionais compreendem falhas de componentes normais de direção NW-SE, NE-SW e NNW-SSE, juntas NW-SE, NNW-SSE, NE-SW e NNE-SSW. Uma expressiva falha normal NW-SE, com componente lístrico, apresenta rejeito aparente em torno de $6 \mathrm{~m}$ e bascula o solo laterítico com linha de pedra, desenvolvido sobre a Formação Alter do Chão (Fig. 6.7).

Foram identificadas diversas falhas que deslocam e basculam os horizontes ferruginosos dos perfis lateríticos imaturos e linhas de pedras, constituídas por nódulos ferruginosos, desenvolvidos no topo da Formação Alter do Chão. Essas falhas assim medidas apresentam componente normal e estão orientadas nas direções NW-SE, e subordinadamente ENE-WSW, relacionadas à atuação de esforços distensivos NE-SW (Fig. 6.8).

As unidades mais novas contendo registros de movimentações tectônicas foram estudadas na região do rio Cuieiras. Compreendem sucessões constituídas por camadas basais de areias finas argilosas de cor vermelha, sobrepostas por camadas de camadas areias médias a finas de cor cinza (Fig. 6.9), de provável idade pleistocena. Estas camadas estão afetadas por falhas de componente normal de direção NW-SE e subordinadas falhas orientadas na direção NNW-SSE e WNW-ESE, relacionadas a esforços distensivos. 


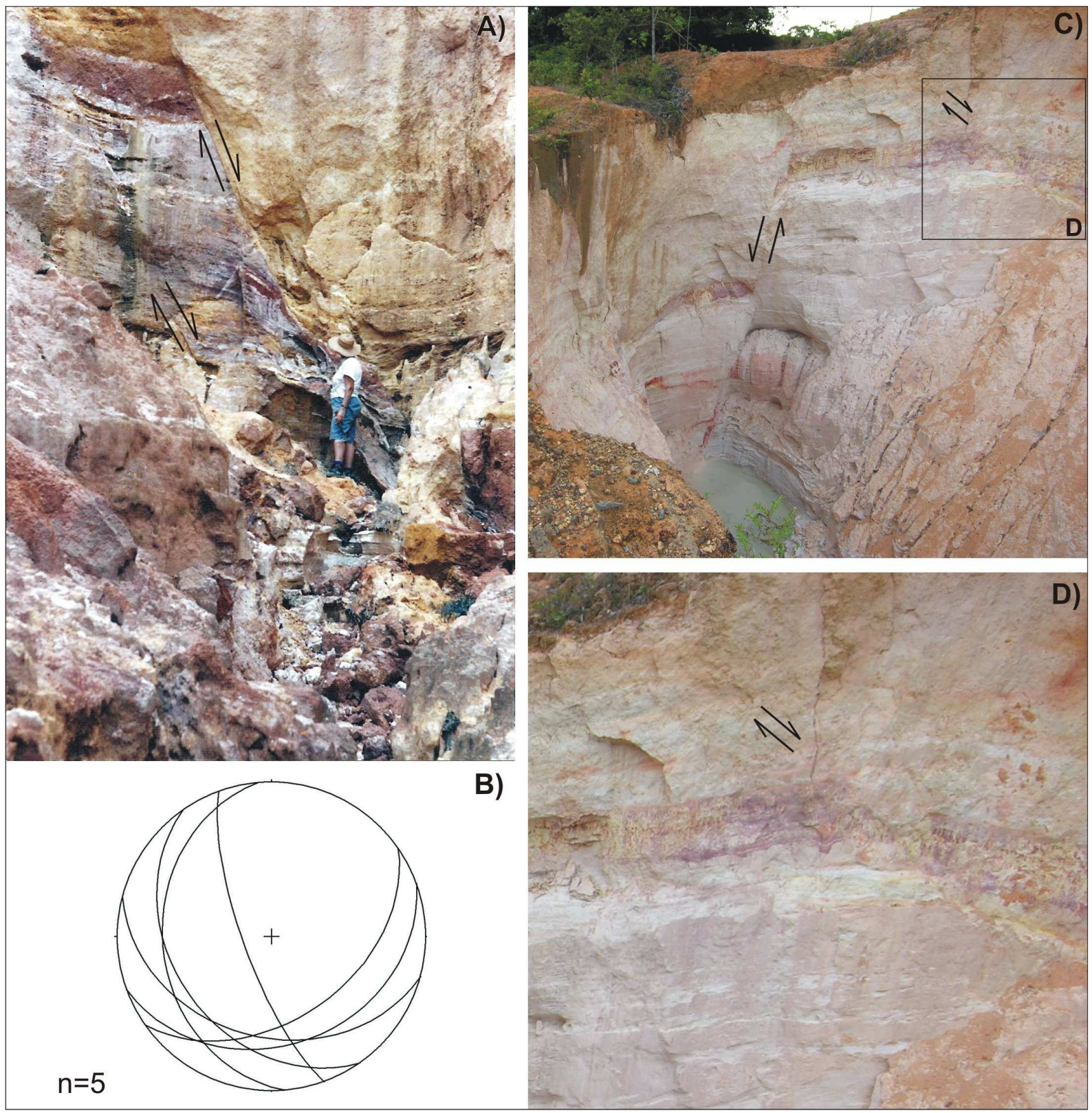

Figura 6.6: Afloramentos de arenitos médios a grossos de coloração rosa a esbranquiçado, correspondentes ao topo da Formação Alter do Chão na região de Manaus, afetados por falhas normais com rejeitos métricos. Nas adjacências do km 10 da rodovia BR-174 (A), os planos de falhas medidos apresentam componentes normais e orientações NW-SE, NE-SW, NNWSSE e WNW-ESE (B). Ainda na BR-174, nas proximidades do $\mathrm{km} \mathrm{8}$, foram observadas falhas normais em uma voçoroca, com direção NW-SE e mergulhos para NE e SW. 

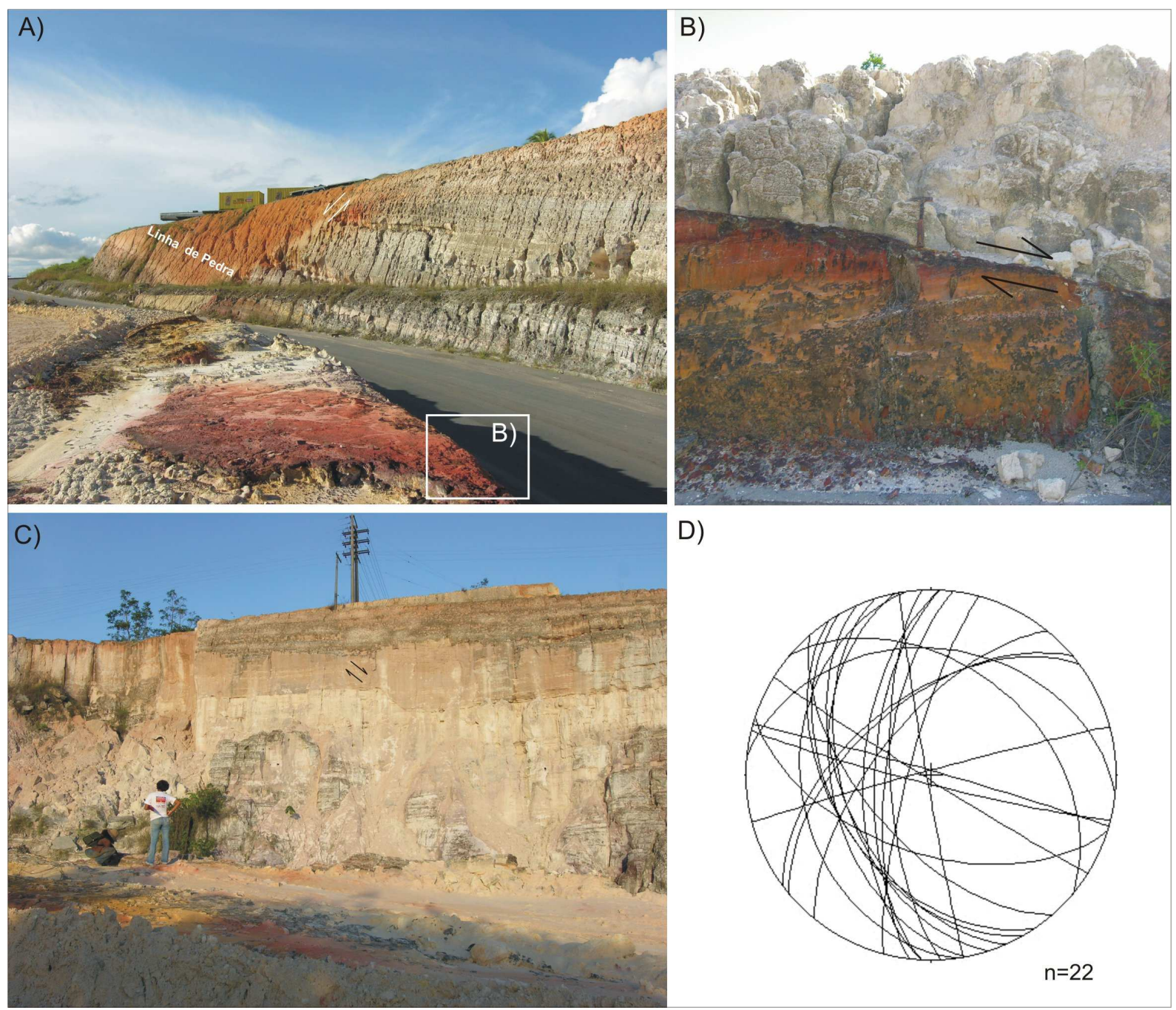

D)

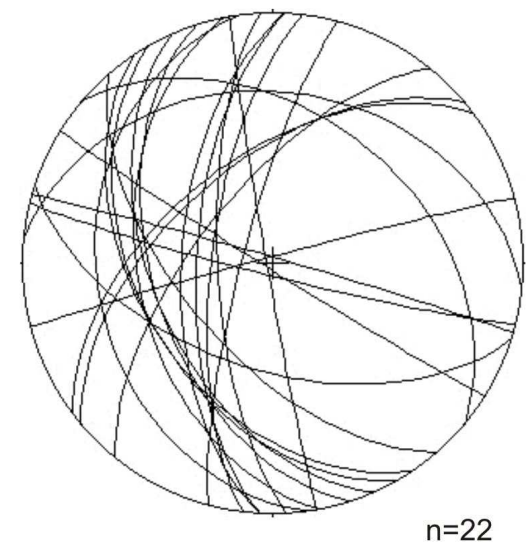

Figura 6.7: Na porção leste de Manaus, no porto da Itautinga, próximo ao encontro da águas dos rios Negro e Amazonas, ocorre o afloramento com mais completo empilhamento sedimentar da Formação Alter do Chão na área de estudo e registros de diferentes fases de deformação tectônica. Falha de componente normal, com atitude N30W/45SW, que afeta também o oxissolo com linha de pedra, apresenta geometria lístrica (A), e intensa ferruginização do plano de falha com atitude N30W/45SW (B). Falhas de componentes normais com atitude N72W/55SW, que afetam somente a sucessão caulinítica inferior (C), indicam um regime de esforço distensivo anterior. As medidas de planos de falhas e juntas associadas ao falhamento curviplanar estão representadas em D. 

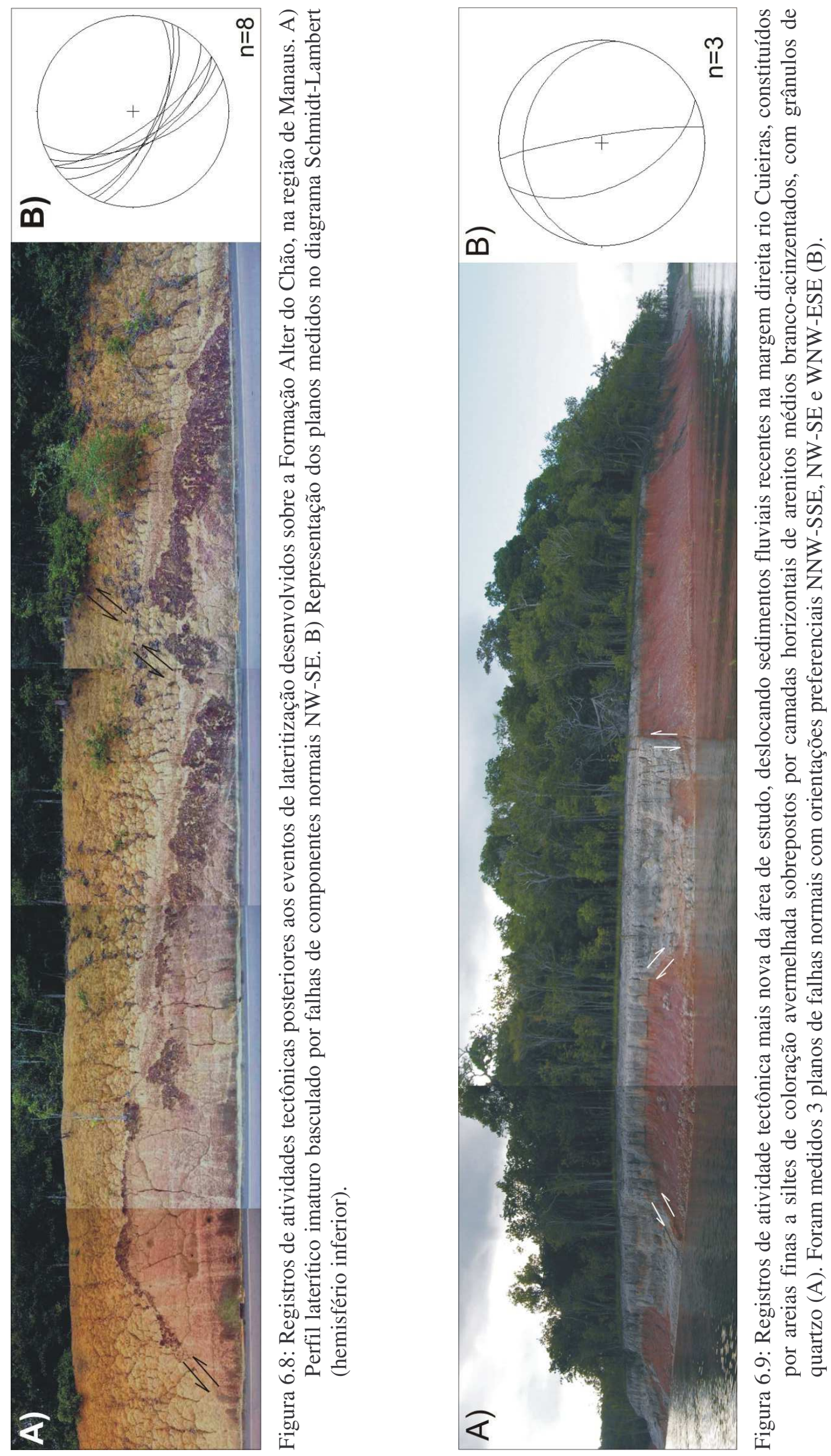


\subsubsection{SUCESSÃO DE EVENTOS TECTÔNICOS}

Os esforços identificados na área de estudo foram registrados predominantemente por estruturas rúpteis, tais como falhas, juntas e fraturas, e estão relacionados a diferentes regimes tectônico que atuaram na região de Manaus, porém todos são com natureza distensiva. Entretanto, a pouca preservação de indicadores cinemáticos importantes, como as estrias, restringe as possibilidades de definição precisa dos regimes de esforços na região.

Os registros de tectonismo sinsedimentar identificados em arenitos finos, médios e grossos, representados por laminações convolutas, slumps e falhas sindeposicionais, podem ser indicativas de processo de liqüefação local induzido por movimentações tectônicas, caracterizando uma fácies de sismitos nesta unidade, o que indica a atuação de movimentos tectônicos durante da Formação Alter do Chão. Esta atividade tectônica, penecontemporânea a uma fase de sedimentação fluvial da Formação Alter do Chão, foi responsável pelas deformações sindeposicionais e geração de falhas normais. As componentes normais e orientações predominantes E-W, variando de ENE-WSW a WNW-ESE, das falhas sindeposicionais presentes na Formação Alter do Chão, além dos poucos indicadores cinemáticos observados, são sugestivos da vigência de regime tectônico distensivo de direção geral N-S durante a deposição desta unidade. Variações locais para NE-SW na orientação indicam atuação de esforços locais.

Os conjuntos de falhas e juntas medidos no nível estratigráfico "Arenito Manaus", onde foram cadastradas a maioria da estrias neste estudo, apresentam grande diversidade de orientações das estruturas e superposições de estrias nas falhas associadas ao mesmo evento. Essas falhas pós-deposicionais de componentes normais, observadas tanto no "Arenito Manaus" como no topo da Formação Alter do Chão, possuem direção geral N-S, com variações locais para NNW-SSE, NNE-SSW, NE-SW e NW-SE e componentes normal, normal dextral e dextral normal. Elas estão associadas a um regime distensivo de natureza 
radial, de idade pós-cretáceo. Esta dedução é corroborada pela atitude média predominante das fraturas cadastradas nesta mesma unidade.

As falhas que deslocaram crostas ferruginosas de perfis lateríticos, linhas de pedras autóctones e solos lateríticos apresentam registros em grande quantidade de afloramentos e são admitidos como o terceiro evento de deformação da área de Manaus. Este evento consiste em uma fase importante na evolução tectônica da área, pois são indicativos da interrupção do processo de maturação geoquímica do perfil laterítico que ocasionou a restrição de ocorrência de perfis lateríticos ferruginosos na região de Manaus, conforme identificado por Costa (1991) e Horbe et al. (2001). Assim, as falhas que afetam os perfis lateríticos, as linhas de pedras e os solos com orientações principalmente na direção NNW-SSE a NNE-SSW, com variações NW, foram associadas a um regime distensivo E-W. As atividades tectônicas registradas na região do rio Cuieiras, responsáveis pela formação das falhas de componentes normais NW-SE que afetam os depósitos fluviais provavelmente quaternários daquela região estão associadas a este evento distensivo, de idade provavelmente pleistocena.

\section{INTEGRAÇÃO DOS RESULTADOS}

Os complexos ecossistema e biodiversidade encontrados na Amazônia são influenciados pela dinâmica dos grandes rios. Desde o processo de reversão para leste da drenagem do Amazonas no Neógeno, devido ao contínuo soerguimento dos Andes iniciado no Cretáceo (Hoorn et al. 1995, Mapes et al. 2006), o relevo tem sido modificado drasticamente. Barreiras geográficas relacionadas aos altos estruturais das bacias amazônicas teriam conferido rearranjos da rede de drenagem, induzidos em parte pelas movimentações tectônicas. A alternância climática de condições mais úmidas e secas tem propiciado o desenvolvimento de perfis lateríticos com diferentes estágios de maturidade geoquímica 
(Costa 1990, Fernandes Filho 1996, Horbe et al. 2001), que sustentam platôs desde o início do Neógeno.

No pretérito platô esculpido nas rochas da Bacia do Amazonas, que atualmente configura o conjunto topográfico I e sobre o qual se desenvolveram perfis lateríticos bauxíticos, atuava o processo erosivo que gerou a superfície $\mathrm{S} 1$, proposta por Horbe et al. (2001), e associada à Superfície Sul-Americana (Cretáceo tardio a Paleógeno). Os pulsos de movimentações tectônicas que interromperam o desenvolvimento de perfis lateríticos (Fernandes Filho 1996, Horbe et al. 2001), originaram desnivelamentos e controlaram reorganizações na rede de drenagem, foram os principais mecanismos que atuaram na remodelação deste pretérito platô. Os desnivelamentos gerados contribuíram para a intensificação dos processos denudacionais, condicionaram a formação de novas superfícies de aplainamento, as superfície S2 e S3, associadas às superfícies Velhas Inferior (OligocenoMioceno inicial) e Velhas Superior (Mioceno), respectivamente, e criaram espaços para acomodação de sedimentos coluviais.

A região esteve sob a atuação de movimentações tectônicas desde a deposição da Formação Alter do Chão, e ainda nos dias atuais apresenta zonas sismogênicas (Mioto 1993). A história evolutiva das atividades tectônicas nesta região está registrada por eventos deformacionais que afetaram sucessões sedimentares da Formação Alter do Chão, crostas ferruginosas de perfis lateríticos imaturos e produtos associados aos processos de lateritização, além de depósitos quaternários (Franzinelli \& Igreja 1990, Fernades Filho et al. 1997).

Inicialmente, um tectonismo sinsedimentar a deposição da Formação Alter do Chão, no Cretáceo tardio, está registrado pelas deformações na sucessão basal da unidade, na área de Manaus, relacionadas a esforços distensivos N-S. A esta fase possivelmente relacionada à reversão do fluxo do rio Amazonas, que foi responsável pela formação dos conjuntos de 
divisores topográficos I, II e III esculpidos sobre as rochas sedimentares da Bacia do Amazonas (Figs. 5.1A, B).

A implantação de um regime distensivo radial foi responsável pela segunda modificação no sistema de drenagem, que promoveu a secção do paleo-canal do rio Branquinho, com a captura de parte do canal pelo rio Cuieiras e formação do igarapé Tarumã Mirim (Fig 5.6), e levou a formação do compartimento topográfico $\Delta \mathrm{h}=75 \mathrm{~m}$. Novos esforços distensivos E-W foram responsáveis por nova interrupção do processo de lateritização na região.

\section{CONCLUSÕES}

A atuação dos processos geomorfogenéticos associados às atividades tectônicas foram responsáveis pelo modelado da região de Manaus, que resultou em relevo caracterizado por três compartimentos topográficos onde estão desenvolvidas as feições geomórficas: 1) o compartimento $\Delta \mathrm{h}<50 \mathrm{~m}$, que reúne terraços fluviais, terraços erosivos e planícies de inundação; 2) o compartimento $\Delta \mathrm{h}=75 \mathrm{~m}$, que abrange interflúvios tabulares dissecados com topos mais convexizados; e 3) o compartimento $\Delta \mathrm{h}>100 \mathrm{~m}$, composta por interflúvios tabulares com topos planos e presença de depressões.

Os registros sedimentares cenozóicos da área de estudo correspondem a depósitos coluviais e aluviais, distribuídos principalmente sobre a Formação Alter do Chão, na região de Manaus. Os sítios de sedimentação aluvial têm ocorrência na porção sul da área, associados às áreas de inundação do rio Amazonas e de tributários de ordem hierárquica imediatamente inferior (e.g. rios Negro e Cuieiras), aos quais estão relacionados depósitos de planície de inundação, lacustres ou de meandros abandonados (lagos tipo oxbow), todos com distribuição em faixas altimétricas menores do que 50m. A sedimentação na região de Manaus é 
predominantemente coluvial, com cascalhos e areias depositados durante fases de coluviação possivelmente desde o Plioceno-Pleistoceno, com a deposição do DCA sobre a Superfície Sul-Americana.

A denudação foi o mecanismo ativo no processo de sedimentação coluvial da região, associado aos processos de incisão de canais e a atividades tectônicas, que induziram o colapso de rochas e perfis lateríticos e impulsionaram os processos gravitacionais, favorecendo a formação de depósitos coluviais da região. O suprimento sedimentar foi proveniente de perfis lateríticos maturos e imaturos, fácies argilosas da Formação Alter do Chão, paleopavimentos residuais ou possivelmente depósitos coluviais pretéritos desenvolvidos sobre interflúvios tabulares (platôs). A deposição dos colúvios mais jovens (DCD), posteriores aos perfis ferruginosos imaturos associados à Superfície Velhas Superior, ocorreu provavelmente após a última fase de movimentação neotectônica.

Os registros de atividades tectônicas na região de Manaus permitem sugerir a ocorrência de três pulsos de esforços distensivos que vigoram desde o Cretáceo tardio, que são correlacionáveis aos esforços distensivos atuantes na Venezuela. O primeiro evento tectônico é sinsedimentar à deposição dos arenitos da Formação Alter do Chão e relacionada a esforços distensivos N-S. Subsequente, vigorou um regime distensivo radial, ao qual foram associadas as reorganizações de drenagens da região. Posteriormente, um regime de esforços distensivo E-W afetou os perfis lateríticos, linhas de pedras ferruginosas, oxissolos e sedimentos quaternários da região do rio Cuieiras.

A atuação destes movimentos tectônicos gerou escalonamentos topográficos, que favorecem a dissecação do relevo e o progressivo rebaixamento das feições geomórficas, com erosão dos topos dos interflúvios e suavização da inclinação das vertentes por processos de intemperismo, erosão e movimentos gravitacionais de massa. A este processo está associada à formação da superfície S3, relacionada à pediplanação do conjunto topográfico I. 


\section{REFERÊNCIAIS BIBLIOGRÁFICAS}

3DNATURE. STRMFill v1.00. Disponível em: http://www.3dnature.com/srtmfill.html. Acessado em junho de 2005.

Absy M.L. 1994. Dados sobre as mudanças do clima e da vegetação da Amazônia durante o Quaternário. Acta Amazonica. 10:929-938.

Albuquerque O.R. 1922. Reconhecimento dos vales do Amazonas. Bol. Serv. Geol. Min., 3:184.

Aleva G.J.J. 1989. Occurrence of stone-lines in tin-bearing areas in Belitung, Indonesia, and Rondonia, Brazil. Geo-Eco-Trop., 11:197- 203.

Aleva G.J.J. 1984. Lateritization, bauxitization and cyclic landscape development in the Guiana Shield. In: L. Jacob (ed.). Bauxite. Proc. Bauxite Symposium, A.I.M.E., Los Angeles, 142:297-318.

Almeida F.F.M. 1967. Origem e evolução da Plataforma Brasileira. Boletim Divisão de Geologia e Mineralogia. Rio de Janeiro, DNPM, n. 241, p. 1-36.

Almeida F.F.M. 1969. Diferenciação tectônica da Plataforma Brasileira. In: SBG, Cong. Bras. Geol., 23, Anais..., p. 29-46.

Almeida-Filho R. \& Miranda F.P.. 2007. Mega capture of the Rio Negro and formation of the Anavilhanas Archipelago, Central Amazônia, Brazil: Evidences in an SRTM digital elevation model. Remote Sensing of Environment, 110:387-392.

Angelier J. \& Mechler P. 1977. Sur une méthode graphique de recherche des constraintes principales également utilisable en téctonique et en seimologie: la méthode de dièdres droits. Bull. Soc. Géol. France, 7:1309-1318.

Angelier J. 1994. Fault slip analysis and paleostress reconstruction. In: P.L. Hancock (ed.) Continental deformation. Pergamon, Oxford, pp. 53-100.

Arai M. 2005. A grande elevação eustática do Mioceno: a verdadeira origem do Grupo Barreiras. In: ABEQUA, Congresso da Associação Brasileira de Estudos Quaternários, 10, Boletim de Resumos (CD-Rom).

Arnot M.J., Good T.R., Lewis J.J.M. 1997. Photogeological and image-analysis techniques for collection of large-scale outcrop data. J. Sediment. Res., 67:984-987.

Assumpção M. 1992. The regional intraplate stress field in South America. J. Geophys. Res., 97:11889-11903.

Bardossy G. \& Aleva G.J.J. 1990. Lateritic bauxites. Dev. Econ. Geol. 27, 624 p.

Barros R.S. 2004. Avaliação do Modelo Digital de Elevação do SRTM na Ortorretificação de Imagens Spot 4 Estudo de Caso: Angra dos Reis - Rj. In: SIMGEO, 1, Anais... (CDRom).

Behling H., Keim G., Irion G., Junk W., Mello J.N. 2001. Holocene environmental changes in the Central Amazon Basin inferred from Lago Calado (Brazil). Palaeogeogr., Palaeoclimatol., Palaeoecol. 173:87-101.

Bemerguy R.L. \& Costa J.B.S. 1991. Considerações sobre a evolução do sistema de drenagem da Amazônia e sua relação com o arcabouço tectônico-estrutural. Bol. Mus. Par. Emilio Goeldi, Série Ciências da Terra, 3:75-97. 
Bento A.H., Frota C.A. 1999. Mapeamento geotécnico da área urbana de Manaus em seu aspecto ambiental. In: ABGE/ABMS, Congresso Brasileiro de Geotecnia Ambiental, 4, Resumos, 1:71-77.

Bezerra P.E.L. 2003. Compartimentação morfotectônica do interflúvio Solimões - Negro. Dissertação de Mestrado, Centro de Geociências, Universidade Federal do Pará, 194 p.

Bigarella J.J. \& Mousinho M.R. 1965. Considerações a respeito dos terraços fluviais, rampas de colúvio e várzeas. Bol. Par. Geog. 16/17:153-197.

Blikra L.H. \& Nemec W. 1998. Post-glacial colluvium in western Norway depositional processes, facies and palaeoclimatic record. Sedimentology, 45:909-959.

Butt C.R.M. \& Zeegers H. 1992. Exploration geochemistry in tropical and subtropical terrains. In: G.J.S. Govett (ed.). Handbook of Exploration Geochemistry, Elsevier, v. 4, $607 \mathrm{pp}$.

Campbell Jr. K.E., Heizler M., Frailey C.D., Romero- Pittman L., Prothero D.R. 2001. Upper Cenozoic chronostratigraphy of the southwestern Amazon Basin. Geology, 29:595-598.

Caputo M.V., Rodrigues R., Vanconcelos D.N.N. 1971. Litoestratigrafia da bacia do rio Amazonas. Petrobrás -Renor. (Relatório Interno, 641 A).

Caputo M.V., Rodrigues R., Vasconcelos D.N.N. 1972. Nomenclatura estratigráfica da Bacia do Amazonas - Histórico e atualização. In: SBG, Cong. Bras. Geol., 26, Resumos, 3:3546.

Chauvel A., Boulet R., Join P., Boucquier G. 1982. Aluminum and iron oxi-hydroxide segregation in nodules of latosols developed on Tertiary sediments (Barreiras Group), near Manaus (Amazon basin). In: A.J. Melfi \& A. Carvalho (eds.). Laterisation Processes. São Paulo, pp. 507-526.

Choubert B. 1957. Essai sur la gèomorphologie de la Guyane. Mèmoire, Carte gèologique dètaillèe de la France: Dèpartement de la Guyane. Imprimerie Nationale, Paris, 43 p.

Coblentz D.D. \& Richardson R.M. 1996. Analysis of the South American intraplate stress field. J. Geophys. Res, 101:8643-8658.

Colinvaux P.A. \& De Oliveira P.E. 2001. Amazon plant diversity and climate through the Cenozoic. Palaeogeogr., Palaeoclimatol., Palaeoecol. 166:51-63.

Collinson J.D. 1996. Alluvial sediments. In: Reading H.G. (ed.). Sedimentary environments, process, fácies and stratigraphy. Blackwell Science. p. 37-81.

Colmenares L. \& Zoback M.D. 2003. Stress field and seismotectonics of northern South America. Geology, 31:721-724.

Costa A.R.A. 2002. Tecônica Cenozóica e a Movimentação Salífera na Bacia do Amazonas e suas Relações com a Geodinâmica das Placas da América do Sul, Caribe, Cocos e Nazca. Dissertação de Mestrado, Centro de Geociências, UFPA, 238p.

Costa J.B.S., Bemerguy R.L., Hasui Y., Borges M.S. 2001. Tectonics palaeogeography along the Amazon river. J. S. Am. Earth Sciences. 14:335-347.

Costa J.B.S., Bemerguy R.L., Hasui Y., Borges M.S., Ferreira Júnior C.R.P., Bezerra P.E.L., Costa M.L., Fernandes J.M.G. 1996. Neotectônica da região Amazônica: aspectos tectônicos, geomorfológicos e deposicionais. Geonomos, 4:23-24. 
Costa J.B.S., Hasui Y., Bemerguy R.L., Borges M.S., Costa A.R., Travassos W., Mioto J.A., Igreja H.L.S. 1993. Aspectos fundamentais de Neotectônica da Amazônia brasileira. In: INQUA, Simp. Inter. Quat. Amaz., FUA/INPA/UNESCO, Resumos expandidos, p.103105.

Costa M.L. 1990. Lateritos e lateritização. In: Cong. Bras. Geol., 36, Resumos, 1:404-420.

Costa M.L. 1991. Aspectos geológicos dos lateritos da Amazónia. Rev. Bras. Geoc., 21:146160.

Costa R.C.R., Filho N.T., Oliveira A.A.B. 1978. Geomorfologia. Folha SA.20 - Manaus. In: Projeto RADAMBRASIL (Levantamento de Recursos Naturais). Rio de Janeiro, MME/DNPM, 18:167-244.

CPRM. 2005. Zoneamento Ecológico - Econômico do Distrito Agropecuário da SUFRAMA. Tomo II - Meio Físico (Geologia e Recursos Minerais). Manaus, 47pp.

Crowley K.D. 1984. Filtering of depositional events and the completeness of sedimentary sequences. J. Sediment. Petrol., 54:127-136.

Cunha F.M.B. 1990. Morfologia e Neotectonismo do rio Amazonas In: SBG, Cong. Bras. Geol., 30, p. 193-210.

Cunha P.R.C., Gonzaga F.G., Coutinho L.F.C., Feijó F.J. 1994. Bacia do Amazonas. Bol. Geoc. Petrobrás. 8:47-55.

Daemon R.F. \& Contreiras J.A. 1971. Zoneamento palinológico da Bacia do Amazonas. In: SBG, Cong. Bras. Geol., 25, Resumos, p. 79-88.

Daemon R.F. 1975. Contribuição à datação da Formação Alter do Chão, Bacia do Amazonas. Rev. Bras. Geoc., 5:78-84.

Deffontaines B. \& Chorowicz J. 1991. Principles of drainage basin analysis from multisource data: application to the structural analysis of the Zaire Basin. Tectonophysics, 194:237263.

Delvaux D. 2001. The Tensor Program for paleostress reconstruction: exemples from the East African and Baikal rift zones. EUGVII Strasburg, France. Suplement $n^{\circ} 1$ to Terra Nova, Abstract...v.5, p.216.

Dino R., Silva O.B., Abrahão D. 1999. Caracterização palinológica e estratigráfica de estratos cretáceos da Formação Alter do Chão, Bacia do Amazonas. In: Simp. Cretác. Brasil, 5, Bol. Resumos. p. 557-565.

Dino R., Soares E.A.A., Riccomini C., Antonioli L., Nogueira A.C.R. 2006. Caracterização palinoestratigráfica de depósitos miocênicos da Bacia do Amazonas, região de Manacapuru, AM. In: Simp. Cretác. Brasil, 7, Bol. Resumos. p. 43.

Doblas M., Mahecha V., Hoyos M., Lopez-Ruiz J. 1997. Slickenside and fault surface kinematic indicators on active normal faults of the Alpine Betic cordilleras, Granada, Southern Spain. J. Struct. Geol. 19:159-170.

Drăgut L. \& Blaschke T. 2006. Automated classification of landform elements using objectbased image analysis. Geomorphology, 81:330-344.

EMBRAPA (Empresa Brasileira de Pesquisa Agropecuária). 1999. Sistema Brasileiro de Classificação de Solos. 412 pp.

Fernandes Filho L.A. 1996. Geologia, mineralogia, geoquímica dos lateritos de Manaus Amazonas. Dissertação de Mestrado, Centro de Geociências, UFPA, 96p. 
Fernandes Filho L.A., Costa J.B.S., Costa M.L. 1995. Bacia de Manaus: uma estrutura pullapart do Quaternário. In: Simp. Nac. Est. Tect., 5, Bol. Res. Exp. p. 425-426.

Fernandes Filho L.A., Costa M.L., Costa J.B.S. 1997. Registros neotectônicos nos lateritos de Manaus-Amazonas. Geociências, 16:9-33.

Ferrari A.L. 2001. Evolução Tectônica do Graben da Guanabara. Tese de Doutoramento, Instituto de Geociências, Universidade de São Paulo, 412p.

Forsberg B.R., Hashimoto Y., Rosenqvist A., Miranda F.P. 2000. Tectonic fault control of wetland distributions in the Central Amazon revealed by JERS-1 radar imagery. Quaternary International, 72:61-66.

Franzinelli E .1987. Quaternary sedimentation in the lower Negro River, Amazonas, Brazil. In: Cong. INQUA, 3, Ottawa, Programme with abstracts. p. 168.

Franzinelli E. \& Igreja H.L.S. 1990. Utilização do sensoriamento remoto na investigação da área do baixo Rio Negro e Grande Manaus. In: Simp. Bras. Sens. Rem., 6, Anais..., 3:641-648.

Franzinelli E. \& Igreja H.L.S. 2002. Modern sedimentation in the Lower Negro River, Amazonas State, Brazil. Geomorphology, 44:259-271.

Franzinelli E. \& Latrubesse E. 1993. Neotectonic in the central part of the Amazon Basin. Bull. INQUA Neotecton. Comm., 16, p. 10-13.

Franzinelli E. \& Ori G.G. 1988. Mecanismo de preenchimento dos paleovales quaternários na Amazônia. In: Cong. Latino-Americano Geologia, 7, Belém, Anais..., p. 399-407.

Franzinelli E. \& Piuci J. 1988. Evidências de neotectonismo na Bacia Amazônica. In: Cong. Latino-Americano Geologia, 7, Anais..., 1:80-90.

Giral-Kacmarcik S., Nahon D.B., Girard J.P., Lucas Y., Abel L.J. 1998. Oxigene isotope geochemistry of kaolinite in laterite-forming processes, Manaus, Amazonas, Brazil. Geochimica et Cosmochimica Acta, 62:1865-1879.

Golts S. \& Rosenthal E. 1993. A morphotectonic map of the northern Arava in Israel, derived from isobases lines. Geomorphology. 7:305-315.

Grohmann C.H., Riccomini C., Alves F.M. 2007. SRTM-based morphotectonic analysis of the Poços de Caldas Alkaline Massif, southeastern Brazil. Comput. Geosci, 33:10-19.

Hancock P.L. \& Engelder T. 1989. Neotectonic joints. GSA Bull. 101:1197-1208.

Harms J.C., Southard J.B., Walker R.G. 1982. Structures and sequences in clastic rocks. Soc. Econ. Paleont. Miner. 249p. (Short course, 9).

Hennig T.A., Kretsch J.L., Pessagno C.J., Salamonowicz P.H., Stein W.L. 2001. The Shuttle Radar Topography Mission. In: C.Y. Westort (ed.). DEM 2001, LNCS 2181, SpringerVerlag. p. 65-77.

Hiruma S. \& Riccomini C. 1999. Análise morfométrica em neotectônica: o exemplo do Planalto de Campos do Jordão, SP. Rev. Inst. Geol., 20:5-19.

Hiruma S.T. 1999. Neotectônica do planalto de campos do Jordão, SP. Dissertação de Mestrado, Instituto de Geociências, Universidade de São Paulo. 102p.

Hoorn C. 1994. An environmental reconstruction of the palaeo-Amazon-River system (Middle to Late Miocene NW Amazonia). Palaeogeogr., Palaeoclimatol., Palaeoecol., 112:187-238. 
Hoorn C., Guerrero J., Sarmiento G., Lorente M. 1995. Andean tectonics as a cause for a changing drainage patterns in Miocene northern South America. Geology, 23:237-240.

Horbe A.M.C.\& Costa M.L. 1999. Relações genéticas entre latossolos e crostas lateríticas aluminosas e alumino-ferruginosas na região de Paragominas, Pará. Rev. Bras. Geoc., 29:497-504.

Horbe A.M.C.\& Costa M.L. 2004. Lateritic crusts and related soils in eastern Brazilian Amazonia. Geoderma, 126:225-239.

Horbe A.M.C., Costa M.L., Fernandes Filho L.A., Oliveira Z.C. 1997. Caracterização de latossolos desenvolvidos sobre crostas alumino-ferruginosas lateríticas com base na mineralogia e elementos traço. In: SBGq, Cong. Bras. Geoq., 6, Resumos, 2:547-549.

Horbe A.M.C., Horbe M.A., Suguio K. 2003. Origem dos depósitos de areias brancas no nordeste do Amazonas. Rev. Bras. Geoc., 33:41-50.

Horbe A.M.C., Nogueira A.C.R., Horbe M.A., Costa M.L., Suguio K. 2001. A lateritização na gênese das superfícies de aplanamento da região de Presidente Figueiredo-Balbina, nordeste do Amazonas. In: J. Reis \& M.A.S. Monteiro (coord.). Contribuições à geologia da Amazônia. 2:148-176.

Horbe A.M.C., Nogueira A.C.R., Rozo J.M. 2004. Evidências de dois episódios de lateritização na região de Novo Remanso-AM. In: SBG, Cong. Bras. Geol., 42, Anais... (CD-Rom).

Horton R.E. 1932. Drainage basin characteristics. Transactions American Geophysical Union, 13:350-361.

Horton R.E. 1945. Erosional development of streams and their drainage basins: hydrophysical approach to quantitative morphology. GSA Bull., 56:275-370.

Howard A.D. 1967. Drainage analysis in geologic interpretation: a summation. Am. Assoc. Petrol. Geol. Bull., 51:2246-2259.

Irion G. 1984. Sedimentation and sediments of Amazonian rivers and evolution of the Amazonian landscape since Pliocene times. In: H. Sioli (ed.). The Amazon: limnology and landscape ecology of a mighty tropical river and its basin. Dordrecht, W. Junk Publishers, pp. 201-214.

Irion G., Muller J., Mello J.N., Junk W.J. 1995. Quaternary geology of the Amazonian lowland. Geo-Marine Letters, 15:172-178.

IUGS (International Union of Geological Sciences). 2007.International Stratigraphic Chart. Disponível em http://www.stratigraphy.org/cheu.pdf. Acessado em setembro de 2007.

Jianjun H., Mukang H., Ollier C.D. 1997. A morphometric method to determine neotectonic activy of the Wheine basin in northwerstern China. Episodes, 20:95-99.

Johnson D.L. 1990. Biomantle evolution and the redistribution of earth materials and artifacts. Soil Science, 149:84-102.

Johnson M.J. \& Meade R.H. 1990. Chemical weathering of fluvial sediments during alluvial storage: the Macuapanin Island point bar, Solimões river, Brazil. J. Sed. Petrol., 60:827842.

King L.C. 1956. A geomorfologia do Brasil Oriental. Rev. Bras. Geogr., 18:147-265.

King L.C. 1964. Cyclic denudation in Suriname. Int. Rept. Geol. Mijnb Dienst Suriname. 12p. 
Kistler P. 1954. Historical resume of the Amazon Basin. Relatório Interno 104-A (inédito). PETROBRAS/RENOR, Belém.

Kotschoubey B. \& Truckenbrodt W. 1981. Evolução poligenética das bauxitas do distrito de Paragominas-Açailândia (Estados do Pará e Maranhão). Rev. Bras. Geoc., 11:193-202.

Latrubesse E.M. \& Franzinelli E. 2002. The Holocene alluvial plain of the midle Amazon River, Brazil. Geomorphology, 44:241-257.

Latrubesse E.M., Rossi A., Franzinelli E. 2000. Geomorphology of the Pacaás Novo range, southeastern Amazonia, Brazil: one example of the importance of geomorphological evidence to reconstruct Quaternary paleoenvironmental scenarios in Amazonia. Rev. Bras. Geoc., 30:517-521.

Lucas Y., Kolbisek B., Chauvel A. 1989. Structure, genesis and present evolution of amazonian bauxites developed on sediments. In: Intern. Cong. ICSOBA, 6, Anais..., 22:81-94.

Maia R.G., Godoy H.K., Iamagutti H.S., Moura P.A., Costa F.S.F., Holanda M.A., Costa J.A. 1977. Projeto Carvão no Alto Solimões. Relatório Final. Manaus, DNPM/CPRM, 137p.

Mapes R.W., Nogueira A.C.R., Coleman D.S., Vega A.M.L. 2006. Evidence for a continent scale drainage inversion in the Amazon Basin since the Late Cretaceous. In: GSA, Philadelphia Annual Meeting. Disponível em http://gsa.confex.com/gsa/2006AM/ finalprogram/abstract_113025.htm. Acessado em outubro de 2006.

McFarlane M.J. 1976. Laterite and Landscape. Academic Press, London, 151pp.

Meis M.R., Miranda L.H.G., Fernandes N.F. 1982. Desnivelamento de altitude como parâmetro para a compartimentação do relevo: bacia do médio-baixo Paraíba do Sul. In: SBG, Cong. Bras. Geol., 32, Resumos, 4:1489-1509.

Meis M.R.M. 1971. Upper Quaternary process of the middle Amazon area. GSA Bull. 82:1073-1078.

Mello C.L. 1997. Sedimentação e tectônica cenozóicas no Médio Vale do Rio Doce (MG, sudeste do Brasil) e suas implicações na evolução de um sistema de lagos. Tese de Doutoramento, Instituto de Geociências, USP. 275p.

Mertes L., Dunne T., Martinelli L. 1996. Channel-floodplain geomorphology along the Solimões Amazon river, Brazil. GSA Bull., 108:1089-1107.

Miall A.D. 1992. Alluvial Deposits. In: R.G. Walker\& N.P. James (eds). Facies Models Response to Sea Level Change. Geological Association of Canada. Geotext1. pp. 119142.

Mioto J.A. 1993. Sismicidade e zonas sismogênicas do Brasil. Tese de Doutoramento. Instituto de Geociências e Ciências Exatas, UNESP, vol. 1, 276p.

Modenesi-Gauttieri M.C., Hiruma S., Riccomini C. 2002. Morphotectonics of a high plateau on the northwestern flank of the Continental Rift of southeastern Brazil. Geomorphology. 43:257-271.

Molton L.C.B. 1991. The Amazonia and the global climate. Bol. Geoc. 8:15-23.

Mörner N.A. 1989. Paleoseismicity and neotectonics. Bull. INQUA Neotectonics Commission, n. $12,104 \mathrm{p}$.

Moura P. 1938. Geologia do Baixo Amazonas. Bol. Serv. Geol. Miner. DNPM, Rio de Janeiro, 91:1-50. 
Nahon D. \& Tardy Y. 1992. The ferruginous laterite. In: G.J.S. Govett (ed.). Handbook of Exploration Geochemistry, Elsevier, 4:41-78.

Nascimento D.A., Mauro C.A., Garcia M.G.L. 1976. Geomorfologia. Folha SA.21- Santarém. In: Projeto Radambrasil (Levantamento de Recursos Naturais). MME/DNPM, Rio de Janeiro, 10:131-181.

Nogueira A.C.R. \& Sarges R.R. 2001. Characterization and genesis of waterfalls of the Presidente Figueiredo region, Northeast State of Amazonas, Brazil. An. Acad. Bras. Ciênc., 73:287-301.

Nogueira A.C.R., Horbe A.M.C., Paz J.D.S., Motta M.B., Rozo J.M.G. 2006. O Neógeno da Amazônia Ocidental. In: SBG/Norte, Simp. Geol. Amaz., 9, Anais... (CD-Rom).

Nogueira A.C.R., Vieira L.C., Suguio K. 1999. Paleossolos da Formação Alter do Chão, Cretáceo-Terciário da Bacia do Amazonas, regiões de Presidente Figueiredo e Manaus. In: Simpósio sobre o Cretáceo do Brasil, 5, Boletim de resumos expandidos, 1:261-266.

Nortcliff S. 1989. A review of soil and soil-related constraints to development in Amazonia. Applied Geography, 9:147-160.

Nye, P.H. 1954. Some soil-forming processes in the humid tropics: I. A field study of a catena in the West African forest. J. Soil Science, 5:7-21.

Oliveira A.I. \& Leonardos O.H. 1943. Geologia do Brasil. 2ed. Serviço de Informação Agrícola, Rio de Janeiro, 813pp.

Parizek E.J. \& Woodruff J.F. 1957. Description and origin of stone layers in soils of the southeastern states. J. Geology, 65:24-34.

Pereira R., Carvalho M.A., Mendonça Filho J.G., Azevedo D.A., Carvalho I.S. 2006. Ocorrência de esporos de fungos preservados em âmbar cretácico da Bacia do Amazonas, Formação Alter do Chão. In: Simp. Cretác. Brasil, 7, Bol. Resumos. p. 101.

Petit J.P. 1987. Criteria for the sense of movement on faults surfaces in brittle rocks. J. Struct. Geol., 9:597-608.

Pollack H.R. 1983. Land surfaces and lateritization in Suriname. In: Melfi, A.J. \& Carvalho, A. (eds.), Proc. 2nd Int. Semin. on Lateritization Processes, pp. 295-308.

Price L.I. 1960. Dentes de therapoda num testemunho de sonda no estado do Amazonas, $A n$. Acad. Bras. Ciênc., 32:79-84.

Riccomini C. \& Assumpção M. 1999. Quaternary tectonics in Brazil. Episodes, 22:221-225.

Riccomini R. \& Soares E.A.A. 2004. Sismitos holocênicos em baixos terraços do Rio Solimões, Amazonas. In: SBG, Cong. Bras. Geol., 42, Anais... (CD-Rom).

Richardson R.M. \& Coblentz D.D. 1994. Stress modeling in the Andes: Constraints on the South American intraplate stress magnitudes. J. Geophys. Res., 99:22015-22026.

Roddaz M., Baby P., Brusset S., Hermoza W., Darrozes J.M. 2005. Forebulge dynamics and environmental control in Western Amazonia: The case study of the Arch of Iquitos (Peru). Tectonophysics, 399:87-108.

Rossetti D.F., Góes A.M., Santos Júnior A.E.A., Paz J.D.S. 2007. Reconstrução de Paisagens Pós-Miocênicas na Amazônia Brasileira. In: A.L.K.M. Albernaz. (org.). Conservação da Várzea: Identificação e Caracterização de Regiões Biogeográficas. 1 ed. ManausProvarzea/IBAMA, 1:29-64. 
Rossetti D.F. \& Netto R.G. 2006. First evidence of marine influence in the Cretaceous of tha Amazonas Basin, Brazil. Cretaceous Research, 27: 513-528.

Rossetti D.F., Toledo P.M., Góes A.M. 2005. New geological framework for Western Amazonia (Brazil) and implications for biogeography and evolution. Quaternary Research, 63:78-89.

Rozo J.M.G., Nogueira A.C.R., Horbe A.M.C., Carvalho A.S. 2005. Depósitos Neógenos da Bacia do Amazonas. In: J. Reis, \& M.A.S. Monteiro (coord.). Contribuições à geologia da Amazônia. 4:116-123.

Ruhe R.V. 1959. Stone lines in soils. Soil Science, 84:223-231.

Santos J.O.S. 1975. A inaplicabilidade do termo "Barreiras" na geologia da Amazônia Central e Ocidental. Relatório Interno, CPRM, Manaus. 20p.

Santos J.O.S., Moreira A.S., Pessoa M.R., Oliveira J.R., Malouf R.F., Veiga Jr. J.P., Nascimento J.O. 1974. Projeto Norte da Amazônia, Domínio Baixo Rio Negro. Geologia da Folha NA. 20-Z. Relatório final. DNPM/CPRM, Manaus, v.15, p.50-54.

Santos J.O.S., Souza M.M., Prazeres W.V., Silva S.L., Barreto E.L., Pessoa M.R. 1974. Projeto Norte da Amazônia. Domínio Baixo Rio Negro. Relatório Final. Manaus, CPRM, v. 2-A, p. 57-135.

Santos P.R.A. 2005. Avaliação da precisão vertical dos modelos SRTM em diferentes escalas: um estudo de caso na Amazônia. Dissertação de Mestrado, Instituto Militar de Engenharia, Rio de Janeiro. 108p.

Santos P.R.A., Gaboardi C., Oliveira L.C. 2005. Avaliação da precisão vertical dos modelos SRTM para a Amazônia. In: INPE, Simpósio Brasileiro de Sensoriamento Remoto, 12, Anais..., p. 4473-4480.

Schellmann W. 1979. Considerations on the definition and classification of laterites. In: Intern. Seminar on Laterization Processes, 1, Proceedings..., p.1-10.

Schobbenhaus C. \& Campos D.A. 1984. A Evolução da plataforma sul-americana no Brasil e suas principais concentrações minerais. In: C. Schobbenhaus, D.A. Campos, G.R. Derze, H.E. Asmus (org.) Geologia do Brasil. Ed. Comemorativa do Cinqüentenário. DNPM, Brasília, pp. 9-49.

Schumm S.A. 1999. Causes and controls of channel incision. In: S.E. Darby \& A. Simon (eds.). Incised river channels: processes, forms, engineering and management. John Wiley, New York, pp. 19-33.

Selby M.J. 1994. Hillslope sediment transport and deposition. In: K. Pye (ed.). Sediment transport and depositional process. Blackwell Scientific Publications, Oxford, pp. 61-83.

Silva C.L. 2005. Análise tectônica cenozóica da região de Manaus e adjacências. Tese de Doutoramento, Instituto de Geociências e Ciências Exatas, UNESP, 278p.

Silva T.M., Peixoto M.N.O., Moura J.R.S. 1995. Relief compartiments and distribuition of Quaternary depositional features in the Brazilian Southeastern Plateau. The European Geographer, 9:172-181.

Silva T.M. 2002. A Estruturação Geomorfológica do Planalto Atlântico no Estado do Rio de Janeiro. Tese de Doutoramento, Departamento de Geografia/Instituto de Geociências. UFRJ, 265p. 
Simon A., Curini A., Darby S.E., Langendoen E.J. 1999. Streambank mechanics and the role of bank and near-bank processes in incised channels. In: S.E. Darby \& A. Simon (eds.). Incised Channels: Processes, Forms, Engineering Management, John Wiley, New York, pp. 123-152.

Small R.J. 1986. The study of landforms. 2nd. Edition. University Cambridge Press. 502pp.

Soares E.A.A. 2007. Depósitos pleistocenos da região de confluência dos rios Negro e Solimões, Amazonas. Tese de Doutoramento, Instituto de Geociências, USP, 205p.

Soares E.A.A. \& Riccomini C. 2003. Neotectônica e sedimentação quaternária na região do Baixo Rio Negro, Amazonas. In: SBG/Norte, Simp. Geol. Amaz., 8, Resumos (CD-Rom).

Soil Survey Staff. 1975. Soil Taxonomy, Washington DC. US Departament of Agriculture. Handbook 436, 754p.

Sombroek W.G. 1966. Amazon, soils. A reconnaissance of the soils of the Brazilian Amazon region. Wageningen, Centre for Agr. Publ. Document, 292p.

Souza M.M. 1974. Perfil Geológico da BR-174 (Manaus-Boa Vista) no trecho Manaus-Serra do Abonari. In: SBG, Cong. Bras. Geol., 28, 2:175-186.

Sternberg H.O. 1950. Vales tectônicos na planície amazônica? Rev. Bras. Geogr., 12:3-26.

Sternberg H.O. 1955. Séismicité et morphologie en Amazonie Brésilienne. Annales de Géographie. Bull. Société de Géographie. n. 342, p. 97-105.

Strahler A.N. 1952. Hypsometric (area-atitude) analysis of erosional topography. GSA Bull., 63:1117-1142.

Summerfield M.A. 1991. Global Geomorphology: An introduction to the study of landforms. New York, Longman Scientific \& Technical. 537pp.

Tardy Y. \& Roquin C. 1998. Dérive des Continents, Paleoclimat et altérations tropicales. BRGM. 473pp.

Tardy Y. 1993. Pétrologie des laterites et des soils tropicaux. Masson, Paris. 459 pp.

Tardy Y., Mortatti J., Probst J.L. 1995. Erosion chimique et mècanique dans le bassin de l'Amazone. Evaluation du ruissèllement par la méthode dite des réservoirs à contribution variable mais à composition constante. C.R. Acad. Sci., 320:945-952.

Terrainmap. 2003. Using BLACKART to repair SRTM and ASTER DEMs. Disponível em http://www.terrainmap.org/rm38.html. Acessado em junho de 2005.

Travassos W.A.S. \& Barbosa Filho C.M. 1990. Tectonismo Terciário na área do rio Tapajós, Bacia do Amazonas. Bol. Geoc. Petrobrás. 4:221-340.

Tricart J. 1977. Aperçu sur le Quaternaire Amazonien. Annais de Geographie, 473:1-54.

Trindade R.I.F., Horbe A.M.C., Peixoto S.F. 2006. Paleomagnetismo de crostas lateríticas da região Amazônica: dados preliminares e implicações cronológicas. In: SBG, Cong. Bras. Geol., 42, Anais..., p. 136.

Truckenbrodt W. \& Kotschoubey B. 1981. Argila de Belterra - cobertura terciária das bauxitas amazônicas. Rev. Bras. Geoc., 11: 203-208.

Tynney E.R. 1962. The process of channel degradation. J. Geophysical Research, 67:14751480. 
UFAM. 2004. Geologia do Amazonas. In: A.M.C. Horbe (coord.). Avaliação dos parâmetros geológicos, pedológicos e geomorfológicos como subsídio para a recuperação de áreas degradadas na Província Petrolífera do Urucu. Relatório interno. UFAM/CTPETROCNPq. 54p.

USGS. 2003. DEM 3'’. Disponível em http://seamless.usgs.gov. Acessado em setembro de 2003.

Valeriano M.M. 2004. Modelo Digital de Elevação com dados STRM disponíveis para a América do Sul. Relatório INPE-10550-RPQ/756, INPE, São José dos campos, 71p.

Valeriano M.M., Kuplich T.M., Storino M., Amaral B.D., Mendes Jr. J.N., Lima D.J. 2006. Modeling small watersheds in Brazilian Amazonia with Shuttle Radar Topographic Mission-90m data. Comput. Geosci, 32:1169-1181.

Valeton I. 1999. Saprolite-bauxite facies of ferralitic duricrusts on paleosurfaces of former Pangaea. In: T. Médard \& R. Simon-Coinçon (eds). Palaeoweathering, palaeosurfaces and related continental deposits. IAS, Special Publication, 27, p. 153-188.

Van der Hammen T. \& Absy M.L. 1994. Amazonia during the Last Glacial. Palaeogeogr., Palaeoclimatol., Palaeoecol., 109:247-261.

Vieira L.C. 1999. Depósitos fluviais da Formação Alter do Chão, Cretáceo-Terciário da Bacia do Amazonas, Ponta Negra, Manaus. Relatório Final de PIBIC, FUA/DEGEO/CNPq. 53p.

Walker R.G. 1992. Facies, facies models and modern stratigrahic concepts. In: R.G. Walker \& N.P. James (eds.). Facies Models - Response to Sea Level Change. Geological Association of Canada. Geotext1. pp. 1-14.

Wanderley Filho J.R. 1991. Evolução estrutural da bacia do Amazonas e sua relação com o embasamento. Dissertação de Mestrado, Centro de Geociências, UFPA. 125p.

Zalán P.V. 1986. A tectônica transcorrente na exploração do petróleo: uma revisão. Rev. Bras. Geoc., 16:245-257.

Zoback M.L., Zoback M.D., Adams J., Assumpção M., Bell, S., Bergman E.A., Blümling P., Brereton N.R., Denham D., Ding J., Fuchs K., Gay N., Gregersen S., Gupta H.K., Gvishiani A., Jacob K., Klein R., Knoll P., Magee M., Mercier J.L., Müller B.C., Paquin C., Rajendran K., Stephansson O., Suarez G., Suter M., Udias A., Xu Z.H., Zhinzhin M. 1989. Global patterns of tectonics stress. Nature, 341:291-298. 